\title{
Schiff's Bases and Crown Ethers as Supramolecular Sensing Materials in the Construction of Potentiometric Membrane Sensors
}

\author{
Farnoush Faridbod ${ }^{1}$, Mohammad Reza Ganjali ${ }^{1, *}$, Rassoul Dinarvand ${ }^{2}$, Parviz Norouzi ${ }^{1}$ and \\ Siavash Riahi ${ }^{3}$ \\ ${ }^{1}$ Center of Excellence in Electrochemistry, Faculty of Chemistry, University of Tehran, Tehran, Iran \\ ${ }^{2}$ Medical Nanotechnology Research Centre, Medical Sciences/University of Tehran, Tehran, P.O. \\ Box 14155-6451, Iran \\ ${ }^{3}$ Institute of Petroleum Engineering, Faculty of Engineering, University of Tehran, Tehran, P.O. Box \\ 14155-6455, Iran
}

* Author to whom correspondence should be addressed; E-mail: ganjali@khayam.ut.ac.ir

Received: 31 December 2007 / Accepted: 22 February 2008 / Published: 11 March 2008

\begin{abstract}
Ionophore incorporated PVC membrane sensors are well-established analytical tools routinely used for the selective and direct measurement of a wide variety of different ions in complex biological and environmental samples. Potentiometric sensors have some outstanding advantages including simple design and operation, wide linear dynamic range, relatively fast response and rational selectivity. The vital component of such plasticized PVC members is the ionophore involved, defining the selectivity of the electrodes' complex formation. Molecular recognition causes the formation of many different supramolecules. Different types of supramolecules, like calixarenes, cyclodextrins and podands, have been used as a sensing material in the construction of ion selective sensors. Schiff's bases and crown ethers, which feature prominently in supramolecular chemistry, can be used as sensing materials in the construction of potentiometric ion selective electrodes. Up to now, more than 200 potentiometric membrane sensors for cations and anions based on Schiff's bases and crown ethers have been reported. In this review cation binding and anion complexes will be described. Liquid membrane sensors based on Schiff's bases and crown ethers will then be discussed.
\end{abstract}


Keywords: Supramolecule, Potentiometric membrane, Sensor, Ion Selective Electrode, Schiff's Base, Crown Ether

\section{Introduction}

From a color change in a flask to highly sophisticated biological mechanisms, every action that occurs around us is the result of chemical reactions and physicochemical interactions occurring in various combinations. These reactions and interactions often seem to occur randomly, but this is rarely true. They often occur between selected partners-especially when the reactions and interactions occur in a highly organized system such as those found in biological settings-as the molecule recognizes the best (or better) partner. This mechanism is called "molecular recognition".

Supramolecular chemistry, which is defined as the chemistry of molecular systems beyond individual molecules and which is highly dependant on the phenomenon of molecular recognition due to a host-guest relationship, was first established more than one hundred years ago. Alfred Werner was the first to introduce the concept of coordination chemistry [1]. The so-called "lock and key" concept in the study of the enzyme interactions, coined by Emil Fischer, can be regarded as a major concept associated with molecular recognition [2,3]. Molecular assembly and host-guest chemistries were later integrated into the individual concept of supramolecular chemistry by Lehn. This has helped elaborate the close relationship between this field and the complex supermolecular species, which are formed due to the effect of intermolecular forces on more than one chemical species, holding them together. It should be stated that the functionality of a supermolecule is beyond a simple summation of those of its individual components [3]. Many new novel compounds with high selectivities for ion or molecule separation, transport and catalytic purposes have been developed by scientists who have been active in different branches of chemistry.

\section{Principle of Potentiometric Membrane Sensors}

Since the 1930s, potentiometric membrane sensors have found great practical applicability in different fields. The response mechanism of these sensors is based on the measurement of a potential under a zero current regime or a under a low electrical current flow. Potentiometric membrane sensors, which have been designed based on molecular recognition, contain a molecule that selectively recognizes another target species through various molecular interactions. As it is widely known, potentiometric electrodes possess as advantages the direct, simple, rapid, inexpensive and selective detection of ionic activities. The selectivity of these sensors stems from the highly selective interactions between the membrane material and the target species [4].

The most prominent ingredient of a potentiometric ion-selective electrode (ISE) is, by drfinition, its selective membrane. Once an ion can pass through the boundary between the organic phase of the membrane and the internal and the sample solution, an electrochemical equilibrium will be established, under which it is probable that different potentials are developed in the two aqueous phases. So, in case the ionophore can exchange only one certain target ion, the potential difference between the phases will reflect the activities of the target ion in the two solution and the membrane phases. 
If a membrane separates two solutions of different ionic activities $\mathrm{a}_{1}$ and $\mathrm{a}_{2}$, the so-called Nernst equation is known to govern the potential difference (E) across the membrane:

$$
E=\frac{R T}{z F} \ln \left(\frac{a_{2}}{a_{1}}\right)
$$

If $\mathrm{a}_{1}$ is constant, only $\mathrm{a}_{2}=\mathrm{a}_{\mathrm{x}}$ can be related to the measured potential (E). Under ideal conditions, it is only the activity of the target ion in the phases that affects the potential. The Nernst equation describes the relation between the activity and the electrochemical potential:

$$
E=\frac{R T}{z_{x} F} \ln \left(\frac{a_{x}}{a_{1}}\right) \cong E=\text { Const. }+S \cdot \log \left(a_{x}\right)
$$

where $z_{\mathrm{x}}$ is the charge of the target ion and S equals $59.16 / \mathrm{z}_{\mathrm{x}}[\mathrm{mV}]$ at $298 \mathrm{~K}$.

Using two identical reference electrodes in the solutions on both sides of the sensing element, " $\mathrm{E}$ or the electromotive force (EMF)” can be easily measured. In practice, this parameter is measured between the ISE (already containing an internal reference electrode) and an external reference electrode in the sample solution. One should keep in mind that this is a zero current measurement that is performed under equilibrium conditions in which the transfer rate of ions from the solution to the membrane is equal to that from the membrane to the solution. It is assumed that under ideal conditions, other ions which cannot permeate the membrane will have no considerable effect on the potential difference.

The activity of the target ion governs the potential of such a membrane which is also governed to some extent by the activity of the interfering ions under actual conditions. If the activity of a hypothetical interfering ion, $\mathrm{Y}$, with a charge of $\mathrm{z}_{\mathrm{y}}$, is $\mathrm{a}_{\mathrm{y}}$, and if the selectivity coefficient of the sensor to this ion is $\mathrm{K}_{\mathrm{xy}}$, the effect of interfering ion on the measured potential difference is considered by the so-called Nikolski-Eisenman equation:

$$
E=\text { Const. }+S \cdot \log \left(a_{x}\right)+\frac{z_{x}}{z_{y}} \cdot \log \left(K_{x y} \cdot a_{y}\right)
$$

\subsection{Polymeric membrane}

Any polymeric membrane ISE consists of components, the nature and the amounts of which greatly affect the nature and the characteristics of the sensor. These components include the polymeric matrix, the ionophore, the membrane solvent mediator and the ionic additive.

The first polymeric ISE membranes, in which the polymer was considered to provide the required physical properties, like elasticity and mechanical stability, consisted of valinomycin as the ionophore, which was incorporated into silicone rubber [5] or PVC [6], without the addition of lipophilic ionic sites [7-10]. There are other polymers which can be used instead of PVC in the membrane construction. Soft polyurethanes with a low content of crystalline units [11], silicone rubber [5], poly(vinylidene chloride) [12] and polysiloxanes [13] can also be used as the matrix.

Membrane solvents (plasticizers) are used to increase the plasticity of membrane, which is required to give a homogeneous organic phase. This ingredient also affects the selectivity behavior of the ISE membrane. In the case of ligand-free ISE membranes or those based on an ion exchanger, incapable of 
specific interactions with a target ion, what governs the selectivities is the difference between the standard free energies of the ions in the aqueous and the organic phases.

Such selectivity trends are always the same as the so-called Hofmeister series, which for some cations and anions agrees with those of the free hydration energies of the ions. A plasticizer change from the polar $o$-NPOE or nitrobenzene (NB) to the apolar dibutyl phthalate (DBP), for example, is reported to reduce the $\mathrm{M}^{2+}$-selectivity of the ISE with the ionophore 2,3,8,9-tetraazacyclododeca-1, 3,7,9-tetraene [14]. This is known to be due to the polarity of the plasticizer, which can be estimated from the interaction of the charged species with a continuum of the given dielectric constant (Born model) [15]. More polar solvents prefer divalent over monovalent ions. The nature of the plasticizer also strongly influences the measuring range of the ion-selective sensors, too. Another factor, highly influenced by the membrane solvent, is the formation of the ion-pairs. The amount of ion-pairs formed between the complexed ions and the lipophilic counter ions, which is known to influence the slope of the response curve, is predicted to be negligible in the polar membranes, while this is significant in the case of non-polar membranes. For example, where the $\mathrm{M}^{2+}$ cations associate with the $\mathrm{X}^{-}$anions, so that the $\mathrm{MX}^{+}$monovalent species predominantly takes part in the phase transfer equilibrium [16] and/or occurs in the membrane, a characteristic slope for a typical monovalent ion will be expected. Plasticizers which can be potentially used in potentiometric membrane are as follows: Benzyl acetate (BA), bis(2-hydroxyethyl) phthalate (BEHP), bis(1-butylpentyl) adipate (BBPA), bis(2-ethylhexyl) adipate (DOA), bis(2-ethylhexyl) phthalate (dioctyl phthalate) (DOP), bis(2-ethylhexyl) sebacate (BEHS), bis(n-octyl) sebacate (DOS), dibenzyl ether (DBE), dibutyl phthalates (DBP), dibutyl sebacate (DBS), didecyl phthalate (DDP), didecyl sebacate (DDS), (R, R)-2,3-dimethoxysuccinic acid bis(1-butylpentyl) ester (DMSNE), ethyldidecyloctadecylammonium nitrate (EDOA), 2-fluorophenyl 2-nitrophenyl ether (FNDPE), 2-nitrophenyl phenyl ether (o-NPPE), 2-nitrophenyl octyl ether (o-NPOE) and tri- $n$-butyl phosphate (TBP).

The first example of the application of an ionic additive reported was that of a tetraphenyl borate salt. This was added to the membranes of a cation-selective electrode to reduce the anionic interference, observed in the presence of lipophilic anions like thiocyanate [17]. This also leads to a lowering of the electrical resistance of the membrane, which is of special importance in the case of microelectrodes [18]. The ionic additives are also ion exchangers having the ability to induce selective responses in the absence of sufficient ionophore amounts. The concentration of these species must, hence, be adjusted carefully [19].

The ionophore or the membrane-active recognition element can be an ion exchanger or a neutral macrocyclic compound, having molecule-sized dimensions and containing cavities or semi-cavity to surround the target ions [20,21]. The ionophore, or the membrane-active recognition element, which is the most important component of the membrane will be discussed later.

\section{Cation-Binding Ionophores}

Cation recognition has developed very fast because it was based on a mixture of the wellestablished coordination geometry of most cationic species and the high binding energies resulting from the ion-dipole interactions. This also led to the development of the supramolecular chemistry, 
due to the fact that many of the fundamental concepts of this field are derived from studies on cation recognition.

The selectivity patterns of ISEs can be regarded to be the result of the different binding strengths of ionophores and the tested ions. Phase transfer of aqueous ions in and out of an organic ISE membrane is necessary for the classic behavior of ISEs, during which the interaction of the ions with the ionophore becomes possible. The ion transfer process will be controlled by the lipophilicity of the ions in case the ionophore does not have any selective tendencies for any of the ionic species [22]. This means ions of higher lipophilicity will cause larger response [23,24] which leads to the so called Hofmeister [25] selectivity pattern, merely based on the lipophilicity of the ions, which can be demonstrated for cations and anions as follows:

$$
\mathrm{Cs}^{+}>\mathrm{Ag}^{+}>\mathrm{K}^{+}>\mathrm{NH}_{4}^{+}>\mathrm{Na}^{+}>\mathrm{Li}^{+}>\mathrm{Ca}^{2+}>\mathrm{Pb}^{2+}>\mathrm{Cu}^{2+}
$$

The equivalent pattern for the anions is:

$$
\begin{aligned}
& \mathrm{ClO}_{4}{ }^{-}>\mathrm{SCN}^{-}>\mathrm{I}^{-}>\mathrm{C}_{6} \mathrm{H}_{4}(\mathrm{OH}) \mathrm{COO}^{-}>\mathrm{NO}_{3}{ }^{-}>\mathrm{Br}^{-}>\mathrm{NO}_{2}{ }^{-}>\mathrm{Cl}^{-}>\mathrm{HSO}_{3}{ }^{-}>\mathrm{CH}_{3} \mathrm{COO}^{-}>\mathrm{SO}_{4}{ }^{2-}> \\
& \mathrm{HPO}_{4}{ }^{2-}
\end{aligned}
$$

These patterns are called the Hofmeister series [25]. One should also note that the presence of a selective ionophore in the ISE membrane leads to decreases in the total free energy required for the transfer of the ionophore-ion complex into the organic phase. So, the stronger the binding of the ionophore to an ion is, the more the phase transfer equilibrium of the ions will be affected. If the complexation constant $\left(\mathrm{K}_{\mathrm{f}}\right)$ of an ionophore with one or more of the ions is strong enough, a meaningful difference between the observed selectivity and that expected according to the Hofmeister regime will be seen [26]. Based on the same hypothesis, the more strongly the ionophore complexes with a certain target ion, the larger the difference will be in the magnitude of the selectivity coefficients versus the series. The ISE based on the calcium-selective ionophore ETH 1001, with a $\mathrm{K}_{\mathrm{f}}$ value of $3.5 \times 10^{-2} \mathrm{M}$ for $\mathrm{Ca}^{2+}$ ions in the NPOE/PVC membranes, for example, has selectivity coefficients in the order of $10^{-6}$ for $\mathrm{Ca}^{2+}$ over $\mathrm{K}^{+}$and $\mathrm{Na}^{+}$, which is a vivid distinction from the series [27].

It is clear that there are other requirements beyond the formation of a strong complex with a specific ion to make an ionophore suitable for the construction of an ISE. In short the complexation of the ionophore must also be kinetically fast $[28,29]$. This quality, which lowers the free energy barrier for the free and complexed states and leads to a facile complexation, the ion-carrier must be preorganized and flexible to some extent [4].

Another factor limiting the applicability of an ionophore is its lipophilicity, which makes the ionophore compatible with the polymer membrane, which substantially diminishes the leaching of the ionophore from the organic membrane into the aqueous phase increasing the sensors life time and the reproducibility of its response. This is usually achieved by substituting long alkyl chains or other bulky organic groups to its binding framework.

The response of the ISE also depends on the type of interactions between the ionophore and the target ion, which can be of chemical or physical natures. The chemical interactions can be summarized 
as Lewis acid-base reactions of hard and/or soft types, hydrogen-binding, best-fit mechanisms, complexation, chelate effects, sandwich complex formation and precipitation reactions [30].

\subsection{The principle of the complexation reactions}

Complex formation is very important, especially in the science of biology. In this process, bonding interactions occur, which are usually weaker than the covalent bonding. The complex formation processes are characterized by the thermodynamic stability and selectivity, which depend on the energy amount ( $\mathrm{K}, \Delta \mathrm{G}$, etc.), and the kinetic stability and selectivity, which depend on the reaction rate.

The interaction between two species can be either attractive or repulsive. The former one results in complex formation. Stability, formation mechanism and formation or dissociation rates are the main parameters in complexation. The complex stoichiometry is another effective factor used to describe a complex. The complexes are divided into the two groups of addition (denoted by [S, L]) and inclusion complexes (denoted by [SCL]).

Complexation can actually be defined as a simple interaction between a donor (ligand) and an acceptor (substrate). In the case of inclusion complexes, however, there has to be a 2 or 3D cavity in the ligand structure in order to host the substrate [SCL] [31-34].

Once a ligand encounters several substrates $\left(\mathrm{S}_{1}, \mathrm{~S}_{2}, \mathrm{~S}_{3} \ldots\right)$, complex formation may happen according to the three routes of distinctive, selective or specific complexation.

In a distinctive complexation, the ligand (L) tends to form complexes with any of the substrates, which means the thermodynamic and kinetic effects between $\mathrm{L}$ and all substrates are identical and hence all $\mathrm{K}_{\mathrm{f}}$ values are equal. This is in accordance with selective complexation; the ligand prefers one of the substrates to the others and has a higher tendency to form a complex with it. In the specific complexation, on the other hand, L forms a complex with only one of the substrates.

Molecular recognition is based on selective or specific complexation routes, which lead to static, dynamic (kinetic) or a mixture of both selectivities.

This selective behavior can be very important, as in the case of drug consumption in the body, where the drug selectivity and its selective interaction are vital. The static selectivity considers the formation constant, the association energy, dissociation energy and the free energy $\left(\Delta G, K_{f}\right)$ since they help define the stability of complexes. Dynamic selectivity, on the other hand, considers the formation rate, the rate constant, the transition state, the activation energy as well as the rate of the forward and reverse reactions.

The characteristics of the ligand as well as the substrates are crucial in molecular recognition, because the selective bonding between the ligand and the substrate originates from this information. This information is literally stored in the ligand and is read out by the substrate. This characteristic information helps define the stability, selectivity, reactivity and transport of the complexes.

As stated before, the information stored in the ligand must be readout by the substrate and the association and dissociation rates control the readout.

Ion-molecule complexes are usually stronger than the molecule-molecule complexes, because of the strong interaction between ions and the molecule; however, there are some exceptions to this and some 
molecule-molecule complexes are strong. These exceptions are the result of hydrogen and hydrophilic bonding or strong acceptor-donor interaction.

\subsection{Factors effective in complexation}

Many inorganic cations are monomolecular and spherical in shape. As a result, it is the structure of the ionophores and their geometric factors that play important roles in determining the ionselectivities. There are basic factors, which can effectively change the selectivity of the ligand or the ionophore including: the ligand topology which can be sub-classified into the ligand dimentionality, its connectivities, shape, size, conformation, chirality and also its cavity or ring size. The degree of flexibility of the ligand holding of the donor atoms by the host backbone, which makes their positions suitable to match the shape of the coordination sphere of the target species, is another factor. Finally, the presence of lariats (functional groups, arms or chains added to the ionophores to change selectivity) has a great effect on binding.

Another very important factor that affects the complexation properties of the ligand binding sites which depends on the nature and number of the binding sites, is their shape, size, arrangement and reactivity.

The planarity of the ligand is also important in its complexation properties. Some factors, related to the cation and influencing the selectivity behavior, include the geometric shape of the ion, its charge density and its size (the ionic radius). The last factor seems to have a large influence on the selectivity. For instance, 12 -crown- 4 is selective toward the $\mathrm{Li}^{+}$ion, the radius of which is $0.68 \AA$, while another crown ether, 18-crown-6, interacts selectively with $\mathrm{K}^{+}$which has a radius of $1.33 \AA$.

In this case, the thickness of the ligand acts as a shield for the substrate lipophilicity. The polarity of the ligand is also influential. It is, as a result, important to distinguish and recognize the polar and nonpolar sides of the ligand. It seems to be necessary to state that another source of the effective information is the medium, which plays a central role in the complexation reaction.

One of these other sources is the nature of the solvent. It is clear that the substrate, the ligand and the complex are solvated. The ability of solvent molecules in solvating the ions, which lets the solvent compete with the ligand in coordinating the ion, has a fundamental role. Due to the necessity of cation and macrocycle dissolution before formation of the complex, the solvation processes of these species are expected to have a huge influence on the stability of the resulting complex in solution.

Another effective parameter includes the effect of the counter ion, which is of value in the case of the charged complexes. The neutralization of the charged complex is necessary to the transportation of the charged complex, which is normally done by the counter ion. The nature of the counter ion has a major effect on ion pair formation. For instance, a good ion pairing is not observed in the case of $\mathrm{Cl}^{-}$, while $\mathrm{MnO}_{4}{ }^{-}$creates strong ion pairs.

\section{Anion-Binding Ionophores}

For many reasons the number of anion selective electrodes, which constitute an important group of ISEs, is lower than that of the cationic sensors. One reason is that the size of anions is relatively larger than that of cations. Another reason is the various shapes and high hydration energy of anions. Finally, 
anions can have different forms based on the $\mathrm{pH}$ of the medium. However, the number of sensors for anions has been considerable [35].

Usually an ion-selective membrane, which can be either an inorganic salt or an organic polymeric matrix containing a metal complex as the ionophore, plays the role of the selector element of the potentiometric indicator electrode. In the case of the latter, a strong interaction between the ionophore and the anion is required, thus a complex shows a selective tendency which can be used in the construction of anion selective sensors. The potentiometric response, in the case of anion ISEs, is considered to be the result of the axial coordination of the target ion to the metal center [37-39].

Conventional ionophores (like quaternary ammonium salts) have been used in the construction of anion selective sensors with the selectivity order of $\mathrm{ClO}_{4}{ }^{-}>\mathrm{SCN}^{-}>$salicylate $>\mathrm{NO}_{3}{ }^{-}>\mathrm{Br}^{-}>\mathrm{NO}_{2}{ }^{-}=\mathrm{Cl}^{-}>$ $\mathrm{HCO}_{3}{ }^{-}>\mathrm{H}_{2} \mathrm{PO}_{4}{ }^{-}=\mathrm{F}^{-}=\mathrm{SO}_{4}{ }^{2-}$, which can be regarded to be merely based on the lipophilicity of the ions (i.e. Hofmeister selectivity). As in the case of cation ISEs, anion carriers with different selectivity sequences have been sought.

It was found that the use of metal complexes as the ionophore results in potentiometric anion selectivity patterns that are very different from the Hofmeister sequence which is believed to stem from the selective axial ligation of the anion with the metal ion centers in the complexes. These socalled anti-Hofmeister sequences can vary depending on the nature of the central metal [40], as is observed in the case of Schiff's base complexeof different metal ions. To explain such an effect we will review these interactions.

\subsection{Metal center-anion interaction}

The application of metal centers as anion binding receptors with anti-Hofmeister behavior has been very common. The metal centers can be either ionic (complexed in an organic ligand) or they can have organometallic natures. The latter, e. g. metalloporphyrins, methallophthalocyanines and Schiff bases have been more promising. The mentioned metal-ligand interactions induce an anion-selectivity in the membrane that significantly differs from those observed in the case of conventional anion ionophores containing lipophilic quaternary ammonium or phosphonium salts, which lead to lipophilicity based selectivity patterns. Such electrodes largely depend on the nature of the metal center of ionophore and the stability of the complex [41].

They application of both charged and neutral metal centers, depending on the organic ligand and the metal center, has been reported, which necessitates slight changes to the membrane composition.

As in the case of the cationic counterparts, it is necessary to add some lipophilic anionic sites to the membrane, so that the sensor selectivity is optimized. This is absolutely vital in the case of the neutral receptors.

\subsection{Anionic sensors with hydrogen bonding}

Hydrogen bonding, although weaker than the common electrostatic interactions resulting from axial coordination, can also play a crucial role in the recognition process. This mechanism is only possible through the proper orientation of the interacting functional groups which justifies the absence of hydrogen bonding during recognition in many cases. 


\subsection{Anionic sensors with quaternary ammonium or guanidinium sites}

As mentioned before, the Hofmeister pattern is observed in the case of the sensors with polymeric ion exchange membranes, containing cationic sites with no special tendencies. According to this selectivity pattern, the more hydrophilic anions (like $\mathrm{H}_{2} \mathrm{PO}_{4}{ }^{-}$and $\mathrm{Cl}^{-}$) are less favorable than the more lipophilic ones (like $\mathrm{ClO}_{4}{ }^{-}$and $\mathrm{NO}_{3}{ }^{-}$).

\section{4. Anionic sensors with trifluoroacetophenone receptors}

In contrast to the receptors described in the previous sections, the selectivities of which resulted from non-covalent interactions with the anion, the trifluoroacetophenone derivatives form a covalent bond with the target anion.

\section{Study of Complexation}

In practice, the selectivity behavior of an ionophore is evaluated after its incorporation into the sensor. For example membrane-based techniques have been used to evaluate the binding properties of the ionophore according to which the ISE response is studied with the membrane containing two ionophores. Also, in other methods, the ionophore-based membranes are sandwiched with an ionophore-free membrane then the responses at different interfaces are compared. Other methods have been developed to examine the selectivity and the potential of a would-be ionophore outside the membrane phase. For instance, the strength of the ion-ionophore interactions is studied in solution phases via NMR [4].

\subsection{Complexation study by conductometric method}

Conductivity measurements can be useful tools to investigate complexation. The measurements can be conducted with a Metrohm 660 conductivity meter and a dip-type conductivity cell, made of platinum black with a cell constant of $0.83 \mathrm{~cm}^{-1}$. In all measurements, the cell should be thermostated at the temperature of $25.0{ }^{\circ} \mathrm{C}$, using a Phywe immersion thermostat. In typical experiments, $25 \mathrm{~mL}$ of an ion solution $\left(1.0 \times 10^{-4} \mathrm{M}\right)$ are placed in a water-jacketed cell, equipped with a magnetic stirrer and connected to the thermostat, circulating water at the desired temperature. In order to keep the electrolyte concentration constant during the titration, it should be noted that both the starting solution and the titrant have the same ion concentration. Then, a known amount of an ionophore or a ligand $\left(1.0 \times 10^{-2} \mathrm{M}\right)$ solution is added in a stepwise manner, using a calibrated micropipette. The conductance of the solution is measured after each addition. The ligand addition is continued until the desired ionophore-to-ion mole ratio is achieved.

The 1:1 binding of the cations with the ionophore can be expressed by the following equilibrium:

$$
\mathrm{M}^{n+}+\mathrm{L} \stackrel{\mathrm{Kf}}{\longleftrightarrow} \mathrm{ML}^{n+}
$$

The corresponding equilibrium constant, $K_{\mathrm{f}}$, is given by 


$$
K_{f}=\frac{\left[\mathrm{ML}^{n+}\right]}{\left[\mathrm{M}^{n+}\right][\mathrm{L}]} \times \frac{f_{\left(\mathrm{ML}^{n+}\right)}}{f_{\left(\mathrm{M}^{n+}\right)} f_{(\mathrm{L})}}
$$

Here, $\left[\mathrm{ML}^{\mathrm{n}+}\right],\left[\mathrm{M}^{n+}\right],[\mathrm{L}]$ and $f$ represent the equilibrium molar concentration of the complexes, the free cation, the free ionophore and the activity coefficient of the indicated species, respectively. Under the diluted conditions, the activity coefficient of the unchanged ligand $f_{(L)}$ can be reasonably assumed to be unity [42]. The use of the Debye-Hückel limiting law of the 1:1 electrolytes [43] leads to the conclusion that $f_{\left(M^{n+}\right)} \approx f_{\left(M L^{n+}\right)}$, so the activity coefficient in Eq. (5) is canceled out. Therefore, the complex formation constant in terms of the molar conductance can be expressed as [44]:

$$
K_{f}=\frac{\left[M L^{n+}\right]}{\left[M^{n+}\right][L]}=\frac{\left(\Lambda_{M}-\Lambda_{o b s}\right)}{\left(\Lambda_{o b s}-\Lambda_{M L}\right)[L]}
$$

where

$$
K_{f}=C_{L}-\frac{C_{M}\left(\Lambda_{M}-\Lambda_{o b s}\right)}{\left(\Lambda_{o b s}-\Lambda_{M L}\right)}
$$

Here, $\Lambda_{\mathrm{M}}$ is the molar conductance of the cation before the addition of the ionophore; $\Lambda_{\mathrm{ML}}$ is the molar conductance of the complexes, $\Lambda_{\text {obs }}$ the molar conductance of the solution during titration, $C_{\mathrm{L}}$ the analytical concentration of the added ionophore and $C_{\mathrm{M}}$ the analytical concentration of the cation salt. The complex formation constant, $K_{\mathrm{f}}$ and the molar conductance of the complex, $\Lambda_{\mathrm{ML}}$, were obtained by computer fitting the Eqs. (5) and (6) to the molar conductance-mole ratio data, using the nonlinear least-squares program KINFIT [45-53].

\subsection{Complexation study by spectroscopic methods}

\subsubsection{UV-VIS study}

The ligand coordination with the ion can be investigated by spectroscopy, for example. From the UV/Vis spectra, as illustrated in Figure 1, it is possible to distinguish the interactions between the ligand and the ion. The substantial decrease in the absorbance at a certain wavelength of the ligand solution, after adding the ion solution stepwise, may give a new adsorption peak at another wavelength, which is related to complex formation. At the same time, the effects of the other ions on the spectrum of the carrier should be investigated. The detectable changes in the UV/Vis spectra should be considered [54-56]. 
Figure 1. An example of an UV-Vis. spectrum for complexation study. A: ligand spectrum; B: the complex spectrum; C: metal ion spectrum.

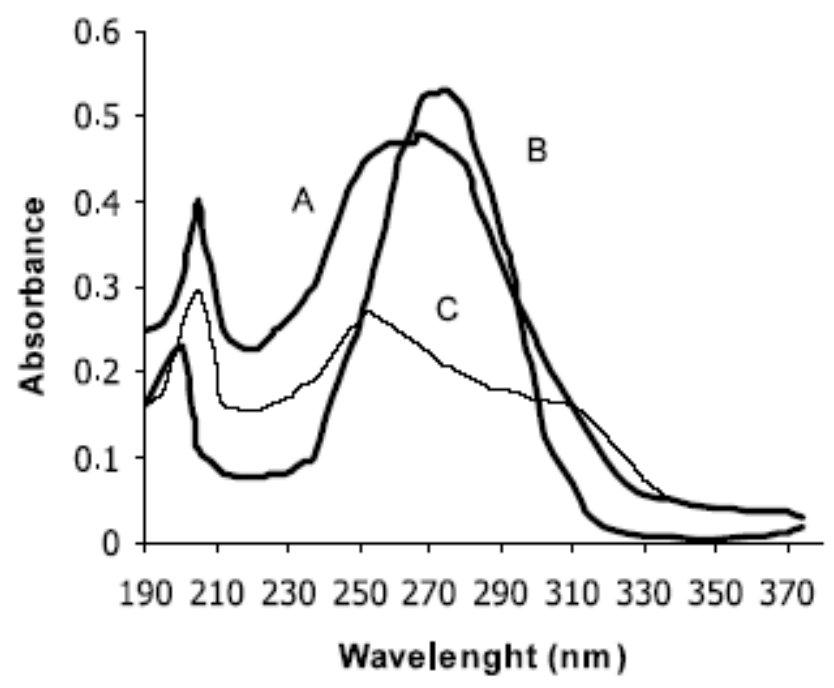

When a metal ion, $\mathrm{M}$, reacts with a ligand, $\mathrm{L}$, to form a 1:1 complex, the formation constant is given as:

$$
K_{f}=\frac{[M L]}{[M][L]}
$$

The mass balance equations and the observed absorbance given by:

$$
\begin{aligned}
& C_{M}=[M]+[M L] \\
& C_{L}=[L]+[M L] \\
& \Lambda_{o b s}=\varepsilon_{L}[L]+\varepsilon_{M L}[M L]=\Lambda_{o} / C_{L}[L]+\varepsilon_{M L}[M L]
\end{aligned}
$$

where $\mathrm{C}$ and e values are the analytical concentration and molar absorptivities of the species indicated and $\mathrm{A}$ is the absorbance of the ligand in the absence of metal ion. The mass balance equations can be solved in order to obtain an equation for the free ligand concentration, [L], as:

$$
K_{f}[L]^{2}+\left(1+K_{f}\left(C_{M}-C_{L}\right)\right)[L]-C_{L}=0
$$

For the evaluation of the formation constant from absorbance-mole ratio data, the non-linear leastsquares curve fitting program KINFIT was used.

\subsubsection{Fluorescence study}

The ligand complexation with the ion can be studied by the fluorescence method. The existence of sharp isobestic points in the resulting fluorescence spectra further support the formation of the complex between the ionophore and the ion [57]. 
Figure 2. An example of fluorescence spectrum for complexation study. The ligand fluorescence intensity is quenched in the presence of increseing concentration of metal ion.

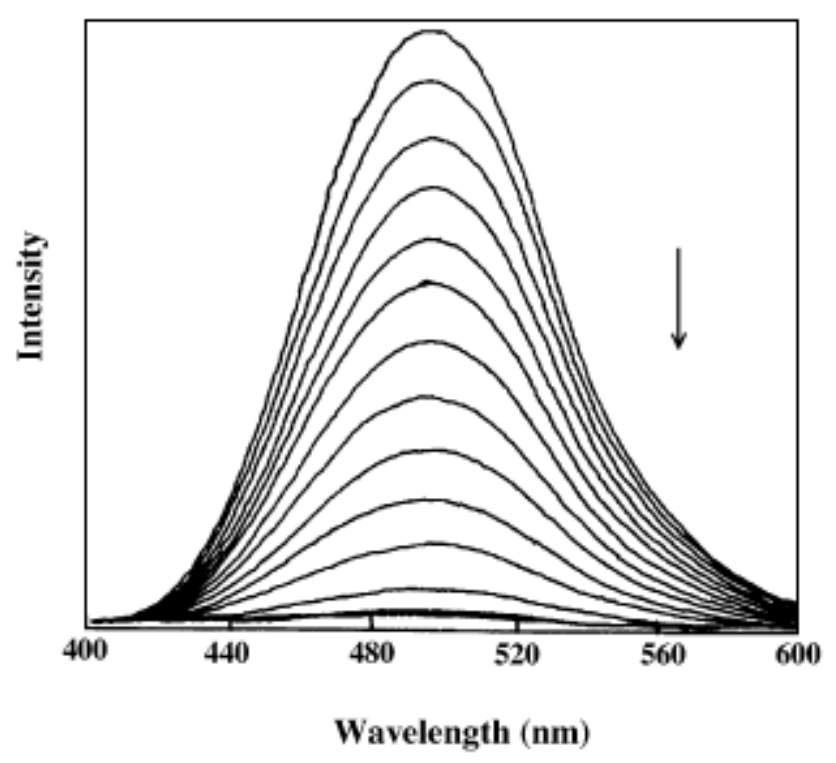

The ion concentrations were changed sequentially at a constant ligand concentration and the enhancement in the emission intensities is compared to that of the corresponding ligand.

The 1:1 complexation constant can be calculated from the emission intensity and the concentration of the metal ion, [M], as follows [58,59]:

$$
\frac{I-I_{0}}{I_{\infty}-I}=K\left\{[M]_{t}-[L]_{t}\left(\frac{I-I_{0}}{I_{\infty}-I_{0}}\right)\right\}
$$

where I is the emission response of the ligand at a certain ion concentration, $\mathrm{I}_{0}$ is the emission response of the ligand in the absence of the ion, $\mathrm{I}_{\infty}$ is the emission response when no further change occurred while continue adding ion, $[\mathrm{L}]_{\mathrm{t}}$ is the total concentration of the ligand molecule and $[\mathrm{M}]_{\mathrm{t}}$ represents the total ion concentration. The complexation constants were calculated using a non-linear curve-fitting method [60].

\subsubsection{NMR study}

Multinuclear NMR is a very powerful (although not ideal) technique to study alkali metal complexes with macrocyclic ligands, particularly in non-aqueous solutions. For instance, the use of ${ }^{23} \mathrm{Na}$ NMR for the study of the sodium ion complexes with five crown ethers, namely 15-crown-5 (15C5), benzo-15-crown-5 (B15C5), 18-crown-6 (18C6), dicyclohexyl-18-crown-6 (DC18C6) and dibenzo-18-crown-6 (DB18C6), in binary acetonitrile (AN)-dimethylformamide (DMF) mixtures can be considered. The ${ }^{23} \mathrm{Na}$ chemical shifts were determined as a function of the $[\mathrm{crown}] /\left[\mathrm{Na}^{+}\right]$mole ratio at $25.0 \pm 0.5^{\circ} \mathrm{C}$ in various AN-DMF solvent mixtures for different crown ethers used [61].

The formation constants of the corresponding 1:1 complexes were calculated from the variation of the ${ }^{23} \mathrm{Na}$ chemical shift with the crown/ $\mathrm{Na}^{+}$mole ratio. 


$$
\begin{aligned}
& \delta_{\text {obs }}=\left\{\left[K_{f} C_{M}-K_{f} C_{L}-1\right)+\left(K_{f}{ }^{2} C_{L}{ }^{2}+K_{f}{ }^{2} C_{M}{ }^{2}-2 K_{f}{ }^{2} C_{L} C_{M}+2 K_{f} C_{L}+2 K_{f} C_{M}+1\right)^{1 / 2} \times\right. \\
& \left.\left.\left(\delta_{M}-\delta_{M L}\right) / 2 K_{f} C_{M}\right]\right\}+\delta_{M L}
\end{aligned}
$$

where $K_{f}$ is the concentration formation constant for the $1: 1$ complex, $C_{L}$ and $C_{M}$ are the analytical concentrations of the crown ether and $\mathrm{Na}^{+}$ion, respectively, and $\delta_{\mathrm{M}}$ and $\delta_{\mathrm{ML}}$ are the corresponding chemical shifts of the free and complexed sodium ion. The non-linear least-squares curve fitting program KINFIT [45] was used to evaluate the $K_{f}$ and $\delta_{M L}$ values for the $1: 1$ complexes. The formation constants of all the 1:1 complexes were evaluated by computer fitting of the chemical shiftmole ratio data from equation 14.

\subsection{Complexation study by electrochemical methods}

\subsubsection{Polarographic study}

Among a variety of physicochemical methods used for the study of cation-macrocycle interactions, polarographic methods have shown their ability as very useful means of studying the electrochemical behaviour of macrocyclic compounds and the stability and selectivity of their complexes with various cations in both aqueous and non-aqueous media.

In the polarographic investigation of metal ion complexes, the difference between the half-wave potentials of the free and complexed metal ions is a measure of the complex stability [62]. The determination of the formation constants of the metal ion-macrocycle complexes, studied in different solvent mixtures, is based on measurements of the shifts in $E_{1 / 2}$ or $E_{p}$ brought about by the addition of an increasing amount of the ligands.

Figure 3. An example of polarographic study for complexation. Differential pulse polarogram of a metal ion in the absence (1) and in the presensce of the increasing ligand concentration (from 2 to 5).

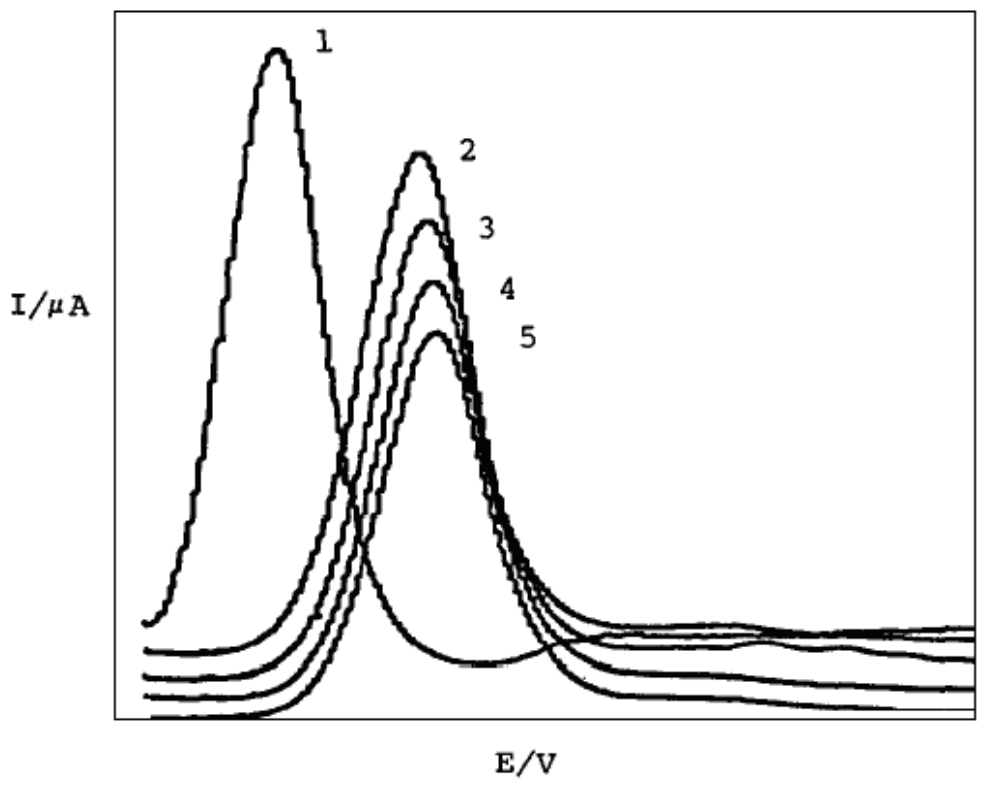


Depending on the reversibility of the systems studied and the relative stability of the resulting complexes, one of the following three different polarographic methods is used for the determination of the stability constants [63]:

Method 1. In the case of the reversible amalgam-forming reduction of labile complexes of relatively high stability, the shift in half-wave (or peak) potential to more negative values upon addition of an excess amount of ligand was found to be in accordance with the Lingane equation:

$$
\Delta E_{1 / 2}=\left(E_{1 / 2}\right) M-\left(E_{1 / 2}\right)_{C}=(R T / n F)\left(\ln K_{f}+\rho \ln [L]_{t}\right)
$$

where $\left(E_{1 / 2}\right)_{M}$ and $\left(E_{1 / 2}\right)_{C}$ are the half-wave potentials of the free and complexed metal ion, $n$ is the number of electrons transferred, $K_{f}$ is the complex formation constant, $[L]_{t}$ is the analytical concentration of the ligand and $p$ is the stoichiometry of the complex. The values of $p$ and $\log \mathrm{K}_{\mathrm{f}}$ can be obtained from the slopes and intercepts of the linear plots of $\Delta \mathrm{E}_{1 / 2} /(\mathrm{RT} / \mathrm{nF}) v s$. $\log [\mathrm{L}]_{\mathrm{t}}$, respectively.

Method 2. Measurement of the half-wave potential of the anodic polarographic signals resulting from the oxidation of mercury to its bivalent state in the presence of the ligands. The complex formation constants can be obtained from the following equation [64]:

$$
\Delta E_{1 / 2}=\left(E^{o} \text { Cell }=(R T / 2 F)\left(\ln K_{f}+\ln [L]_{t}^{\rho-1}\right)\right.
$$

where $\mathrm{E}_{\text {cell }}^{\circ}$ is the formal potential of the $\mathrm{Hg} / \mathrm{Hg}(\mathrm{II})$ half-cell $v s$. SCE.

Method 3. Measurement of the positive shift in the reversible cathodic half-wave potential of $\mathrm{Hg}^{2+}$ complexes (as indicator) with increasing concentration of another $\mathrm{M}^{2+}$ cation which can compete with $\mathrm{Hg}^{2+}$ for the ligand. The formation constants for $\mathrm{M}^{2+}$ complexes were obtained from the equation [65]:

$$
\Delta E_{1 / 2}=\left(E_{1 / 2}\right)_{H g M L}-\left(E_{1 / 2}\right)_{H g L}=(R T / 2 F)\left(\ln K_{f}+\rho \ln \left[M^{2+}\right]_{t}\right)
$$

where $\left(\mathrm{E}_{1 / 2}\right)_{\mathrm{HgML}}$ and $\left(\mathrm{E}_{1 / 2}\right)_{\mathrm{HgL}}$ are the cathodic half-wave potentials of the $\mathrm{Hg}^{2+} \mathrm{L} / \mathrm{Hg}$ system in the presence and absence of $\mathrm{M}^{2+}$ ion, respectively, and $\left[\mathrm{M}^{2+}\right]$ is the analytical concentration of the $\mathrm{M}^{2+}$ ion.

\subsubsection{Potentiometric study}

The stability constant of the $\mathrm{M}^{\mathrm{n}+}$-Ligand complex (equation 18 ) at various temperatures, $\mathrm{K}_{\mathrm{f}}$, can be determined by a competitive potentiometric method using a $\mathrm{Ag}^{+} / \mathrm{Ag}$ electrode as a probe. Simple potentiometric titration of the $\mathrm{Ag}^{+}$ions with a solution of the ligand can be used in case of $\mathrm{Ag}^{+}$. For example, calculation of $\mathrm{K}_{\mathrm{f}} \mathrm{Ag}^{+}$with dibenzopyridino-18-crown-6 (DBPY18C6) is shown as follows [66]:

$$
\left[\mathrm{Ag}^{+}\right]_{\mathrm{tot}}=\left[\mathrm{Ag}^{+}\right]+\left[\mathrm{Ag}^{+}-\mathrm{DBPY18C6}\right]
$$

For a solution containing $\mathrm{Ag}^{+}$and DBPY18C6, the total concentrations can be written as:

$$
M^{n+}+D B P Y 18 C 6 \stackrel{K m}{\longrightarrow} M^{n+}-D B P Y 18 C 6
$$




$$
M^{n+}+A g^{+}-D B P Y 18 C 6 \stackrel{K m}{\longrightarrow} M^{n+}-D B P Y 18 C 6+A g^{+}
$$

The stability constants of the $\mathrm{M}^{\mathrm{n}+}$ ion complexes, $\mathrm{K}_{\mathrm{M}}$, with DBPY18C6 (equation 20) at various temperatures can be determined by the double decomposition reaction of $\mathrm{M}^{\mathrm{n}+}$ with the corresponding $\mathrm{Ag}^{+}$complex (Equation 19) by monitoring the equilibrium concentration of the silver ions in the presence of the $\mathrm{M}^{\mathrm{n}+}$ ions using the equilibrium constant $\mathrm{K}_{\mathrm{E}}=\mathrm{K}_{\mathrm{M}} / \mathrm{K}_{\mathrm{Ag}}$ for reaction 20 together with the stability constant $\mathrm{K}_{\mathrm{Ag}}$ obtained from the direct titration of the $\mathrm{Ag}^{+}$ions with the ligand.

$$
\left[M^{n^{+}}\right]_{t o t}=\left[M^{n^{+}}\right]+\left[M^{n^{+}}-D B P Y 18 C 6\right]
$$

In this case, the total concentrations of $\mathrm{M}^{\mathrm{n}+}$ and DBPY18C6 are written as:

$$
[D B P Y 18 C 6]_{t o t}=[D B P Y 18 C 6]+\left[\mathrm{Ag}^{+}-D B P Y 18 C 6\right]+\left[M^{n^{+}}-D B P Y 18 C 6\right]
$$

A MINIQUAD program was used to compute the formation constants $K_{A g}$ and $K_{M}$ from the resulting potentialconcentration data [67].

\subsection{Complexation study by theoretical calculation}

In order to obtain a clue about the tendency of the ionophore to the ions, some ab-initio quantummechanical calculations can be carried out. The pairwise interaction energy, $\Delta E(\mathrm{~A}-\mathrm{B})$, between two molecules ( $\mathrm{A}$ and $\mathrm{B}$ ) is estimated as the difference between the energy of the $E(A-B)$ complex and the energies of the isolated partners:

$$
\Delta E(\mathrm{~A}-\mathrm{B})=E(\mathrm{~A}-\mathrm{B})-E(\mathrm{~A})-E(\mathrm{~B})
$$

The calculations were performed with the second-order Møller-Plesset (MP2) perturbation theory $[68,69]$, which includes the electron correlation energy in addition to the Hartree-Fock (HF) energy. The use of such a calculation level is fully justified by the fact that the description of the base stacking requires calculations with the explicit inclusion of the electron correlation [70]. The interaction energy at a given order of the Møller-Plesset (MP) perturbation expansion is calculated as:

$$
\Delta E_{M P n}=\Delta E_{H F}+\sum_{i=2}^{n} \Delta E_{C o r r}(M P i)
$$

where $\Delta E_{\mathrm{HF}}$ is the HF energy and $\Delta E_{\mathrm{Corr}}(\mathrm{MP} i)$ is the $i^{\text {th }}$ order perturbative correction to the correlation energy. Only the valence electrons were explicitly correlated in our computations, which correspond to the usual frozen core approximation. The perturbation expansion (24) to the second order, which is expected to take into account the major contributions of the van der Waals energies (electrostatic, polarization, dispersion, electron transfer and exchange contributions) also is limited [71].

For most of the atoms, the lanl2mb basis set is used (due to the difference in atom properties) for the optimization of the molecules. All the calculations were performed using the Gaussian 98 package [72]. The interaction energies for the ionophore and some metal ions can be calculated from the equation (23). 
Figure 4. Some examples of theoretical calculation for complexation study. Optimal conformation of the ionophore complexation with ions is shown in these figures.
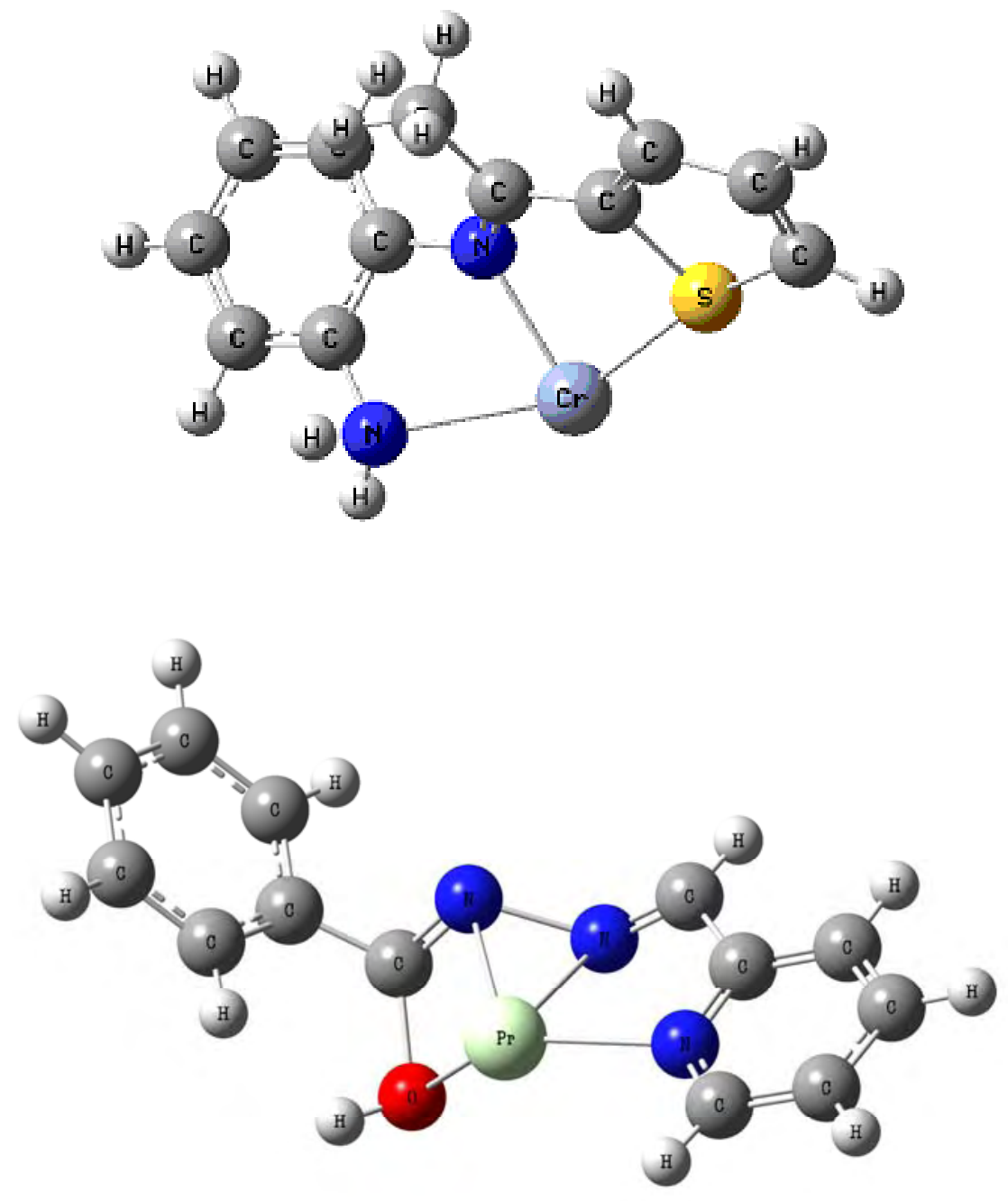

\section{Schiff's Bases as Supramolecular Sensing Materials in the Construction of Potentiometric} Membrane Sensors

A very good example of supramolecular studies is the design and synthesis of molecules or metal complexes that can be used for the construction of sensing membranes that selectively respond to a particular analyte, because of the incorporation of the designed species. In such a case, it is necessary to match the size and binding properties of the species to make it or its derivative as selective towards the desired analyte as possible.

Supramolecular ionophores can be cation or anion selective. These sensing materials can be classified as ring-shaped or cyclic ionophores, cylindrical ionophores, hemispherical ionophores (also called molecular baskets or cages) and acyclic or linear compounds.

Cyclic ionophores are often cyclic antibiotics or peptides, such as the $\mathrm{K}^{+}$-selective ionophore valinomycin or crown ethers like 14-crown-4 or 12-crown-4 derivatives, which demonstrate tendencies toward $\mathrm{Li}^{+}$. 
Cylindrical ionophores include as most important representative calixarenes, which have a cyclic scaffold that includes a derivative of phenol such as a sodium selective calix[4]arene. Hemispherical ionophores are structurally similar to crown compounds with the difference of having a bridge. They look like bowls with different cavity sizes.

On the contrary to having shown good ion selectivities in some cases, linear compounds are not as important as macrocycles. The most important member of this family are podands, which have more sites gathered around a rigid core by a flexible linkage and that resemble the arms of the molecule. Due to the selectivity of this group, chelate effects can be observed, which increases the selectivity compared to rigid ionophores. Although the structure of these compounds cannot be geometrically

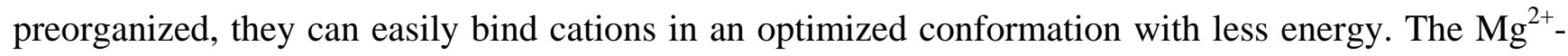
selective bi-podand is an example of this group [4].

Figure 5. Structure of a podand.

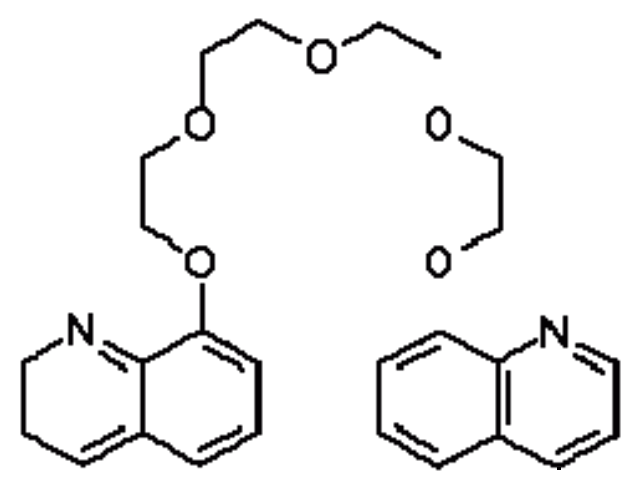

Supramolecular ionophores can be classified as podands (Figure 5), with a crown-ether like structure which only has a linear part that can form a wrap around metal ions complexes. Another group is the Schiff's bases and crown ethers which will be described later. Tripod ligand molecules (Figure 6) constitute another group of such compounds. The tripods can be either symmetrical or nonsymmetrical [73,74].

Figure 6. A symmetric tripod ligand.

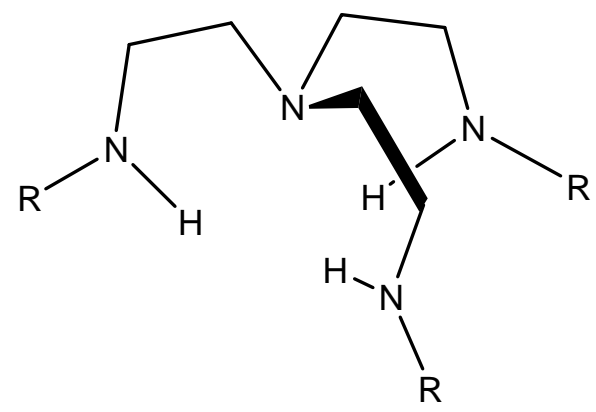


Planar macrocycles like porphyrin (Figure 7) or tetralactam are well-known supramolecular ionophores. Catananes and rotaxanes constitute another group of the supramolecular ionophres, in addition to cyclodextrines that are water soluble compounds.

Figure 7. Structure of a porphyrin.

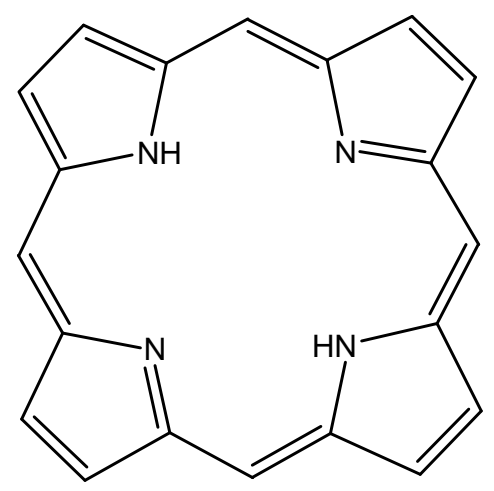

Calixarenes (Fig. 8) and their different derivatives are also supramolecular ionophores [74], the structures of which allow them to interact with cations, anions, neutral species and their various combinations.

Figure 8. Structure of a calix[4]arene.

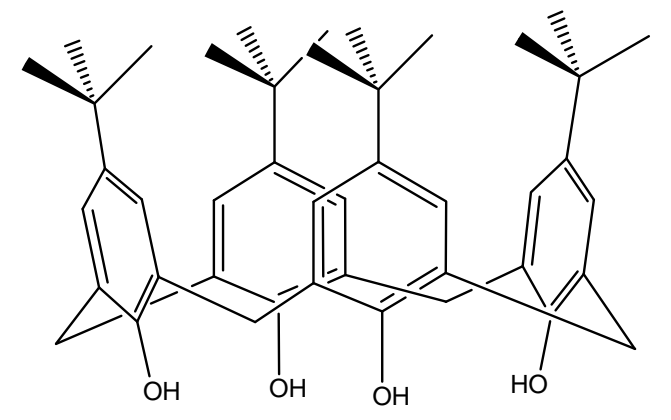

We will try to focus on the Schiff's base and crown ethers as supramolecular sensing material due to their widespread applications.

\subsection{Structure of Schiff's bases}

Schiff's bases (also called azomethines or imines) are named after Hugo Schiff. These compounds are functional groups with the general formula $\mathrm{R}_{1} \mathrm{R}_{2} \mathrm{C}=\mathrm{N}-\mathrm{R}_{3}$. They contain carbon-nitrogen double bonds in which nitrogen atoms are connected to an aryl or alkyl group. The role of the $\mathrm{R}_{3}$ group is to stabilize the iminic Schiff's base

These compounds are synthesized from an aromatic amine and a carbonyl compound (e.g. aldehydes, ketones, Scheme 1) through a nucleophilic addition, which leads to the formation of a 
hemi-aminal, and the consequent dehydration to generate an imine. The reaction of 4,4'diaminodiphenyl ether with $o$-vanillin can be regarded a typical reaction [75].

Application of aldehydes will lead to the formation of imines of $\mathrm{R}_{1} \mathrm{HC}=\mathrm{N}-\mathrm{R}_{2}$ type. This is while the result of the same reaction with ketones are $R_{1} R_{2} C=N-R_{3}$ type amines (it should be noted that the reaction of ketones occurs more slowly than that of aldehydes. The overall mechanism of forming Schiff's bases is according to the multi-step reaction below:

Scheme 1. Schiff's base formation from aldehyde or ketone.

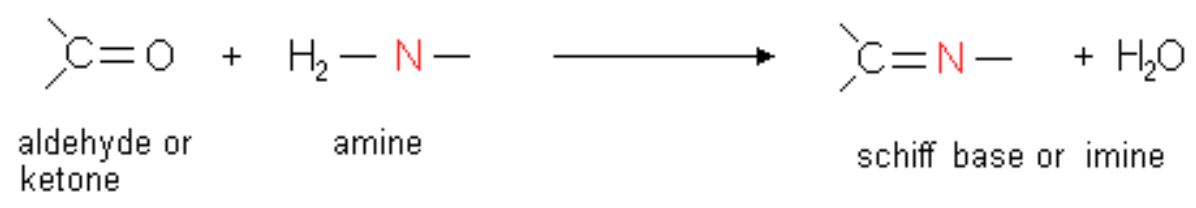

An imine (Schiff base), such as that formed from o-vanillin, forms complexes with metal ions via $\mathrm{N}$ and $\mathrm{O}$ donor atoms. The steric and electronic effects around the metal core can be finely tuned through the appropriate selection of electron withdrawing or electron donating substituents in the Schiff's bases. These $\mathrm{N}$ and $\mathrm{O}$ atoms induce two opposite electronic effects: the phenolate oxygen is regarded a hard donor, which stabilizes the higher oxidation states while the imine nitrogen is a softer donor and will hence stabilize the lower oxidation states of the metal ion [76].

\subsection{Application of Schiff's bases and their complexes}

Schiff's bases are considered "privileged ligands" which are active and well-designed. These ligands have been extensively studied in coordination chemistry, and are found to be stable under a variety of oxidative and reductive conditions [77]. Schiff's bases are actually able to stabilize many different metals in various oxidation states, controlling the performance of metals in a large variety of useful catalytic transformations [78,79].

Transition metal complexes of these compounds have been used in the catalysis of diverse processes, such as oxygen and atom transfer, enantioselective epoxidation and aziridination, mediating organic redox reactions and as mediators in other oxidation processes. However, very little is known about their complex formation equilibria in the solution [80] and also about the use of salens and their complexes as carriers in the ion-selective electrodes [81].

Schiff's bases have the potentials to be used in different areas such as electrochemistry, bioinorganic, catalysis, metallic deactivators, separation processes and environmental chemistry [79] and they are becoming increasingly important in the pharmaceutical, dye and plastic industries as well as in the field of liquid-crystal technology [76].

\subsection{Different types of Schiff's bases:}

There are about 135 articles on the potentiometric membranes based on Schiff's bases and their metal complexes as sensing materials. This family can be divided to the two groups of symmetric and 
asymmetric Schiff's base. Salens and salophen can be symmetric or asymmetric but hydrazones are the members of the asymmetric Schiff's bases.

\subsubsection{Schiff's bases and their complexes}

Many potentiometric sensors use symmetric Schiff's bases as the ion recognition element. Symmetric Schiff's bases can act as tetra or hexa dentate ligands and can form a strong and week complex with metal ions. As mentioned earlier the nature and number of the $\mathrm{N}, \mathrm{O}, \mathrm{S}$ donor atoms and the semicavity size of the ligand are important in the formation of the stable selective complexes. Schiff's base complexes have also proved to be good ion carriers for the anion selective sensors. Table 1 gives a summary of a number of reported membrane sensors based on symmetric and asymmetric Schiff's bases and their complexes.

Table 1. A number of reported potentiometric membrane sensors based on Schiff's bases and their complexes.

\begin{tabular}{|c|c|c|c|c|c|}
\hline Cation & Ionophore & $\begin{array}{c}\text { Slope } \\
\left(\mathrm{mV} \mathrm{decade}^{-1}\right)\end{array}$ & $\begin{array}{l}\text { Linear Range } \\
\text { (M) }\end{array}$ & $\begin{array}{c}\text { Most Important } \\
\text { Interfering ions } \\
\left(\log K_{\text {sel }}>-2\right)\end{array}$ & Ref. \\
\hline $\mathrm{Al}^{+3}-1$ & $\begin{array}{l}\text { bis(5-phenyl azo salicylaldehyde)- } \\
\text { 2,3-naphthalene diimine } \\
\text { (5PHAZOSALNPHN) }\end{array}$ & 19.3 & $5.0 \times 10^{-6}-1.0 \times 10^{-2}$ & $\mathrm{Li}^{+}, \mathrm{NH}_{4}{ }^{+}, \mathrm{Ag}^{+}$ & 82 \\
\hline $\mathrm{Sn}^{2+}-1$ & $\begin{array}{l}\text { 6-(4-nitrophenyl)-2,4-diphenyl- } \\
\text { 3,5-diazabicyclo-[3.1.0]-hex-2-ene } \\
\text { (NDDBH) }\end{array}$ & $28.8 \pm 1.1$ & $1.0 \times 10^{-5}-1.0 \times 10^{-1}$ & $\begin{array}{l}\mathrm{Tl}^{+}, \quad \mathrm{Mn}^{2+}, \\
\mathrm{Ba}^{2+}, \mathrm{Cs}^{+}\end{array}$ & 83 \\
\hline $\mathrm{Pb}^{2+}-1$ & $\begin{array}{l}\text { bis(acetylacetone)-p-phenylene- } \\
\text { diamine-lead(II) }\left[\mathrm{LPb}\left(\mathrm{NO}_{3}\right)_{2}\right] \mathrm{H}_{2} \mathrm{O} \\
\text { complex ionophore }\end{array}$ & $30.0 \pm 0.2$ & $1 \times 10^{-5}-1 \times 10^{-1}$ & - & 84 \\
\hline $\mathrm{Pb}^{2+}-2$ & $\begin{array}{l}N, N \text {-bis(5-methylsalicylidene)-p- } \\
\text { diphenylenemethane diamine }\end{array}$ & 29.4 & $5.0 \times 10^{-6}-0.10$ & $\begin{array}{l}\mathrm{Zn}^{2+}, \quad \mathrm{Fe}^{3+}, \quad \mathrm{K}^{+}, \\
\mathrm{NH}_{4}^{+}\end{array}$ & 85 \\
\hline $\mathrm{Pb}^{2+}-3$ & $\begin{array}{l}N, N \text {-bis(3-methylsalicylidine)-p- } \\
\text { phenylmethane diamine }\end{array}$ & $30.3 \pm 0.6$ & $2.0 \times 10^{-5}-0.10$ & $\mathrm{Na}^{+}, \mathrm{K}^{+}, \mathrm{NH}_{4}^{+}$ & 86 \\
\hline $\mathrm{Pb}^{2+}-4$ & Schiff base as a neutral carrier & $29.4 \pm 0.5$ & $1.0 \times 10^{-5}-1.0 \times 10^{-1}$ & $\mathrm{Na}^{+}, \mathrm{K}^{+}, \mathrm{Cu}^{2+}$ & 87 \\
\hline $\mathrm{Pb}^{2+}-5$ & $\begin{array}{l}N, N^{\prime} \text {-bis-thiophene-2-yl- } \\
\text { methyleneethane-1,2-diamine }\end{array}$ & 29.79 & $1.0 \times 10^{-5}-1.0 \times 10^{-1}$ & - & 88 \\
\hline $\mathrm{Pb}^{2+}-6$ & $\begin{array}{l}N, N^{\prime} \text {-bis(salicylidene)-2,6- } \\
\text { pyridinediamine }\end{array}$ & 29.4 & $1.0 \times 10^{-6}-1.0 \times 10^{-1}$ & $\mathrm{~K}^{+}, \mathrm{Ag}^{+}$ & 89 \\
\hline $\mathrm{Pb}^{2+}-7$ & $\begin{array}{l}N, N \text { '-dibenzyl-1,4,10,13-tetraoxa- } \\
7,16 \text {-diazacyclooctadecane (I) }\end{array}$ & $30.0 \pm 0.1$ & $8.2 \times 10^{-6}-1.0 \times 10^{-1}$ & $\mathrm{Cd}^{2+}, \mathrm{Zn}^{2+}, \mathrm{Ag}^{+}$ & 90 \\
\hline $\mathrm{Y}^{3+}-1$ & $\begin{array}{l}\text { A new Schiff's base with sulfur } \\
\text { and nitrogen donor atoms (2- } \\
(\{(E) 1,2-\text { diphenyl-2-[(2-2- } \\
\text { sulfanylphenyl)imino]ethylidene }\} \\
\text { amino)-1-benzenethiol }\end{array}$ & 19.2 & $1.0 \times 10^{-7}-1.0 \times 10^{-2}$ & $\mathrm{Sc}^{3+}$ & 91 \\
\hline
\end{tabular}


Table 1. Cont.

\begin{tabular}{|c|c|c|c|c|c|}
\hline $\mathrm{La}^{3+}-1$ & $\begin{array}{l}\text { bis (2-mercaptoanil) diacetyl } \\
\text { (BMDA) }\end{array}$ & 19.7 & $\begin{array}{l}10^{-5}-10^{-1} \text { and } 10^{-6}- \\
10^{-1}\end{array}$ & $\mathrm{Ce}^{3+}, \mathrm{Gd}^{3+}$ & 92 \\
\hline $\mathrm{La}^{3+}-2$ & $\begin{array}{l}\text { bis(thiophenal)phenylen-1,3- } \\
\text { diamine (TPD) }\end{array}$ & 19.6 & $1.0 \times 10^{-7}-1.0 \times 10^{-1}$ & $\mathrm{Sm}^{3+}, \mathrm{Ce}^{3+}$ & 93 \\
\hline $\mathrm{Ce}^{3+}-1$ & $\begin{array}{l}N, N \text {-bis[2-(salicylidene- } \\
\text { amino)ethyl]ethane-1,2-diamine }\end{array}$ & 20 & $1.41 \times 10^{-7}-1.0 \times 10^{-2}$ & $\mathrm{La}^{3+}$ & 94 \\
\hline $\mathrm{Gd}^{3+}-1$ & $\begin{array}{l}S-N \text { Schiff s base (2-[\{3-[(2- } \\
\text { sulfanylphenyl)imino)- 1- } \\
\text { methylbutylidene }\} \text { amino]phenyl } \\
\text { hydrosulfide (SMPH) }\end{array}$ & $19.8 \pm 0.3$ & $1.0 \times 10^{-1}-1.0 \times 10^{-5}$ & $\mathrm{~Tb}^{3+}, \mathrm{Dy}^{3+}, \mathrm{Eu}^{3+}$ & 95 \\
\hline $\mathrm{Gd}^{+3}-2$ & $\begin{array}{l}\text { bis(thiophenal) pyridine-2,6- } \\
\text { diamine (BPD) }\end{array}$ & $19.4 \pm 0.4$ & $1.0 \times 10^{-6}-1.0 \times 10^{-1}$ & $\mathrm{La}^{3+}, \mathrm{Mg}^{2+}, \mathrm{Hg}^{2+}$ & 96 \\
\hline $\mathrm{Tb}^{+3}-1$ & $\begin{array}{l}N, N \text {-bis(pyrrolidene) benzene-1,2- } \\
\text { diamine }\end{array}$ & 19.8 & $1.0 \times 10^{-5}-1.0 \times 10^{-1}$ & $\mathrm{La}^{3+}, \mathrm{Yb}^{3+}, \mathrm{Dy}^{3+}$ & 97 \\
\hline $\mathrm{Dy}^{+3}-1$ & $\begin{array}{l}N, N \text {-bis(pyrrolidene) benzene-1,2- } \\
\text { diamine }\end{array}$ & $20.6 \pm 0.2$ & $1.0 \times 10^{-5}-1.0 \times 10^{-1}$ & $\mathrm{Ce}^{3+}, \mathrm{La}^{3+}$ & 98 \\
\hline $\mathrm{Dy}^{+3}-2$ & $\begin{array}{l}\text { a new asymmetrical Schiff's base } \\
{[(E)-N \text {-(2-hydroxybenzylidene)- }} \\
\text { benzohydraide }] \text { or BBH }\end{array}$ & $20.1 \pm 0.8$ & $1.0 \times 10^{-2}-1.0 \times 10^{-6}$ & $\mathrm{Yb}^{3+}, \mathrm{Tm}^{3+}, \mathrm{Na}^{+}$ & 99 \\
\hline $\mathrm{Ho}^{+3}-1$ & $\begin{array}{l}N \text {-(1-thien-2-yl-methylene)-1,3- } \\
\text { benzothiazol-2-amine }\end{array}$ & 19.7 & $10^{-5}-10^{-2}$ & $\mathrm{Lu}^{3+}, \mathrm{Dy}^{3+}, \mathrm{Gd}^{3+}$ & 100 \\
\hline $\mathrm{Lu}^{+3}-1$ & $\begin{array}{l}\text { a new asymmetrically } S \text { - } N \text { Schiff's } \\
\text { base, } N \text {-(thien-2-ylmethylene)- } \\
\text { pyridine-2,6-diamine (TPD) }\end{array}$ & $20.5 \pm 0.4$ & $1.0 \times 10^{-2}-1.0 \times 10^{-6}$ & $\mathrm{Nd}^{3+}, \mathrm{Dy}^{3+}, \mathrm{Gd}^{3+}$ & 101 \\
\hline $\mathrm{UO}_{2}{ }^{2+}-1$ & $\begin{array}{l}\text { 2,2'-[1,2-ethanediyl bis (nitrilo- } \\
\text { ethylidene)]bis(1-naphthalene) }\end{array}$ & $28.5 \pm 0.8$ & $10^{-1}-10^{-7}$ & $\mathrm{Mg}^{2+}, \mathrm{Cu}^{2+}$ & 102 \\
\hline $\mathrm{Cr}^{3+}-1$ & $\begin{array}{l}\text { a new tridentate } S, N, O \text { Schiff's } \\
\text { base 4-hydroxysalicylade-2- } \\
\text { mercaptoanil (TSNO) }\end{array}$ & 20.2 & $3.0 \times 10^{-6}-1.0 \times 10^{-1}$ & $\mathrm{Na}^{+}, \mathrm{La}^{3+}, \mathrm{Pb}^{2+}$ & 103 \\
\hline $\mathrm{Cr}^{3+}-2$ & $\begin{array}{l}\text { 2,3,8,9-tetraphenyl-1,4,7,10- } \\
\text { tetraazacyclododeca-1,3,7,9- } \\
\text { tetraene (TTCT) }\end{array}$ & 19.5 & $1.0 \times 10^{-6}-1.0 \times 10^{-1}$ & $\mathrm{Ag}^{+}$ & 104 \\
\hline $\mathrm{Cr}^{3+}-3$ & $\begin{array}{l}\text { 2-hydroxybenzaldehyde-O,O'-(1,2- } \\
\text { dioxetane-1,2-diyl) oxime }\end{array}$ & 19.6 and 19.2 & $\begin{array}{l}1.5 \times 10^{-6}-8.0 \times 10^{-3} \\
M \text { for PME and } \\
4.0 \times 10^{-7}-3.0 \times 10^{-3} \\
M \text { for CGCE }\end{array}$ & $\mathrm{Ce}^{3+}, \mathrm{Cu}^{2+}$ & 105 \\
\hline $\mathrm{Cr}^{3+}-4$ & $\begin{array}{l}N \text {-(1-thien-2-ylethylidene)- } \\
\text { benzene-1,2-diamine (SNS) }\end{array}$ & $19.9 \pm 0.3$ & $1.0 \times 10^{-6}-1.0 \times 10^{-1}$ & $\mathrm{Fe}^{3+}, \mathrm{Eu}^{3+}, \mathrm{Mg}^{2+}$ & 106 \\
\hline $\mathrm{Cr}^{3+}-5$ & $\begin{array}{l}\text { Schiff bases, } N \text {-(acetoacetanilide)- } \\
\text { 1,2-diaminoethane (L-1) and } N, N^{\prime}- \\
\text { bis (acetoacetanilide)-triethylene- } \\
\text { tetrammine (L-2) }\end{array}$ & 19.8 & $8.9 \times 10^{-8}-1.0 \times 10^{-1}$ & - & 107 \\
\hline $\mathrm{Mn}^{2+}-1$ & $\begin{array}{l}N, N^{\prime}, N^{\prime \prime}, N^{\prime \prime \prime}-1,5,8,12 \text {-tetraaza- } \\
\text { dodecane-bis(salicylaldiminato) } \\
\left(\mathrm{H}_{2} \mathrm{~L}\right)\end{array}$ & 30 & $5.0 \times 10^{-6}-1.0 \times 10^{-1}$ & $\mathrm{Cd}^{2+}, \mathrm{Fe}^{3+}, \mathrm{Ni}^{2+}$ & 108 \\
\hline
\end{tabular}


Table 1. Cont.

\begin{tabular}{|c|c|c|c|c|c|}
\hline $\mathrm{Fe}^{3+}-1$ & $\begin{array}{l}\text { 2-[(2-hydroxy-1-propenyl-buta- } \\
\text { 1,3-dienylimino)-methyl]-4-p- } \\
\text { tolylazo-phen ol [HPDTP] }\end{array}$ & $28.5 \pm 0.5$ & $3.5 \times 10^{-6}-4.0 \times 10^{-2}$ & $\mathrm{Fe}^{2+}, \mathrm{Cr}^{3+}$ & 109 \\
\hline $\mathrm{Co}^{2+}-1$ & $\begin{array}{l}\text { 5-((4-nitrophenyl)azo)- } N \text {-(2',4'- } \\
\text { dimethoxyphenyl)salicylaldimine }\end{array}$ & 29 & $9.0 \times 10^{-7}-1.0 \times 10^{-2}$ & $\mathrm{~K}^{+}, \mathrm{Ag}^{+}$ & 110 \\
\hline $\mathrm{Ni}^{2+}-1$ & thiophene-derivative Schiff base & $29.5 \pm 1.0$ & $5.0 \times 10^{-6}-1.0 \times 10^{-1}$ & - & 111 \\
\hline $\mathrm{Ni}^{2+}-2$ & $\begin{array}{l}N, N^{\prime} \text {-bis-(4-dimethylamino- } \\
\text { benzylidene)-benzene-1,2-diamine }\end{array}$ & 30 & $1.0 \times 10^{-2}-2.0 \times 10^{-7}$ & $\mathrm{Tl}^{+}, \mathrm{Ag}^{+}$ & 112 \\
\hline $\mathrm{Ni}^{2+}-3$ & $\begin{array}{l}\text { Schiff bases, } N \text {-(2-hydroxy- } \\
\text { benzyl)- } N \text { '-(2-hydroxy- } \\
\text { benzylidene)-ethylenediamine and } \\
N \text {-(2-hydroxybenzylidene)-Al'-(2- } \\
\text { picolyl)ethylenediatmine (II) }\end{array}$ & 30 and 29 & $\begin{array}{l}6.3 \times 10^{-6} \text { to } 5.0 \times \\
10^{-1} \\
\text { and } 3.2 \times 10^{-6} \text { to } 5.0 \\
\times 10^{-1}\end{array}$ & $\mathrm{Ag}^{+}, \mathrm{Co}^{2+}, \mathrm{Hg}^{2+}$ & 113 \\
\hline $\mathrm{Ni}^{2+}-4$ & $\begin{array}{l}N^{1}, N^{2} \text {-bis((naphthalen-1- } \\
\text { ymethylene)ethane-1,2-diamine }\end{array}$ & 29.9 & $1.0 \times 10^{-1}-5.0 \times 10^{-6}$ & $\begin{array}{l}\mathrm{Na}^{+}, \quad \mathrm{K}^{+}, \quad \mathrm{Ba}^{2+}, \\
\mathrm{Co}^{2+}, \mathrm{Ag}^{+}, \mathrm{Zn}^{2+}\end{array}$ & 114 \\
\hline $\begin{array}{c}\mathrm{Cu}^{2}, \mathrm{Ni}^{2+}- \\
1\end{array}$ & $\begin{array}{l}\text { two Schiff base ligands: } \\
N \text {-[2-thienylmethylidene]-2- } \\
\text { propanolamine (TNAIIP) and N-[- } \\
\text { 2-thienylmethylidene]amino- } \\
\text { propane (TNAP) }\end{array}$ & 29 & $1.0 \times 10^{-6}-1.0 \times 10^{-2}$ & $\mathrm{Cd}^{2+}, \mathrm{Fe}^{3+}$ & 115 \\
\hline $\begin{array}{c}\mathrm{Cu}^{2}, \mathrm{Ni}^{2+}- \\
2\end{array}$ & $\begin{array}{l}\text { Electrodes } 1 \text { and } 2 \text { are based on } \\
\text { mixed complexes of } \mathrm{Cu}(\mathrm{II}) \text { and } \\
\mathrm{Ni(II)} \text { with } N \text {-[2-thienyl- } \\
\text { methylidene]-2-aminopyridine as } \\
\text { ligand and electrodes } 3 \text { and } 4 \text { are } \\
\text { based on the mixed complexes } \\
\text { with } N, N^{\prime} \text {-[2,2'-bis-thienyl- } \\
\text { methylidene]tolylene }\end{array}$ & 29 & $1.0 \times 10^{-5}-1.0 \times 10^{-2}$ & $\mathrm{Co}^{2+}, \mathrm{Fe}^{3+}$ & 116 \\
\hline $\begin{array}{c}\mathrm{Cu}^{2}, \mathrm{Ni}^{2+}- \\
3\end{array}$ & $\begin{array}{l}N \text {-[2-thienylmethilidene]-2- } \\
\text { aminoethanol (TNAHE) }\end{array}$ & 29 and 29 & $\begin{array}{l}10^{-6}-10^{-1} \text { and } 10^{-5}- \\
10^{-1}\end{array}$ & - & 117 \\
\hline $\mathrm{Cu}^{2+}-1$ & naphthol-derivative Schiff's base & $29 \pm 1$ & $5.0 \times 10^{-6}-5.0 \times 10^{-2}$ & $\mathrm{Na}^{+}, \mathrm{Hg}^{2+}, \mathrm{Ni}^{2+}$ & 118 \\
\hline $\mathrm{Cu}^{2+}-2$ & $\begin{array}{l}\text { bis-2-thiophenal propanediamine } \\
\text { (TPDA) }\end{array}$ & 29.1 & $1.0 \times 10^{-1}-6.0 \times 10^{-8}$ & $\mathrm{Ag}^{+}$ & 119 \\
\hline $\mathrm{Cu}^{2+}-3$ & $\begin{array}{l}\text { new thiophene-derivative Schiffs } \\
\text { base }\end{array}$ & $29.3 \pm 0.7$ & $6.0 \times 10^{-8}-1.0 \times 10^{-1}$ & $\mathrm{Zn}^{2+}, \mathrm{Hg}^{2+}$ & 120 \\
\hline $\mathrm{Cu}^{2+}-4$ & $\begin{array}{l}\text { diphenylisocyanate bis(acetyl- } \\
\text { acetone) ethylenedinnine (DIBAE) }\end{array}$ & 29.8 & $1.0 \times 10^{-1}-1.0 \times 10^{-6}$ & - & 121 \\
\hline $\mathrm{Cu}^{2+}-5$ & $\begin{array}{l}\text { 2,2'-[4,4'diphenyl-methanebis- } \\
\text { (nitrilomethylidyne)]-bisphenol }\end{array}$ & 29 & $8.0 \times 10^{-6}-1.0 \times 10^{-1}$ & $\mathrm{Hg}^{2+}$ & 122 \\
\hline $\mathrm{Cu}^{2+}-6$ & $\begin{array}{l}\text { 2,2-[1,2-ethandiyl-bis(nitrilo- } \\
\text { methylidine)-bis] m-cresol-(l),2,2- } \\
\text { [1,2-ethandiyl-bis(nitrilo- } \\
\text { methylidine)-bis] p-cresol(II) and } \\
\text { 2,2'-[1,2-ethandiyl-bis(nitrito- } \\
\text { methylidine)-bis]ortho cresole(III) }\end{array}$ & $\begin{array}{l}29.2 \pm \quad 0.3 \\
29.7 \pm 0.3 \text { and } \\
28.2 \pm 0.3\end{array}$ & $1.0 \times 10^{-5}-1.0 \times 10^{-1}$ & $\mathrm{Ni}^{2+}, \mathrm{Co}^{2+}, \mathrm{Pb}^{2+}$ & 123 \\
\hline
\end{tabular}


Table 1. Cont.

\begin{tabular}{|c|c|c|c|c|c|}
\hline $\mathrm{Cu}^{2+}-7$ & $\begin{array}{l}N, N \text { '-bis-pyridin-2-ylmethylene- } \\
\text { naphthalene-1,8-diamine }\end{array}$ & 29.6 & $10^{-6}-10^{-2}$ & $\mathrm{Cu}^{2+}$ & 124 \\
\hline $\mathrm{Cu}^{2+}-8$ & $\begin{array}{l}\text { Bis(2-hydroxyacetophenone)- } \\
\text { butane-2,3-dihydrazone (BHAB) }\end{array}$ & 29.6 & $5.0 \times 10^{-8}-1.0 \times 10^{-2}$ & - & 125 \\
\hline $\mathrm{Cu}^{2+}-9$ & $\begin{array}{l}\text { Copper (II) complex of 2,4- } \\
\text { dimethyl-1,5,9,12-tetraaza- } \\
\text { cyclopentadeca-1,4-diene }\end{array}$ & 29.9 & $1.1 \times 10^{-6}-1.0 \times 10^{-1}$ & $\mathrm{Co}^{2+}, \mathrm{Mn}^{2+}, \mathrm{Ni}^{2+}$ & 126 \\
\hline $\mathrm{Cu}^{2+}-10$ & $\begin{array}{l}\text { 2-(1'-(4'-(1"-hydroxy-2"- } \\
\text { naphthyl)-methyleneamino)butyI } \\
\text { imino-methyl)-1-naphthol (BHNB) } \\
\text { as a novel Schiff base }\end{array}$ & 29 & $10^{-6}-10^{-1}$ & $\mathrm{Tl}^{+}$ & 127 \\
\hline $\mathrm{Cu}^{2+}-11$ & $\begin{array}{l}\text { Schiff Base complexes, derived } \\
\text { from 2,3-diaminopyridine and } \\
\text { omicron-vanilin }\end{array}$ & 29.6 & $5.0 \times 10^{-6}$ to $1.0 \times 10^{-1}$ & $\mathrm{Hg}^{2+}, \mathrm{Ag}^{+}$ & 128 \\
\hline $\begin{array}{l}\mathrm{Cu}^{2+}-12 \\
\text { (micro) }\end{array}$ & $\begin{array}{l}\text { a symmetrical hexadentate Schiffs } \\
\text { base 2-\{1-(E)-2-((Z)-2-\{(E)-2-[(Z)- } \\
\text { 1-(2-hydroxyphenyl)ethylidene] } \\
\text { hydrazono)-1-methylpropylidene)- } \\
\text { hydrazono]ethyl)phenol (HDNOS) }\end{array}$ & $25.9 \pm 0.3$ & $1.0 \times 10^{-11}-1.0 \times 10^{-5}$ & $\mathrm{Ni}^{2+}, \mathrm{Pb}^{2+}, \mathrm{Cd}^{2+}$ & 129 \\
\hline $\mathrm{Cu}^{2+}-13$ & $\begin{array}{l}\text { copper(II) salicylaniline Schiffs } \\
\text { base }\end{array}$ & 30 & $10^{-6}-10^{-2}$ & $\mathrm{Li}^{+}, \mathrm{Na}^{+}, \mathrm{Cs}^{+}, \mathrm{k}^{+}$ & 130 \\
\hline $\mathrm{Cu}^{2+}-14$ & naphthol-derivative Schiff's base & 29.5 & $5.0 \times 10^{-6}-5.0 \times 10^{-2}$ & $\mathrm{Hg}^{2+}, \mathrm{Ni}^{2+}, \mathrm{Na}^{+}$ & 131 \\
\hline $\mathrm{Zn}^{2+}-1$ & $\begin{array}{l}N, N^{\prime} \text {-bis(acetylacetone)ethylene- } \\
\text { diimine }\end{array}$ & 30.0 & $1.0 \times 10^{-6}-1.0 \times 10^{-1}$ & $\mathrm{Cu}^{2+}, \mathrm{Al}^{3+}, \mathrm{Cd}^{2+}$ & 132 \\
\hline $\mathrm{Ag}^{+}-1$ & $\begin{array}{l}\text { Schiff base- } p \text {-tert-butyl- } \\
\text { calix[4]arene }\end{array}$ & 59.7 & $1.0 \times 10^{-5}-.0 \times 10^{-1}$ & $\mathrm{Hg}^{2+}$ & 133 \\
\hline $\mathrm{Ag}^{+}-2$ & $\begin{array}{l}\text { a dioxime-type Schiff base, } N, N^{\prime} \text { - } \\
\text { bis(2'-hydroxyimino-1'-phenyl- } \\
\text { propylidene)-1,3-propanediamine, } \\
\text { PHO3, derived from } \alpha \text {-isonitroso- } \\
\text { propiophenone and 1,3-diamino- } \\
\text { propane }\end{array}$ & 59 & $10^{-6.3}-10^{-1.1}$ & $\mathrm{Hg}^{2+}$ & 134 \\
\hline $\mathrm{Ag}^{+}-3$ & $\begin{array}{l}\text { Schiff base } p \text {-tert-butyl calix- } \\
\text { [4]arene derivatives containing } N \\
\text { and } O \text { as binding sites }\end{array}$ & 59 & $1.0 \times 10^{-5}-.0 \times 10^{-1}$ & $\mathrm{Hg}^{2+}$ & 135 \\
\hline $\mathrm{Ag}^{+}-4$ & $\begin{array}{l}\text { calix[4]arene compound of } \\
\text { 5,11,17,23-tetra-tert-butyl-25,27- } \\
\text { dihydroxy-calix[4]arene-thia- } \\
\text { crown-4 }\end{array}$ & $53.8 \pm 1.6$ & $1.0 \times 10^{-6}-1.0 \times 10^{-2}$ & $\mathrm{Hg}^{2+}$ & 136 \\
\hline $\mathrm{Ag}^{+}-5$ & calix[4] arene derivative & 58.9 & $1.0 \times 10^{-5}-1.0 \times 10^{-1}$ & $\mathrm{~K}^{+}, \mathrm{NH}_{4}^{+}, \mathrm{Na}^{+}$ & 137 \\
\hline $\mathrm{Ag}^{+}-6$ & $\begin{array}{l}\text { [bis 5-(4-nitrophenyl } \\
\text { azo)salisylaldimine] 1,8-diamino, } \\
\text { 3,6-dioxooctane (BNSAO) }\end{array}$ & 56.2 and 58.4 & $\begin{array}{l}1.9 \times 10^{-6}-2.7 \times \\
10^{-2} \text { and } 9.0 \times 10^{-7} \\
-3.1 \times 10^{-2}\end{array}$ & $\mathrm{~K}^{+}, \mathrm{NH}_{4}^{+}$ & 138 \\
\hline
\end{tabular}


Table 1. Cont.

\begin{tabular}{|c|c|c|c|c|c|}
\hline $\mathrm{Ag}^{+}-7$ & $\begin{array}{l}\text { 5,11,17,23-tetra-tert-butyl-25,27- } \\
\text { dihydroxy-calix[4]arene-thia- } \\
\text { crown-4 }\end{array}$ & $53.8 \pm 1.6$ & $1.0 \times 10^{-6}-1.0 \times 10^{-2}$ & $\mathrm{Hg}^{2+}$ & 139 \\
\hline $\mathrm{Ag}^{+}-8$ & $\begin{array}{l}\text { 7,8: 16,17-dibenzo- 6,9,15,18- } \\
\text { tetraoxo- 1,5,10,14-tetrathia- } \\
\text { cyclooctadeca-7,16- diene } \\
{[\mathrm{Bz}(2) \mathrm{Oxo}(4)(18) \text { dieneS(4) }}\end{array}$ & 58.4 & $1.26 \times 10^{-6}-1.0 \times 10^{-1}$ & $\mathrm{Tl}^{+}, \mathrm{Hg}^{2+}, \mathrm{Pb}^{2+}$ & 140 \\
\hline $\mathrm{Cd}^{2+}-1$ & $\begin{array}{l}\text { 5-[((4-Methyl phenyl) azo)- } N \text {-(6- } \\
\text { amino-2-pyridin) salicylaldimine] } \\
\text { (S-1), and 5-[((4-methyl phenyl) } \\
\text { azo)- } N \text {-(2-diamino-2-cyano-1- } \\
\text { ethyl cyanide) salicylaldehyde] (S- } \\
\text { 2) }\end{array}$ & 28 and 22 & $\begin{array}{l}1.5 \times 10^{-1}-7.5 \times 10^{-7} \\
\text { and } \\
2.0 \times 10^{-1}-4.0 \times 10^{-7}\end{array}$ & $\mathrm{~Pb}^{2+}, \mathrm{Ni}^{2+}$ & 141 \\
\hline $\mathrm{Cd}^{2+}-2$ & $\begin{array}{l}N, N^{\prime} \text {-[bis(pyridm-2-yl)- } \\
\text { formylidene] butane- 1,4-diamine } \\
\text { (SI) and N-(2-pyridinyl- } \\
\text { methylene)-1,2-benzenediamine } \\
\text { (S-2) }\end{array}$ & 29.5 & $7.9 \times 10^{-8}-1.0 \times 10^{-1}$ & $\mathrm{Cu}^{2+} \mathrm{NH}^{4+} \mathrm{Cr}^{3+}$ & 142 \\
\hline $\begin{array}{c}\mathrm{Hg}^{+2}, \mathrm{Cu}^{+2} \\
-1 \\
\end{array}$ & $\begin{array}{l}\text { Tetraethylthiuram disulfide was } \\
\text { chosen as a chemical modifier }\end{array}$ & 79.4 and 43.1 & $\begin{array}{l}10^{-7}-10^{-3} \text { and } \\
10^{-7.18}-10^{-3.67}\end{array}$ & $\mathrm{Mg}^{2+}, \mathrm{Al}^{3+}$ & 143 \\
\hline $\mathrm{Hg}^{2+}-1$ & $\begin{array}{l}\text { sulfur Schiff's base 1-(2-hydroxy- } \\
\text { 1,2-diphenylethylidene)thio- } \\
\text { semicarbazide (HDPET) }\end{array}$ & 29 & $1.0 \times 10^{-6}-2.0 \times 10^{-2}$ & $\mathrm{Ag}^{+}$ & 144 \\
\hline $\mathrm{Hg}^{2+}-2$ & $\begin{array}{l}\text { bis[5-((4-nitrophenyl)azo } \\
\text { salicylaldehyde)] (BNAS) }\end{array}$ & 30 & $5.0 \times 10^{-2}-7.0 \times 10^{-7}$ & - & 145 \\
\hline $\mathrm{Hg}^{2+}-3$ & $\begin{array}{l}\text { ethylenediamine bisthiophene- } \\
\text { carboxaldehyde (EDBT) }\end{array}$ & $30.0 \pm 0.4$ & $10^{-7}-10^{-2}$ & $\mathrm{Ag}^{+}$ & 146 \\
\hline $\mathrm{Hg}^{2+}-4$ & $\begin{array}{l}\text { Ethyl-2-(benzoylamino)-3-(2- } \\
\text { hydroxy-4-methoxyphenyl)-2- } \\
\text { propenoate (EBHMP) }\end{array}$ & $48.5 \pm 1.0$ & $3.0 \times 10^{-7}-3.1 \times 10^{-2}$ & $\mathrm{Cu}^{2+}, \mathrm{Cd}^{2+}, \mathrm{Pb}^{2+}$ & 147 \\
\hline $\mathrm{Hg}^{2+}-5$ & $\begin{array}{l}\text { bis(2-hydroxybenzophenone) } \\
\text { butane-2,3-dihydrazone (HBBD) }\end{array}$ & 29.7 & $1.0 \times 10^{-6}-1.0 \times 10^{-1}$ & $\mathrm{Fe}^{3+}, \mathrm{Cd}^{2+}, \mathrm{La}^{3+}$ & 148 \\
\hline $\mathrm{SCN}^{-}-1$ & $\begin{array}{l}\text { tricoordinate Schiff base copper(II) } \\
\text { complex }\end{array}$ & -57.6 & $2.6 \times 10^{-6}-1.0 \times 10^{-1}$ & - & 149 \\
\hline $\mathrm{SCN}^{-}-2$ & $\begin{array}{l}\text { two zinc(II) ions and two } \\
\text { molecules of the bis- } N, O \text {-bidentate } \\
\text { Schiff base } 2,2 \text { '-[methylenebis(4,1- } \\
\text { phenylenenitrilomethylidyne)]bis- } \\
\text { phenol }\end{array}$ & -57.5 & $10^{-3.5}-10^{-2}$ & $\mathrm{~N}^{3-}, \mathrm{NO}_{2}^{-}$ & 150 \\
\hline $\mathrm{SCN}^{-}-3$ & cadmium-Schiff's base complex & -57 & $1.0 \times 10^{-5}-1.0 \times 10^{-1}$ & - & 151 \\
\hline $\mathrm{SCN}^{-}-4$ & $\begin{array}{l}\text { ( } N, N^{\prime} \text {-bis-salicylidene-1,2- } \\
\text { ethylenediamine) }\end{array}$ & -59.1 & $10^{-6}-10^{-1}$ & $\mathrm{MnO}_{4}^{-}, \mathrm{I}^{-}$ & 152 \\
\hline $\mathrm{SCN}^{-}-5$ & $\begin{array}{l}\text { 2.2-[(1,3-dimethyl-1,3- } \\
\text { propanediylidene)dinitrilo]bis- } \\
\text { benzenethiolato cadmium(II) }\end{array}$ & -58.9 & $10^{-6}-10^{-1}$ & $\mathrm{MnO}_{4}^{-}, \mathrm{ClO}_{4}^{-}, \mathrm{Br}^{-}$ & 153 \\
\hline
\end{tabular}


Sensors 2008, 8

1669

\begin{tabular}{|c|c|c|c|c|c|}
\hline $\mathrm{SCN}^{-}-6$ & $\begin{array}{l}\text { butane-2,3-dione } \\
\text { bis(salicylhydrazonato) zinc(II) }\end{array}$ & -56.5 & $10^{-6}-10^{-1}$ & $\mathrm{ClO}_{4}^{-}$ & 154 \\
\hline $\mathrm{SO}_{4}{ }^{2-}-1$ & Schiff base complex of Zn(II) & $\begin{array}{ll}-29.7 & \text { and } \\
29.3 & \end{array}$ & $5.0 \times 10^{-5}-10^{-1}$ & $\mathrm{SCN}^{-}, \mathrm{ClO}_{4}^{-}$ & 155 \\
\hline $\mathrm{SO}_{4}{ }^{2-}-2$ & $\begin{array}{l}\text { strontium Schiff's base complex } \\
\text { (SS) }\end{array}$ & -29.2 & $10^{-2}-10^{-6}$ & $\mathrm{SO}_{3}{ }^{2-}, \mathrm{CO}_{3}{ }^{2-}, \mathrm{Cl}^{-}$ & 156 \\
\hline $\mathrm{SO}_{4}{ }^{2-}-3$ & zinc-Schiff base & -29.2 & $10^{-2}-10^{-6}$ & - & 157 \\
\hline $\mathrm{SO}_{4}{ }^{2-}-4$ & $\begin{array}{l}N, N \text { '-ethylenebis(5-hydroxy- } \\
\text { salicylideneiminato) } \\
\text { chromium(III) Chloride }\end{array}$ & -28.9 & $1.5 \times 10^{-6}-4.8 \times 10^{-2}$ & $\mathrm{I}^{-}, \mathrm{HPO}_{4}^{-}$ & 158 \\
\hline $\mathrm{F}^{-}-1$ & Gallium(III)-Schiff base & -61.1 & $1.0 \times 10^{-5}-1.0 \times 10^{-1}$ & $\mathrm{SCN}^{-}$ & 159 \\
\hline $\mathrm{Cl}^{-}-1$ & ruthenium(III) Schiff's base & -54.5 & $1.0 \times 10^{-1}-3.0 \times 10^{-6}$ & - & 160 \\
\hline $\mathrm{Cl}^{-}-2$ & Schiff base complex of cobalt(II) & -59 & $2.5 \times 10^{-5}-0.5 \times 10^{-1}$ & $\mathrm{Br}^{-}$ & 161 \\
\hline $\mathrm{I}^{-}-1$ & Schiff base complex of Fe(III) & -71.0 & $1.0 \times 10^{-6}-5.0 \times 10^{-1}$ & $\mathrm{SCN}^{-}, \mathrm{F}^{-}, \mathrm{NO}_{2}^{-}$ & 162 \\
\hline $\mathrm{I}^{-}-2$ & $\begin{array}{l}\text { [5,10,15,20-tetrakis(4- } N, N \text { - } \\
\text { dimethylaminobenzene)por- } \\
\text { phyrinato]Mn(III) acetate }\end{array}$ & -59.4 & $1.0 \times 10^{-2}-7.5 \times 10^{-6}$ & $\begin{array}{l}\text { Salicylate, SCN } \\
\mathrm{ClO}_{4}^{-}\end{array}$ & 163 \\
\hline $\mathrm{I}_{3}{ }^{-}-1$ & $\begin{array}{l}\text { bis (salicylaldehyde) ethylene- } \\
\text { diamine mercury(II) complex MS) }\end{array}$ & -59.0 & $5.0 \times 10^{-8}-10 \times 10^{-2}$ & - & 164 \\
\hline $\mathrm{I}_{3}{ }^{-}-2$ & $\begin{array}{l}N, N^{\prime} \text {-1,2-propylene-bis-(5-methyl } \\
\text { salicylidene iminato) copper }(\mathrm{H})\end{array}$ & -61.4 & $4.0 \times 10^{-5}-0.7 \times 10^{-1}$ & $\mathrm{I}^{-}, \mathrm{SCN}^{-}, \mathrm{ClO}_{4}^{-}$ & 165 \\
\hline $\mathrm{I}_{3}{ }^{-}-3$ & $\begin{array}{l}\text { a Charge-Transfer Complex } \\
\text { of (1,3-diphenyldihydro-1H- } \\
\text { Imidazole-4,5-dione dioxide } \\
\text { with Iodide }\end{array}$ & -59.3 & $10^{-7}-10^{-1}$ & - & 166 \\
\hline $\mathrm{I}_{3}{ }^{-}-4$ & $\begin{array}{l}\text { 2-((( 2((( E)-1-( 2-hydroxyphenyl) } \\
\text { methylidine)amino)phenyl) imino) } \\
\text { methyl)phenol with iodine ( CTC) }\end{array}$ & -59 & $5.0 \times 10^{-8}-1.0 \times 10^{-2}$ & - & 167 \\
\hline $\mathrm{I}_{3}{ }^{-}-5$ & $\begin{array}{l}\text { Schiff base 2,2'[4,4'-diphenyl- } \\
\text { methane bis (nitromethylidyne)] } \\
\text { bisphenol, L, with copper (II) and } \\
\text { schiff base 2,2'[4,4'-diphenyl- } \\
\text { methane bis (nitromethylidyne)] } \\
\text { bisphenol, L, with iron (III) }\end{array}$ & -60 & $\begin{array}{l}6.0 \times 10^{-6}-8.0 \times 10^{-1} \\
\text { and } \\
5.0 \times 10^{-5}-1.0 \times 10^{-1}\end{array}$ & SCN $^{-}$, Salicylate & 168 \\
\hline $\mathrm{I}_{3}^{-}-6$ & bis- $N, O$-bidentate Schiff base & -61.4 & $4.0 \times 10-5-0.7 \times 10-1$ & I- & 169 \\
\hline Salycilate & Schiff base complexes of Co(III) & -57.2 & $1.6 \times 10^{-6}-1.0 \times 10^{-1}$ & $\mathrm{SCN}^{-}$ & 170 \\
\hline Salycilate & $\begin{array}{l}\text { the complex } N, N^{\prime}-1,4 \text {-butylene } \\
\text { bis(3-methyl salicylidene iminato) } \\
\text { copper(II) }\end{array}$ & -59.1 & $1.0 \times 10^{-6}-1$ & - & 171 \\
\hline Cysteine & $\begin{array}{l}N, N^{\prime} \text {-bis(salicylidene)-1,2- } \\
\text { phenylenediaminocobalt(II) }\end{array}$ & -59 & $2.0 \times 10^{-6}-1.0 \times 10^{-2}$ & - & 172 \\
\hline
\end{tabular}

Structures of some of the above ionophores are depicted in Figures 9-15. 
Figure 9. Structure of bis(5-phenyl azo salicylaldehyde) 2,3-naphthalene diimine (5PHAZOSALNPHN) $\left(\mathrm{Al}^{3+}-1\right)$.

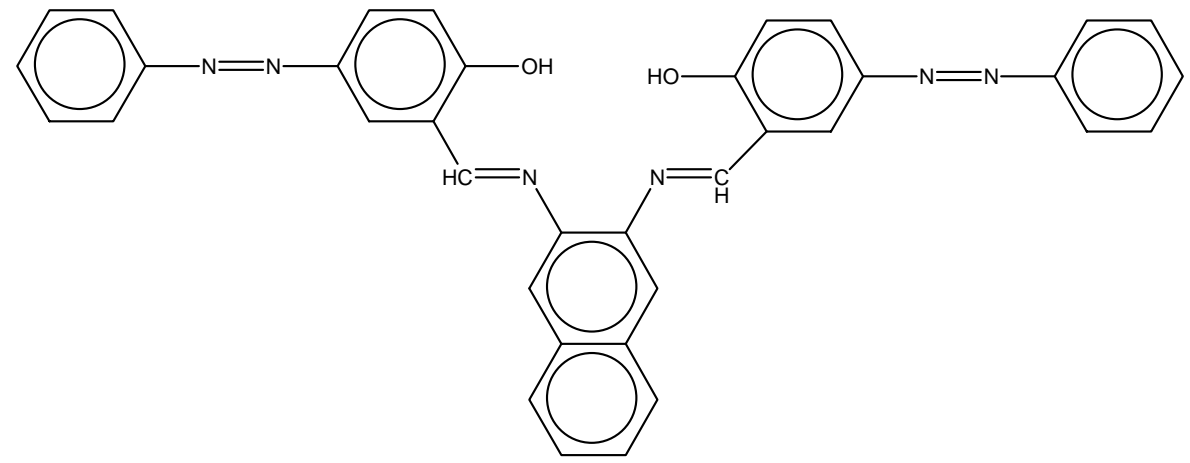

Figure 10. Structures of two suitable ionophores used in construction of the $\mathrm{Pb}^{2+}$ selective membrane sensors.

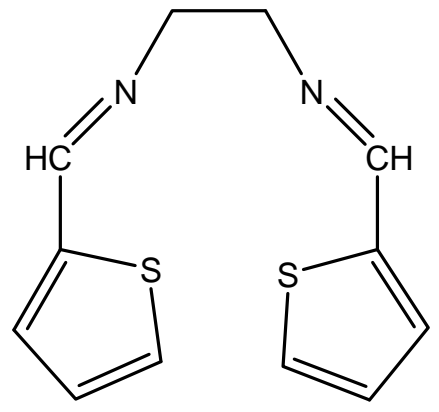

$\mathrm{Pb}^{2+}-5$<smiles>Oc1ccccc1/C=N\c1cccc(/N=C/c2ccccc2O)n1</smiles>

$\mathrm{Pb}^{2+}-6$

Figure 11. Structures of some ionophores used in construction of the lanthanide selective membrane sensors.<smiles>CC1=Nc2ccccc2SS1=Nc1ccccc1S</smiles>

$\mathrm{La}^{3+}-1$<smiles>C(=N/CCC/N=C/c1ccc[nH]1)\c1ccc[nH]1</smiles>

$\mathrm{Dy}^{+3}-1$<smiles>C(=N/c1cccc(/N=C/c2cccs2)n1)\c1cccs1</smiles>

$\mathrm{Gd}^{+3}-2$ 
Figure 12. Structures of two suitable ionophores used in construction of the $\mathrm{Cr}^{3+}$ selective membrane sensors.<smiles>Oc1ccc(/C=N\c2ccccc2S)c(O)c1</smiles>

$$
\mathrm{Cr}^{3+}-1
$$

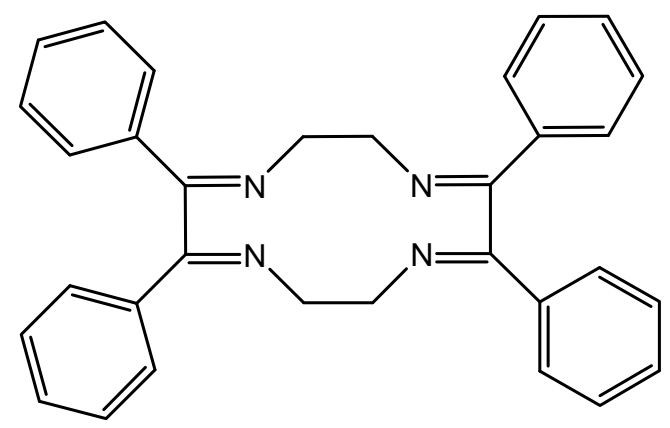

$\mathrm{Cr}^{3+}-2$

Figure 13. Structures of some symmetric Schiff's base ionophores used in construction of the $\mathrm{Cu}^{2+}$ selective membrane sensors.<smiles>CC(=O)C(NC(=O)c1ccccc1)C(C)=NCCN=C(C)C(NC(=O)c1ccccc1)C(C)=O</smiles>

$\mathrm{Cu}^{2+}-4$<smiles>CC(=N/N=C(C)\C(C)=N/N=C(/C)c1ccccc1O)c1ccccc1O</smiles>

$\mathrm{Cu}^{2+}-8$

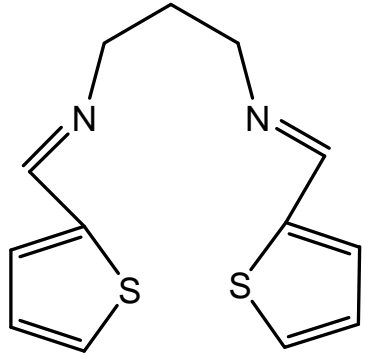

$\mathrm{Cu}^{2+}-2$

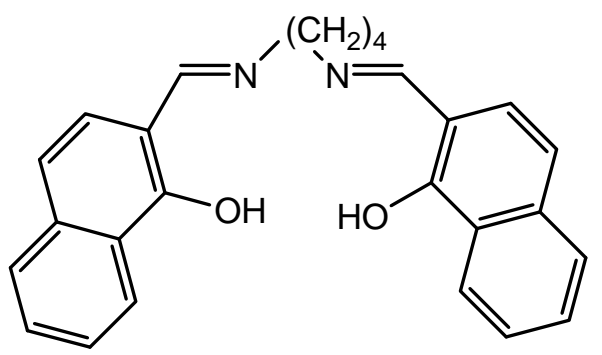

$\mathrm{Cu}^{2+}-10$

Figure 14. Structures of ionophores used in construction of the $\mathrm{Ag}^{+}, \mathrm{Cd}^{2+}$ and $\mathrm{Hg}^{2+}$ selective membrane sensors.<smiles>Cc1ccccc1C(=O)SCCCCSC(=O)c1ccccc1C(=O)SCCCCSC(=O)c1ccccc1</smiles>

$\mathrm{Ag}^{+}-8$<smiles>C(=N/CCCC/N=C/c1ccccn1)\c1ccccn1</smiles>

$\mathrm{Cd}^{2+}-2$

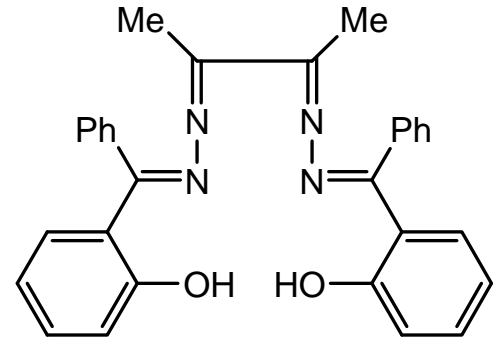

$\mathrm{Hg}^{2+}-5$ 
Figure 15. Structures of some suitable Schiff's base complexes used in construction of some anion selective membrane sensors.<smiles></smiles>

$\mathrm{SCN}^{-}-6$<smiles></smiles>

$\mathrm{SO}_{4}{ }^{2-}-4$

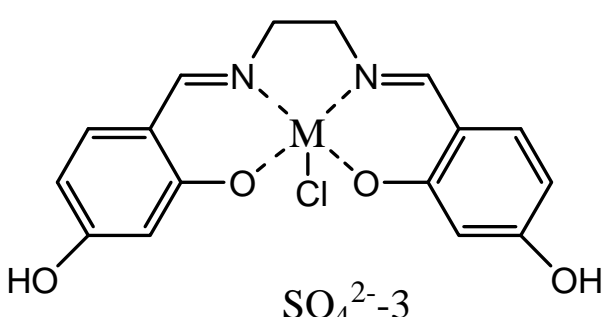

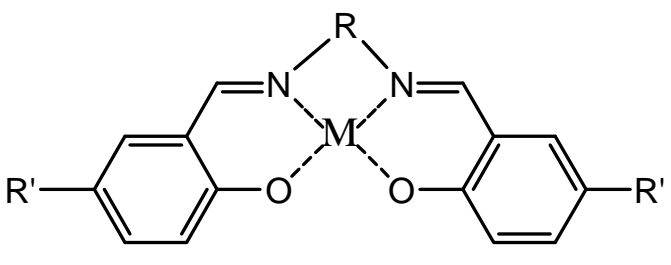

$\mathrm{I}_{3}^{-}-2$

\subsubsection{Salens}

The term "salen" is the abbreviation of the name of a popular chelating ligand used in coordination chemistry and homogeneous catalysis, i. e. salicylic aldehyde and ethylenediamine.

Salen $\mathrm{H}_{2}$ forms complexes with most transition metals, where in most cases the metal takes a square pyramidal or octahedral coordination, $\mathrm{M}($ salen$) \mathrm{L}$ and $\mathrm{M}($ salen$) \mathrm{L}_{2}$. Examples include $\mathrm{VO}($ salen) and Co(salen)Cl(pyridine).

Numerous salen-derivatives are known, e.g. the ligand abbreviated "Salph" is derived from the condensation of 1,2-phenylenediamine and salicyaldehyde [173]. Table 2 shows a number of reported membrane sensors based on salens and their complexes. Chemical structures of some salens are shown in Fig. 16.

Table 2. A number of reported potentiometric membrane sensors based on salen.

\begin{tabular}{|c|c|c|c|c|c|}
\hline Cation & Ionophore & $\begin{array}{c}\text { Slope } \\
\left(\mathrm{mV} \text { decade }^{-1}\right)\end{array}$ & $\begin{array}{c}\text { Linear Range } \\
\text { (M) }\end{array}$ & $\begin{array}{c}\text { Most Important } \\
\text { Interfering ions } \\
\left(\log K_{\text {sel }}>-2\right) \\
\end{array}$ & Ref. \\
\hline $\mathrm{NO}_{2}^{-}-1$ & Co(II)-Salen & -58.2 & $10^{-6}-10^{-1}$ & - & 174 \\
\hline $\mathrm{HPO}_{4}{ }^{2-}-1$ & Vanadyl salen & -28.8 & $1.0 \times 10^{-1}-5.0 \times 10^{-6}$ & - & 175 \\
\hline $\mathrm{HPO}_{4}{ }^{2-}-2$ & $\begin{array}{l}\text { oxo-molybdenum } \\
\text { methyl-salen }\end{array}$ & -28.6 & $1.0 \times 10^{-1}-4.0 \times 10^{-7}$ & - & 176 \\
\hline $\mathrm{HPO}_{4}{ }^{2-}-3$ & $\begin{array}{l}\text { oxo-molybdenum } \\
\text { methyl-salen (MS) }\end{array}$ & -28.6 & $1.0 \times 10^{-1}-4.0 \times 10^{-7}$ & - & 177 \\
\hline $\mathrm{Br}^{-}-1$ & iron(III)-salen (IS) & -59.0 & $7.0 \times 10^{-6}-1.0 \times 10^{-1}$ & $\mathrm{SCN}^{-}, \mathrm{I}^{-}, \mathrm{Cl}^{-}$ & 178 \\
\hline $\mathrm{I}^{-}-1$ & salen-Mn(II) & -59.0 & $1.0 \times 10^{-5}-3.4 \times 10^{-1}$ & $\mathrm{CN}^{-}$ & 179 \\
\hline $\mathrm{I}^{-}-2$ & Cerium-salen & -57.5 & $5.0 \times 10^{-2}-8.0 \times 10^{-6}$ & $\mathrm{SCN}^{-}$ & 180 \\
\hline $\mathrm{I}_{3}{ }^{-}-1$ & Mercury-salen & $-59.0 \pm 0.5$ & $5.0 \times 10^{-8}-1.0 \times 10^{-2}$ & - & 181 \\
\hline
\end{tabular}


Figure 16. Structures of two salens used in construction of some anion selective membrane sensors.<smiles>COc1ccccc1N1Oc2ccccc2OC(=O)N=C(O)CC1=O</smiles>

$\mathrm{HPO}_{4}{ }^{2-}-3$<smiles>C1=N\C=N/COc2ccccc2/1</smiles>

$\mathrm{NO}_{2}{ }^{-}-1$

\subsubsection{Salophen}

Salophen or acetylparamidophenyl salicylate is a Schiff's base with non-toxic properties, which is an effective substitute for salicylic acid. Table 3 shows a number of reported membrane sensors based on salophens and their complexes.

Table 3. A number of reported potentiometric membrane sensors based on salophen.

\begin{tabular}{|c|c|c|c|c|c|}
\hline Cation & Ionophore & $\begin{array}{l}\text { Slope } \\
\left(\mathrm{mV} \text { decade }^{-1}\right)\end{array}$ & $\begin{array}{l}\text { Linear Range } \\
\text { (M) }\end{array}$ & $\begin{array}{l}\text { Most Important } \\
\text { Interfering ions } \\
\left(\log K_{\text {sel }}>-2\right)\end{array}$ & Ref. \\
\hline $\mathrm{Al}^{+3}-1$ & $\begin{array}{l}\text { NM-bis(salicyl- } \\
\text { idene)-1,2-phenylene- } \\
\text { diamine (salophen) }\end{array}$ & 20.1 & $8.0 \times 10^{-7}-3.0 \times 10^{-2}$ & $\mathrm{Cu}^{2+}, \mathrm{Cr}^{3+}$ & 182 \\
\hline $\mathrm{NO}_{2}^{-}-1$ & Co(II)-salophen & -59.8 & $10^{-6}-10^{-1}$ & - & 183 \\
\hline $\mathrm{NO}_{2}^{-}-2$ & Uranyl salophen & 56.2 & $10^{-3}-10^{-1}$ & - & 184 \\
\hline $\mathrm{H}_{2} \mathrm{PO}_{4}^{-}-1$ & Uranyl salophenes & -59 & $10^{-4}-10^{-1}$ & - & 185 \\
\hline $\mathrm{HPO}_{4}{ }^{2-}-2$ & vanadyl salophen & -24.3 & $10^{-1}-10^{-6}$ & - & 186 \\
\hline $\mathrm{F}^{-}-1$ & $\begin{array}{l}\text { uranyl salophen } \\
\text { derivatives }\end{array}$ & -56 & $1.0 \times 10^{-4}-1.0 \times 10^{-1}$ & - & 187 \\
\hline $\mathrm{I}^{-}-1$ & cobalt-salophen & -58.9 & $5.0 \times 10^{-7}-1.0 \times 10^{-1}$ & - & 188 \\
\hline
\end{tabular}

\subsubsection{Hydrazones}

Hydrazones are a class of organic compounds with the general structure of $\mathrm{R}_{2} \mathrm{C}=\mathrm{NNR}_{2}$ (Figure 17) which are related to ketones and aldehydes by the replacement of the oxygen with the $\mathrm{NNR}_{2}$ functional group. These compounds are commonly formed through the reaction of hydrazine on ketones or aldehydes. Table 4 shows a number of reported membrane sensors based on hydrazone derivatives. 
Figure 17. The basic structure of a hydrazone.<smiles>[R]C([R])=NN</smiles>

Table 4. A number of reported potentiometric membrane sensors based on hydrazone derivatives.

\begin{tabular}{|c|c|c|c|c|c|}
\hline Cation & Ionophore & $\begin{array}{l}\text { Slope } \\
\left(\mathrm{mV} \text { decade }^{-1}\right)\end{array}$ & $\begin{array}{l}\text { Linear Range } \\
\text { (M) }\end{array}$ & \begin{tabular}{lr}
\multicolumn{2}{l}{ Most Important } \\
Interfering & ions \\
$(\log$ Ksel $>-2)$ & \\
\end{tabular} & Ref. \\
\hline $\mathrm{La}^{3+}-1$ & $\begin{array}{l}N, N^{\prime} \text {-adipylbis(5-phenyl- } \\
\text { azosalicylaldehyde } \\
\text { hydrazone) }\end{array}$ & 19.4 & $10^{-6}-10^{-2}$ & $\mathrm{Yb}^{3+}$ & 189 \\
\hline $\mathrm{La}^{3+}-2$ & $\begin{array}{l}\text { Bis(2-methylbenzaldehyde)- } \\
\text { butane-2,3-dihydrazone } \\
\text { (TDSB) }\end{array}$ & 19.8 & $\begin{array}{l}1.0 \times 10^{-5}-1.0 \times \\
10^{-1}\end{array}$ & $\mathrm{Cu}^{2+}, \mathrm{Ce}^{3+}, \mathrm{Pr}^{3+}$ & 190 \\
\hline $\mathrm{La}^{3+}-3$ & $\begin{array}{l}N \text {-[hexahydrocyclopenta- } \\
\text { pyrol-2((1H)yl)amino]- } \\
\text { carbonyl]-4-methylbenzene } \\
\text { sulfonamide }\end{array}$ & 20.1 & $10^{-6}-10^{-1}$ & $\mathrm{Sm}^{3+}, \mathrm{Ce}^{3+}$ & 191 \\
\hline $\mathrm{La}^{3+}-4$ & $\begin{array}{l}\text { 3-hydroxy- } N \text { '-(pyridin-2- } \\
\text { ylmethylene)-2-naphtho- } \\
\text { hydrazide (HPMN) }\end{array}$ & 19.2 & $10^{-7}-10^{-2}$ & $\mathrm{Yb}^{3+}, \mathrm{Ce}^{3+}$ & 192 \\
\hline $\mathrm{La}^{3+}-5$ & $\begin{array}{l}\text { 8-amino- } N \text {-(2-hydroxy- } \\
\text { benzylidene)naphthylamine } \\
\text { (AIP) }\end{array}$ & $20.3 \pm 0.3$ & $\begin{array}{l}1.0 \times 10^{-7}-1.0 \times \\
10^{-1}\end{array}$ & $\mathrm{Pr}^{3+}$ & 193 \\
\hline $\mathrm{La}^{3+}-6$ & $\begin{array}{l}N^{\prime} \text {-(1-pyridin-2-yl- } \\
\text { methylene)-2-furohydrazide } \\
\text { (NPYFH) }\end{array}$ & $19.2 \pm 0.6$ & $\begin{array}{l}1.0 \times 10^{-6}-1.0 \times \\
10^{-1}\end{array}$ & $\mathrm{Sm}^{3+}, \mathrm{Nd}^{3+}$ & 194 \\
\hline $\operatorname{Pr}^{+3}-1$ & $\begin{array}{l}N \text {-(pyridin-2-yl- } \\
\text { methylene)benzohydrazide }\end{array}$ & 21.1 & $10^{-2}-10^{-6}$ & $\mathrm{Sm}^{3+}, \mathrm{Er}^{3+}$ & 195 \\
\hline $\mathrm{Nd}^{+3}-1$ & $\begin{array}{l}N \text {-(2-furylmethylene) } \\
\text { pyridine-2,6-diamine }\end{array}$ & 19.6 & $10^{-5}-10^{-2}$ & $\mathrm{La}^{3+}, \mathrm{Gd}^{3+}, \mathrm{Sm}^{3+}$ & 196 \\
\hline $\mathrm{Nd}^{+3}-2$ & $\begin{array}{l}\text { 2-\{[(6-aminopyridin- } \\
\text { 2-yl)imino]methyl }\} \text { phenol }\end{array}$ & 19.6 & $10^{-5}-10^{-2}$ & $\mathrm{La}^{3+}, \mathrm{Sm}^{3+}$ & 197 \\
\hline $\mathrm{Sm}^{3+}-1$ & $\begin{array}{l}\text { 3-\{[2-oxo-1 }(2 \mathrm{H}) \text { - } \\
\text { acenaphthylenyliden]amino }\} \\
\text {-2-thioxo-1,3-thiazolidin-4- } \\
\text { one }\end{array}$ & 19.3 & $10^{-6}-10^{-1}$ & - & 198 \\
\hline $\mathrm{Eu}^{3+}-1$ & $\begin{array}{l}\text { bis(thiophenol)butane2,3- } \\
\text { dihydrazone }\end{array}$ & 19.8 & $\begin{array}{l}1.0 \times 10^{-5}-1.0 \times \\
10^{-2}\end{array}$ & $\mathrm{La}^{3+}, \mathrm{Gd}^{3+}, \mathrm{Sm}^{3+}$ & 199 \\
\hline $\mathrm{Er}^{+3}-1$ & $\begin{array}{l}\text { Pyridine-2-carbaldehyde-2- } \\
\text { (4-methyl-1,3-benzothiazol- } \\
\text { 2-yl)hydrazone }\end{array}$ & 21.8 & $10^{-5}-10^{-2}$ & $\mathrm{Sm}^{3+}, \mathrm{Tm}^{3+}, \mathrm{Gd}^{3+}$ & 200 \\
\hline
\end{tabular}


Table 4. Cont.

\begin{tabular}{|c|c|c|c|c|c|}
\hline $\mathrm{Er}^{+3}-2$ & $\begin{array}{l}N^{\prime} \text {-(2-Hydroxy-1,2- } \\
\text { diphenyl-ethylidene) } \\
\text { benzohydrazide (HDEBH) } \\
\end{array}$ & 21.0 & $10^{-7}-10^{-2}$ & $\mathrm{Ho}^{3+}$ & 201 \\
\hline $\mathrm{Er}^{+3}-3$ & $\begin{array}{l}N ' \text {-(2-Hydroxy-1,2-diphenyl- } \\
\text { ethylidene) benzohydrazide } \\
\text { (HDEBH) }\end{array}$ & $\begin{array}{l}17.5 \\
\text { (microelectrode) }\end{array}$ & $1.0 \times 10^{-3}-3.0 \times 10^{-10}$ & - & 202 \\
\hline $\mathrm{Tm}^{+3}-1$ & $\begin{array}{l}\text { thiophene-2-carbaldehyde- } \\
\text { (7-methyl-1,3-benzothiazol- } \\
\text { 2-yl)hydrazone }\end{array}$ & 19.5 & $10^{-5}-10^{-2}$ & $\mathrm{Er}^{3+}$ & 203 \\
\hline $\mathrm{Yb}^{+3}-1$ & $\begin{array}{l}\text { 3-hydroxy- } N^{\prime} \text {-[(2-hydroxy- } \\
\text { phenyl)methylene]-2- } \\
\text { naphthohydrazide }\end{array}$ & 19.2 & $10^{-7}-10^{-2}$ & $\mathrm{Nd}^{3+}, \mathrm{Pb}^{2+}, \mathrm{Gd}^{3+}$ & 204 \\
\hline $\mathrm{Hg}^{2+}-1$ & $\begin{array}{l}\text { bis(2-hydroxy- } \\
\text { benzophenone) butane-2,3- } \\
\text { dihydrazone (HBBD) }\end{array}$ & 29.7 & $\begin{array}{l}1.0 \times 10^{-6}-1.0 \times \\
10^{-1}\end{array}$ & $\mathrm{Fe}^{3+}, \mathrm{Cd}^{2+}, \mathrm{La}^{3+}$ & 205 \\
\hline $\mathrm{I}_{3}-1$ & $\begin{array}{l}\text { complex of iodine and bis(2- } \\
\text { hydroxyacetophenone)- } \\
\text { butane-2,3-dihydrazone." }\end{array}$ & $-58.99 \pm 0.3$ & $1.0 \times 10^{-2}-5.0 \times 10^{-7}$ & - & 206 \\
\hline $\mathrm{I}_{3}-2$ & $\begin{array}{l}\text { bis(2,4-dimethoxy- } \\
\text { benzaldehyde)butane-2,3- } \\
\text { dihydrazone with iodine }\end{array}$ & -60.6 & $10^{-7}-10^{-2}$ & - & 207 \\
\hline$I_{3}-3$ & $\begin{array}{l}\text { bis(2-hydroxy- } \\
\text { acetophenone)butane-2,3- } \\
\text { dihydrazone. }\end{array}$ & -58.99 & $\begin{array}{l}1.0 \times 10^{-2}-5.0 \times 10^{-} \\
7\end{array}$ & - & 208 \\
\hline
\end{tabular}

\section{Crown Ethers as Supramolecular Sensing Materials in Construction of Membrane Sensors.}

Crown ethers are macrocyclic compounds containing symmetrically distributed ether linkages in a large ring. The first crown ether, a cyclic hexaether, was accidentally discovered during the synthesis of bisphenols (Scheme 2). This compound was found to increase the dissolution of potassium permanganate in benzene and chloroform [3].

Crown ethers selectively complex metal or ammonium salts, depending on their size, number and type of heteroatom. 12-Crown-4, for example, tends to complex with $\mathrm{Li}^{+}$, while 18-crown-6 prefers $\mathrm{K}^{+}$. The resulting metal complexes, in which crown ether acts as the host and the metal cation is the guest, fall into the class of host-guest chemistry. 
Scheme 2. Synthesis method of the first crown ether.<smiles>Oc1ccccc1OC1CCCCO1</smiles><smiles>ClCCOCCCl</smiles>

has some impurity of<smiles>Oc1ccccc1O</smiles>

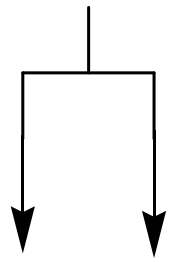<smiles>c1ccc2c(c1)OCCOCCOc1ccccc1OCCOCCO2</smiles>

Byproduct<smiles>Oc1ccccc1OCCOCCOc1ccccc1O</smiles>

Product

\subsection{Classes of Crown Ethers}

The selectivity of the complexes of crown ethers is based on the size of the substrate and the ring size and distribution of the donor atoms in the crown. It is obvious that crown ethers of larger inner cores tend to bind larger ions. It should be noted that the relative flexibility of the crown rings leads to some degree of structural freedom during complexation. This is undesired with respect to selective binding and hence there have been efforts to improve the crown ether structures (Figure 18). Table 5 summarizes the cavity sizes of some simple crown ethers and cryptands [3].

Table 5. Cavity size of some simple crown ethers and cryptands [209,210].

\begin{tabular}{|l|l|}
\hline Compound & Size of the Cavity $(\AA)$ \\
\hline 15-crown-5 & $1.7-2.2$ \\
18-crown-6 & $2.6-3.2$ \\
21-crown-7 & $3.4-4.3$ \\
Cryptand 111 & 1.0 \\
Cryptand 211 & 1.6 \\
Cryptand 221 & 2.2 \\
Cryptand 222 & 2.8 \\
Cryptand 322 & 3.6 \\
Cryptand 332 & 4.2 \\
\hline Cryptand 333 & 4.8 \\
\hline
\end{tabular}


Figure 18. Structures of some crwon ethers and cryptands.<smiles>C1COCCOCCOCCOCCOCCO1</smiles><smiles>C1CCOCCOCCOCCOCCOC1</smiles>

Crown ether<smiles>COCCOCCN1CCOCCOCCOCCOCCOCC1</smiles>

Larriet crown ether<smiles>C1COCCN2CCOCCOCCN(CCOCCO1)CCOCCOCC2</smiles><smiles>C1COCCN2CCOCCOCCN(CCO1)CCOCC2</smiles>

Cryptand

Cryptands have a rigid structure which does not allow the flexible structural changes observed in the case of podands and crown ethers, hence their central cavities are much more constrained, resulting in higher binding selectivities.

The selectivity of the crowns can be increased through a similar mechanism, which is the substitution of podand arms to 2D crown ether, converting them to hosts with a 3D cavity. Because the host structure, in this case, looks like a lariat (a lasso), such hosts are called lariat ethers. The spherands comprise another family incorporating a rigid cycle with a binding site pointing to the cavity inside [3]. 
Figure 19. Structures of some aza crown ethers and cryptands.
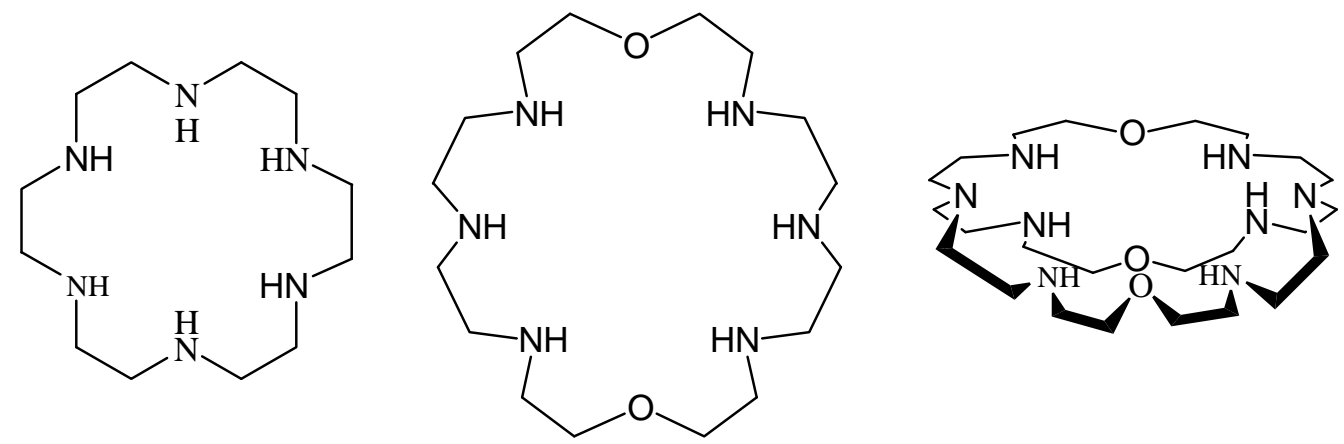

Another class of host compounds is prepared by replacing the $\mathrm{O}$ atoms of the crown ethers by nitrogen. This group is called macrocyclic polyamines. Protonated amine hosts are also capable of binding anions (Figure 19). Due to the fact that some of these compounds have elliptic shapes, they can be used for the recognition of linear anions such as the azide anion $\left(\mathrm{N}_{3}{ }^{-}\right)$.

Macrocyclic polyamines, having hydrophobic alkyl chains, can be fixed on an electrode surface to create an anion-sensing device. Macrocyclic polyamines are also known for their tendency to multivalent phosphates.

Another group of these compounds are crown ethers with sulfur atoms, which are called as thiacrowns. These groups together with the macrocyclic polyamines tend to complex soft ions such as transition metal ions, on the contrary to crown ethers which prefer hard species like alkali metal ions.

\subsection{Controlling the recognition ability of a crown ethers}

If the recognition ability of crown ethers can be controlled, novel kinds of hosts can be designed. Fig. 20 shows a biological example, in which the host consists of oligoethylene glycol with bipyridyl units at both ends, wherein the bipyridine unit and the oligoethylene glycol have different complexation tendencies. Two bipyridine units sandwich a copper ion, inducing a change in the oligoethylene chain from a linear to a pseudo-cyclic (podand) form. As a result, an alkali ion can be complexed by the oligoethylene loop. This means that the binding properties of a binding site of the host are adjusted by the bonding of the other to a copper ion. But it would be more convenient to control the complexation behavior through physical stimuli such as light and electricity, which have no interfering chemical roles on the system [3].

As another method of control, the electron-driven recognition has been suggested. The binding ability of the hosts in Figure 21 changes as a result of redox reactions between thiol and disulfide groups [3]. 
Figure 20. Controlling the recognition ability of crown ethers through an external stimulus [3].<smiles>COc1ccc(-c2ccc(-c3cc(-c4ccc(OC)cc4)cc(COCCOCCOCCOCCOCCOCc4cc(-c5ccc(OC)cc5)cc(-c5cc(-c6ccc(OC)cc6)ccn5)n4)n3)cc2)cc1</smiles><smiles>COc1ccc(-c2cc(C)nc(OCCOCCOCCOCCOCCOCCOCc3cc(-c4ccc(OC)cc4)cc(-c4nc(-c5ccc(OC)cc5)cc(-c5ccc(OC)cc5)n4)n3)c2)cc1</smiles>

Figure 21. Loss of binding ability through redox reactions between thiol and disulfide groups [3].
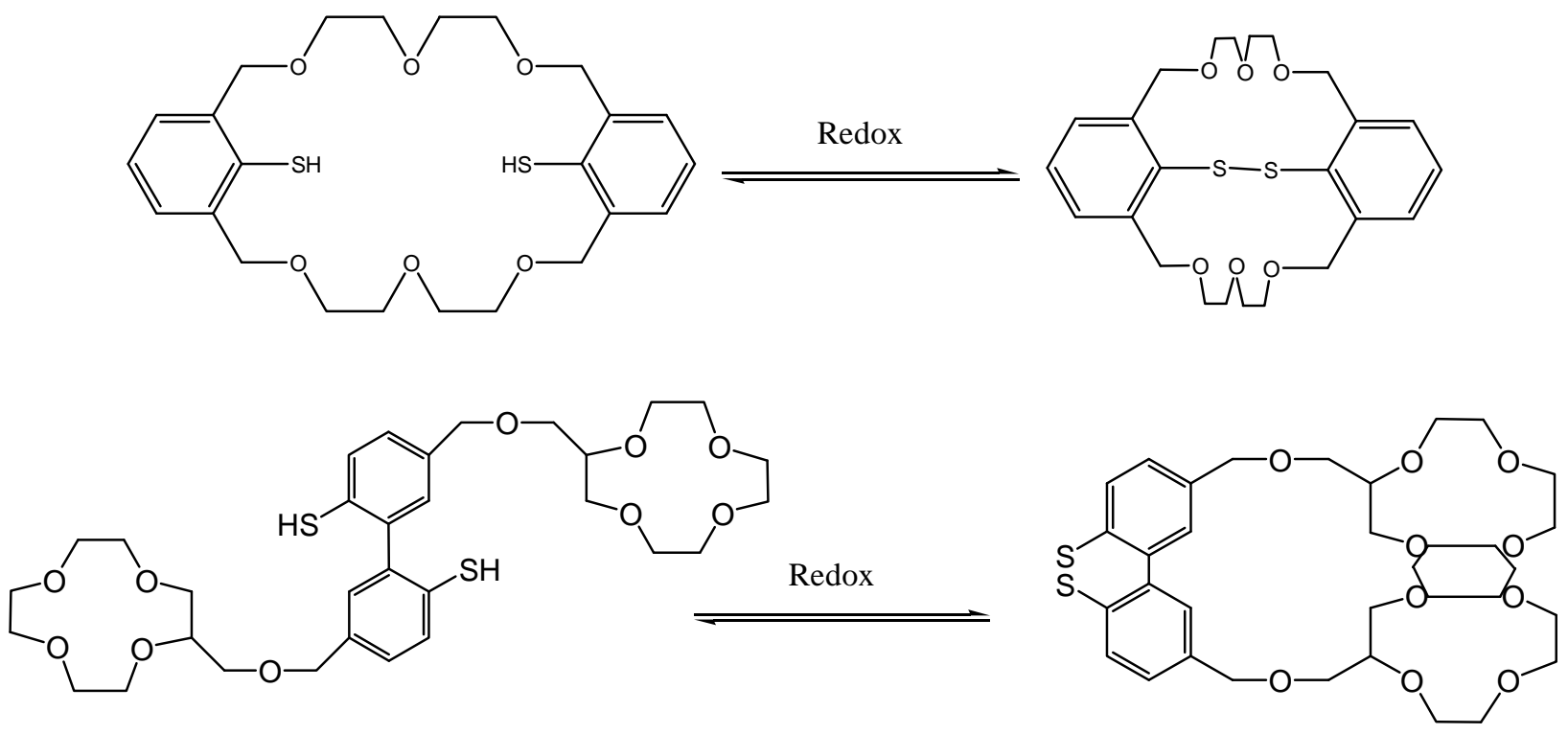

Table 6 shows a number of potentiometric sensors based on crown ethers as sensing materials. 
Table 6. A number of reported potentiometric membrane sensors based on crown ethers.

\begin{tabular}{|c|c|c|c|c|c|}
\hline Cation & Ionophore & $\begin{array}{c}\text { Slope } \\
\text { (mV decade } \\
\text { 1) }\end{array}$ & $\begin{array}{c}\text { Linear Range } \\
\text { (M) }\end{array}$ & $\begin{array}{c}\text { Most Important } \\
\text { Interfering ions } \\
\left(\log K_{\text {sel }}>-2\right) \\
\end{array}$ & Ref. \\
\hline $\mathrm{Li}^{+}-1$ & Decalino-14-Crown-4 & 58 & $1 \times 10^{-6}-1$ & $\mathrm{Na}^{+}$ & 211 \\
\hline $\mathrm{Li}^{+}-2$ & $\begin{array}{l}\text { Tnf-Based 16-Crown-4 } \\
\text { Derivatives }\end{array}$ & 58.2 & $1 \times 10^{-5}-1 \times 10^{-1}$ & $\mathrm{Na}^{+}, \mathrm{NH}_{4}^{+}$ & 212 \\
\hline $\mathrm{Li}^{+}-3$ & $\begin{array}{l}\text { Lipophilic Crown-4 } \\
\text { Derivatives }\end{array}$ & 58 & $10^{-4}-10^{-1}$ & $\mathrm{Na}^{+}, \mathrm{K}^{+}, \mathrm{NH}_{4}^{+}$ & 213 \\
\hline $\mathrm{Li}^{+}-4$ & 16-crown-4 derivatives & 59.7 & $7 \times 10^{-4}-1.5 \times 10^{-3}$ & - & 214 \\
\hline $\mathrm{Na}^{+}-1$ & $\begin{array}{l}\text { Bis[(12-crown-4)methyl] } \\
\text { methyl(dodecyl)malonate } \\
\text { [bis(12-crown-4)] and } \\
\text { polyether-amide } \\
\text { compounds (ETH 157, } \\
\text { ETH 2120) }\end{array}$ & 54 & $1.0 \times 10^{-4}-1.0 \times 10^{-1}$ & $\mathrm{~K}^{+}$ & 215 \\
\hline $\mathrm{Na}^{+}-2$ & $\begin{array}{l}\text { Bis(10-crown-3)-hexa- } \\
\text { methylenebis(3,6,10- } \\
\text { trioxacycloundecane) }\end{array}$ & 54 & $1 \times 10^{-5}-1$ & $\mathrm{~K}^{+}$ & 216 \\
\hline $\mathrm{Na}^{+}-3$ & $\begin{array}{l}\text { Crown-bridged } \\
\text { calix[4]quinones }\end{array}$ & 54 & $1.0 \times 10^{-4}-1.0 \times 10^{-1}$ & $\mathrm{~K}^{+}$ & 217 \\
\hline $\mathrm{Na}^{+}-4$ & $\begin{array}{l}\text { dibenzopyridino-18- } \\
\text { crown-6 }\end{array}$ & 51.2 & $1.0 \times 10^{-4}-1.0 \times 10^{-1}$ & $\mathrm{~Pb}^{2+}, \mathrm{NH}_{4}^{+}, \mathrm{Cs}^{+}$ & 218 \\
\hline $\mathrm{Na}^{+}-5$ & $\begin{array}{l}\text { 1-methyl-1-vinyl-14- } \\
\text { crown-5 }\end{array}$ & 55.0 & $3.16 \times 10^{-6}-1.0 \times 10^{-1}$ & $\mathrm{~K}^{+}$ & 219 \\
\hline $\mathrm{K}^{+}-1$ & $\begin{array}{l}\text { styrene/4(-vinylbenzo-24- } \\
\text { crown-8) copolymer }\end{array}$ & 58 & $1.0 \times 10^{-6} 1.0 \times 10^{-1}$ & - & 220 \\
\hline $\mathrm{K}^{+}-2$ & $\begin{array}{l}\text { Bis(crown ether) } \\
\text { ionophore containing two } \\
\text { benzo-15-crown-5 moieties }\end{array}$ & 57 & $5.0 \times 10^{-6} 1.0 \times 10^{-1}$ & $\mathrm{NH}_{4}^{+}, \mathrm{Na}^{+}, \mathrm{Cs}^{+}$ & 221 \\
\hline $\mathrm{Rb}^{+}-1$ & $\begin{array}{l}\text { crown ethers incorporating } \\
\text { anthraquinone, benzo- } \\
\text { quinone, and 1,4- } \\
\text { dimethoxybenzene }\end{array}$ & 54.7 & $1.0 \times 10^{-5}-1.0 \times 10^{-1}$ & $\begin{array}{l}\mathrm{Na}^{+}, \mathrm{K}^{+}, \mathrm{Mg}^{2+}, \mathrm{NH}_{4}^{+} \\
, \mathrm{Li}^{+}\end{array}$ & 222 \\
\hline $\mathrm{Rb}^{+}-2$ & $\begin{array}{l}\text { dibenzo-21-crown-7 } \\
\text { (DB21C7) }\end{array}$ & 57.8 & $1.0 \times 10^{-5}-5.0 \times 10^{-2}$ & - & 223 \\
\hline $\mathrm{Cs}^{+}-1$ & upper-rim calix[4]crown & 48 & $1 \times 10^{-6}-1 \times 10^{-1}$ & $\mathrm{Rb}^{+}$ & 224 \\
\hline $\mathrm{Cs}^{+}-2$ & $\begin{array}{l}\text { calix[4]arene } \\
\text { dibenzocrown ether }\end{array}$ & 58.5 & $1 \times 10^{-6}-1 \times 10^{-1}$ & $\mathrm{Na}^{+}, \mathrm{K}^{+}$ & 225 \\
\hline $\mathrm{Cs}^{+}-3$ & $\begin{array}{l}\text { 1,3-alternate } \\
\text { thiacalix[4]biscrown-6,6 }\end{array}$ & 57.6 & $1.0 \times 10^{-6}$ to $3.2 \times 10^{-2}$ & $\mathrm{~K}^{+}$ & 226 \\
\hline $\mathrm{Be}^{2+}-1$ & benzo-9-crown-3 & 28 & $2.5 \times 10^{-6}-4.0 \times 10^{-3}$ & - & 227 \\
\hline $\mathrm{Be}^{2+}-2$ & $\begin{array}{l}\text { 2,4- } \\
\text { dinitrophenylhydrazineben } \\
\text { zo-9-crown-3 }\end{array}$ & 29.5 & $1.0 \times 10^{-1}-4.0 \times 10^{-7}$ & - & 228 \\
\hline $\mathrm{Be}^{2+}-3$ & naphto-9-crown-3 & 29.5 & $1.0 \times 10^{-1}-8.0 \times 10^{-6}$ & - & 229 \\
\hline
\end{tabular}


Table 6. Cont.

\begin{tabular}{|c|c|c|c|c|c|}
\hline $\mathrm{Be}^{2+}-4$ & $\begin{array}{l}\text { 2,3,5,6,8,9-hexahydro- } \\
\text { 1,4,7,10-benzotetra } \\
\text { oxacyclododecine-12- } \\
\text { carbaldehyde-12-(2,4- } \\
\text { dinitrophenyl)hy }\end{array}$ & 29.9 & $1.0 \times 10^{-7}-1.0 \times 10^{-1}$ & $\mathrm{Na}^{+}, \mathrm{Ca}^{+2}, \mathrm{Li}^{+}$, & 230 \\
\hline $\mathrm{Be}^{2+}-5$ & $\begin{array}{l}\text { 2,6-diphenyl-4-benzo-9- } \\
\text { crown-3-pyridine }\end{array}$ & 29.6 & $1.0 \times 10^{-7}-1.0 \times 10^{-1}$ & $\mathrm{Mg}^{+2}, \mathrm{Ca}^{+2}, \mathrm{~K}^{+}, \mathrm{Na}^{+}$ & 231 \\
\hline $\mathrm{Be}^{2+}-6$ & $\begin{array}{l}\text { 2,3,5,6,8,9-hexahydro- } \\
\text { naphto [2,3-b]- }[1,4,7,10] \\
\text { tetraoxacyclododecine }\end{array}$ & 29.8 & $1.0 \times 10^{-8}-1.0 \times 10^{-2}$ & - & 232 \\
\hline $\mathrm{Be}^{2+}-7$ & $\begin{array}{l}\text { a derivative of benzo-9- } \\
\text { crown-3 }\end{array}$ & 29.6 & $1.0 \times 10^{-6}-1.0 \times 10^{-1}$ & - & 233 \\
\hline $\mathrm{Be}^{2+}-8$ & $\begin{array}{l}\text { a derivative of benzo-9- } \\
\text { crown-3 }\end{array}$ & 29.5 & $1.0 \times 10^{-7}-1.0 \times 10^{-1}$ & - & 234 \\
\hline $\mathrm{Mg}^{2+}-1$ & benzo-15-crown-5 & 31.0 & $1.0 \times 10^{-5}-1.0 \times 10^{-1}$ & $\mathrm{~K}^{+}, \mathrm{Cd}^{2+} \cdot \mathrm{Mg}^{2+}$ & 235 \\
\hline $\mathrm{Sr}^{+2}-1$ & $\begin{array}{l}\text { dibenzo-24-crown-8(I) and } \\
\text { 4-tert-butylcalix[8]arene }\end{array}$ & 30 & $1.4 \times 10^{-5}-1.0 \times 10^{-1}$ & $\mathrm{Na}^{+}$ & 236 \\
\hline $\mathrm{Sr}^{+2}-2$ & $\begin{array}{l}\text { benzo-substituted } \\
\text { macrocyclic diamides }\end{array}$ & 30 & $3.2 \times 10^{-5}-1.0 \times 10^{-1}$ & - & 237 \\
\hline $\mathrm{In}^{3+}-1$ & $\begin{array}{l}\text { 15-crown-5 (15C5), } \\
\text { dicyclohexano-18-crown-6 } \\
\text { (DCH18C6) }\end{array}$ & 20.1 & $3.8 \times 10^{-5}-5.0 \times 10^{-2}$ & - & 238 \\
\hline $\mathrm{Tl}^{3+}-1$ & dibenzyldiaza-18-crown-6 & 56.9 & $1.0 \times 10^{-5}-1.0 \times 10^{-1}$ & $\mathrm{Cd}^{2+}, \mathrm{Hg}^{2+}, \mathrm{Ag}^{+}$ & 239 \\
\hline $\mathrm{Sn}^{2+}-1$ & $\begin{array}{l}\text { dibenzo-18-crown- } \\
\text { 6(DB18C6) }\end{array}$ & 27.5 & $1.0 \times 10^{-6}-1.0 \times 10^{-2}$ & - & 240 \\
\hline $\mathrm{Pb}^{2+}-1$ & $\begin{array}{l}\text { monobenzo-15-crown-5 } \\
\text { (MB15C5), MB15C5- } \\
\text { phosphotungstic acid } \\
\text { (PW) and MB15C5- } \\
\text { phosphomolybdic acid } \\
\text { (PMo) }\end{array}$ & 30 & $1 \times 10^{-1}-1 \times 10^{-5}$ & $\mathrm{Ag}^{2+}, \mathrm{Hg}^{2+}$ & 241 \\
\hline $\mathrm{Pb}^{2+}-2$ & dibenzodiaza-15-crown-4 & 29 & $5.0 \times 10^{-6}-1.0 \times 10^{-2}$ & - & 242 \\
\hline $\mathrm{Pb}^{2+}-3$ & 4'-vinylbenzo-15-crown-5 & 59 & $4.0 \times 10^{-3}-1.0 \times 10^{-6}$ & $\mathrm{~K}^{+}$ & 243 \\
\hline $\mathrm{Pb}^{2+}-4$ & $\begin{array}{l}\text { dithiophenediazacrown } \\
\text { ether derivatives. }\end{array}$ & 29.2 & $10^{5.0}-10^{2.7}$ & $\mathrm{Hg}^{2+}$ & 244 \\
\hline $\mathrm{Pb}^{2+}-5$ & $\begin{array}{l}\text { 1,10-dibenzyl-1,10-diaza- } \\
\text { 18-crown-6 }\end{array}$ & 29.1and 28.9 & $5.0 \times 10^{-6}-10^{-1}$ & $\mathrm{Cd}^{2+}, \mathrm{Cu}^{2+}$ & 245 \\
\hline $\mathrm{Pb}^{2+}-6$ & $\begin{array}{l}\text { 18-membered thiacrown } \\
\text { derivative }\end{array}$ & 29.0 & $1.0 \times 10^{-6}-8.0 \times 10^{-3}$ & - & 246 \\
\hline $\mathrm{Pb}^{2+}-7$ & $\begin{array}{l}\text { N,N'-dimethylcyanodiaza- } \\
\text { 18-crown-6 }\end{array}$ & 29 & $10^{-7}-10^{-2}$ & - & 247 \\
\hline $\mathrm{La}^{3+}-1$ & monoaza-12-crown-4 & $20.5 \pm 1.0$ & $3.16 \times 10^{-5}-1.0 \times 10^{-1}$ & $\begin{array}{l}\mathrm{Pb}^{2+}, \mathrm{Mg}^{2+}, \mathrm{Ca}^{2+}, \\
\mathrm{Cu}^{2+}, \mathrm{Zn}^{2+}, \mathrm{Cd}^{2+} \\
\mathrm{Cr}^{3+}, \mathrm{Ce}^{3+}, \mathrm{Eu}^{3+}\end{array}$ & 248 \\
\hline $\mathrm{Ce}^{3+}-1$ & 1,3,5-trithiane & 19.2 & $4.7 \times 10^{-4}-2.5 \times 10^{-8}$ & $\mathrm{La}^{3+}$ & 249 \\
\hline
\end{tabular}


Table 6. Cont.

\begin{tabular}{|c|c|c|c|c|c|}
\hline $\mathrm{Cr}^{3+}-1$ & $\begin{array}{l}\text { Different ionophoric } \\
\text { species, viz.: 18-crown-6 } \\
\text { (18C6), dibenzo-18-crown- } \\
6 \text { (DB18C6) and } \\
\text { calix[6]arene (CAX) }\end{array}$ & 18.5and 20 & $1.0 \times 10^{-5}-1.0 \times 10^{-1}$ & $\mathrm{~Pb}^{2+}$ and $\mathrm{Na}^{+}$ & 250 \\
\hline $\mathrm{Fe}^{3+}-1$ & $\begin{array}{l}\text { benzo-18-crown-6 crown } \\
\text { ether }\end{array}$ & $15.7 \pm 1$ & $1 \times 10^{-6}-1.0 \times 10^{-1}$ & - & 251 \\
\hline $\mathrm{Co}^{2+}-1$ & $\begin{array}{l}\text { benzo-substituted } \\
\text { macrocyclic diamide }\end{array}$ & 29 & $2.0 \times 10^{-6}-1.2 \times 10^{-2}$ & - & 252 \\
\hline $\mathrm{Co}^{2+}-2$ & $\begin{array}{l}\text { dibenzopyridino- } \\
\text { substituted macrocyclic } \\
\text { diamide }\end{array}$ & 29 & $7.0 \times 10^{-7}-1.0 \times 10^{-2}$ & - & 253 \\
\hline $\mathrm{Ni}^{2+}-1$ & dibenzodiaza-15-crown-4 & 28.6 & $7.1 \times 10^{-7}-1.2 \times 10^{-2}$ & $\mathrm{Ag}^{+}, \mathrm{Pd}^{2+}$ & 254 \\
\hline $\mathrm{Cu}^{2+}-1$ & $\begin{array}{l}\text { Aza-thioether crowns } \\
\text { containing a } 1,10- \\
\text { phenanthroline sub-unit }\end{array}$ & 30 & $1 \times 10^{-5}-2 \times 10^{-1}$ & $\mathrm{La}^{+3}$ & 255 \\
\hline $\mathrm{Cu}^{2+}-2$ & $\begin{array}{l}\text { 23-member macrocyclic } \\
\text { diamide }\end{array}$ & 30 & $3.2 \times 10^{-5}-1.0 \times 10^{-1}$ & - & 256 \\
\hline $\mathrm{Ag}^{+}-1$ & $\begin{array}{l}\text { Lipophilic pyrrole-based } \\
\text { tetraazacrown ether }\end{array}$ & 55 & $1.0 \times 10^{-5}-1.0 \times 10^{-1}$ & $\mathrm{Hg}^{2+}$ & 257 \\
\hline $\mathrm{Ag}^{+}-2$ & $\begin{array}{l}\text { diaza-18-crown-6, } \\
\text { containing two oxime } \\
\text { donor groups } \\
\end{array}$ & 59.5 & $1.0 \times 10^{-5}-1.0 \times 10^{-2}$ & - & 258 \\
\hline $\mathrm{Ag}^{+}-3$ & hexathia-18-crown-6 & 59 & $6.0 \times 10^{-6}-3.2 \times 10^{-3}$ & - & 259 \\
\hline $\mathrm{Ag}^{+}-4$ & $\begin{array}{l}\text { Aza-thioether crowns } \\
\text { containing a } 1,10- \\
\text { phenanthroline sub-unit }\end{array}$ & 59.4 and 59.1 & $\begin{array}{l}1.0 \times 10^{-5}-1.0 \times 10^{-1} \\
\text { and } \\
5.0 \times 10^{-8}-4.0 \times 10^{-2}\end{array}$ & $\mathrm{Cu}^{2+}, \mathrm{Tl}^{+}$ & 260 \\
\hline $\mathrm{Ag}^{+}-5$ & $\begin{array}{l}\text { exocyclic sulfur and } \\
\text { selenium ligands based on } \\
\text { calix[4]arenes and crown } \\
\text { ethers }\end{array}$ & 56.0 & $1.0 \times 10^{-5}-1.0 \times 10^{-2}$ & $\mathrm{Hg}^{2+}$ & 261 \\
\hline $\mathrm{Ag}^{+}-6$ & $\begin{array}{l}\text { 5,11,17,23-tetra-tert-butyl- } \\
\text { 25,27-dihydroxy- } \\
\text { calix[4]arene-thiacrown-4 }\end{array}$ & $53.8 \pm 1.6$ & $1.0 \times 10^{-6}-1.0 \times 10^{-2}$ & $\mathrm{Hg}^{2+}$ & 262 \\
\hline $\mathrm{Ag}^{+}-7$ & $\begin{array}{l}\text { 1,10-phenanthroline sub- } \\
\text { unit }\end{array}$ & 56 & $1.0 \times 10^{-5}-1.0 \times 10^{-1}$ & $\mathrm{Hg}^{2+}$ & 263 \\
\hline $\mathrm{Zn}^{2+}-1$ & cryptand C2(B)22 & 24 & $5.0 \times 10^{-5}-5.0 \times 10^{-2}$ & $\mathrm{Na}^{+}$ & 264 \\
\hline $\mathrm{Zn}^{2+}-2$ & dibenzo-24-crown-8 & $29.0 \pm 0.5$ & $9.2 \times 10^{-5}-1.0 \times 10^{-1}$ & - & 265 \\
\hline $\mathrm{Zn}^{2+}-3$ & $\begin{array}{l}\text { benzo-substituted } \\
\text { macrocyclic diamide }\end{array}$ & 29.0 & $9.0 \times 10^{-5}-1.0 \times 10^{-1}$ & - & 266 \\
\hline $\mathrm{Cd}^{2+}-1$ & dicyclohexano-24-crown-8 & $30.0 \pm 1.0$ & $3.0 \times 10^{-5}-1.0 \times 10^{-1}$ & $\mathrm{Fe}^{3+}, \mathrm{Cr}^{3+}, \mathrm{Ce}^{3+}$ & 267 \\
\hline $\mathrm{Cd}^{2+}-2$ & dicyclohexano-18-crown-6 & $29.0 \pm 1.0$ & $2.5 \times 10^{-5}-1.0 \times 10^{-1}$ & - & 268 \\
\hline $\mathrm{Cd}^{2+}-3$ & tetrathia-12-crown-4 & $29.0 \pm 1.0$ & $4 \times 10^{-7}-1.0 \times 10^{-1}$ & - & 269 \\
\hline $\mathrm{Cd}^{2+}-4$ & monoaza-18-crown-6 & 29 & $1.0 \times 10^{-5}-1.0 \times 10^{-1}$ & $\mathrm{Cu}^{2+}, \mathrm{Na}^{+}, \mathrm{Ca}^{2+}$ & 270 \\
\hline
\end{tabular}


Table 6. Cont.

\begin{tabular}{|l|l|l|l|l|l|}
\hline $\mathrm{Hg}^{2+}-1$ & $\begin{array}{l}\text { p-tert-butyl calix[4]crown } \\
\text { with imine units }\end{array}$ & 27.3 & $5.0 \times 10^{-5}-1.0 \times 10^{-1}$ & - & 271 \\
\hline $\mathrm{Hg}^{2+}-2$ & Pentathia-15-crown-5 & 32.1 & $2.51 \times 10^{-7}-1.0 \times 10^{-1}$ & - & 272 \\
\hline $\mathrm{Hg}^{2+}-3$ & $\begin{array}{l}\text { dibenzodiazathia-18- } \\
\text { crown-6-dione }\end{array}$ & 29 & $8.0 \times 10^{-6}-1.0 \times 10^{-2}$ & $\mathrm{Cd}^{2+} \mathrm{Pb}^{2+} \mathrm{K}^{+}$ & 273 \\
\hline $\mathrm{Hg}^{2+}-4$ & $\begin{array}{l}\text { hexathia-18-crown-6- } \\
\text { tetraone }\end{array}$ & $29.0 \pm 0.3$ & $4.0 \times 10^{-6}-1.0 \times 10^{-3}$ & - & 274 \\
\hline $\mathrm{I}_{3}{ }^{-1}-1$ & $\begin{array}{l}\text { Two different charge- } \\
\text { transfer complexes and } \\
\text { amino crown ether }\end{array}$ & -59 & $1.0 \times 10^{-5}-1.0 \times 10^{-1}$ & - & 275 \\
\hline $\mathrm{SCN}^{-}-1$ & $\begin{array}{l}\text { Cu(II)-1,8- } \\
\text { dimethyl-1,3,6,8,10,13- } \\
\text { hexaazacyclotetradecane } \\
\text { complex }\end{array}$ & -57.2 & $7.0 \times 10^{-6}-1.0 \times 10^{-1}$ & $\mathrm{ClO}_{4}^{-}$ & 276 \\
\hline $\mathrm{SCN}^{-}-2$ & $\begin{array}{l}\text { Ni(II)-azamacrocycle } \\
\text { complex }\end{array}$ & -57.8 & $1.0 \times 10^{-7}-1.0 \times 10^{-1}$ & - & 277 \\
\hline $\mathrm{SO}_{4}{ }^{2-}-1$ & $\begin{array}{l}2,5-\text { diphenyl-1,2,4,5- } \\
\text { tetraaza- } \\
\text { bicyclo[2.2.1]heptane }\end{array}$ & -28.8 & $9.0 \times 10^{-6}-1.0 \times 10^{-1}$ & - & 278 \\
\hline
\end{tabular}

Structures of some of the above ionophores are depicted in Figures 22 -26.

Figure 22. Some structures of crown ethers used as supramolecular ionophores in construction of the first group metal cations membrane sensors.

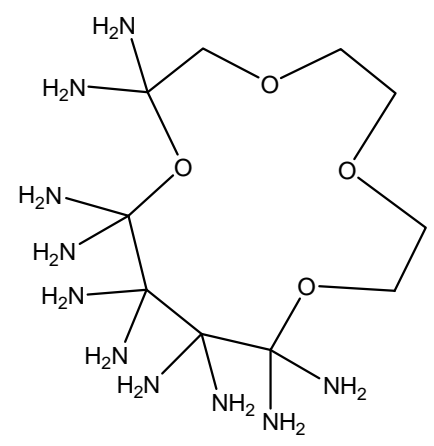

$\mathrm{Li}^{+}-1$

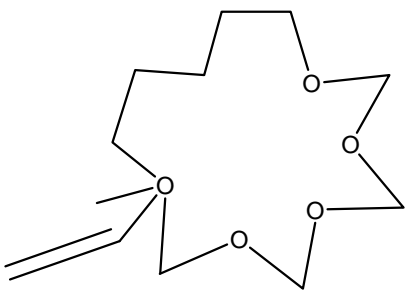

$\mathrm{Na}^{+}-5$

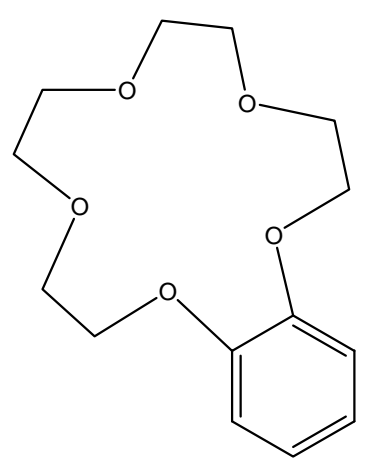


Figure 23. Some structures of crown ethers used as supramolecular ionophores in construction of the $\mathrm{Be}^{2+}$ membrane sensors.<smiles>c1ccc2c(c1)OCCOCCO2</smiles><smiles>O=[N+]([O-])c1ccc(NNc2ccc3c(c2)OCCOCCO3)c([N+](=O)[O-])c1</smiles>

$\mathrm{Be}^{2+}-1$

$\mathrm{Be}^{2+}-2$
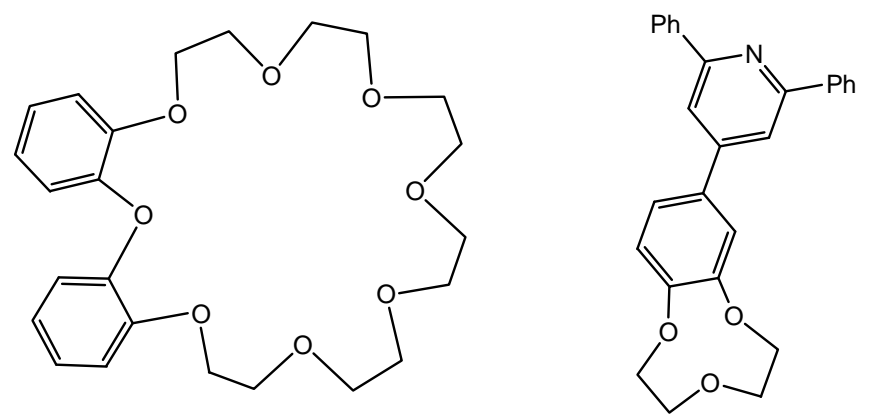

$\mathrm{Be}^{2+}-3$

$\mathrm{Be}^{2+}-5$

Figure 24. Some structures of crown ethers used as supramolecular ionophores in construction of the $\mathrm{Pb}^{2+}$ membrane sensors.
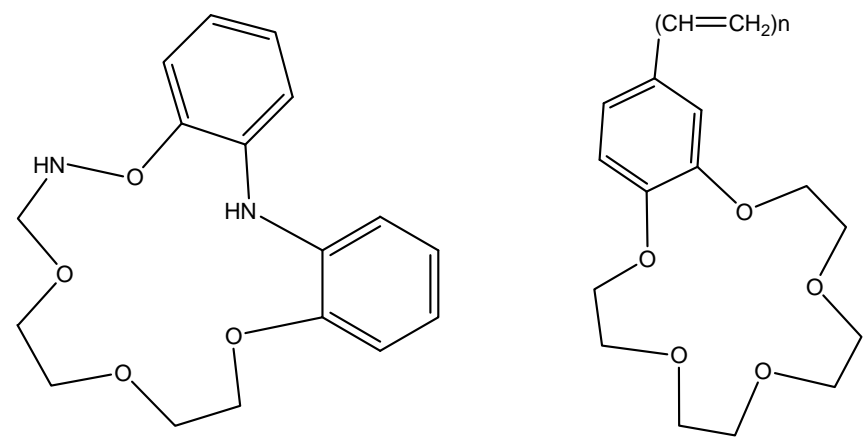

$\mathrm{Pb}^{2+}-2$

$\mathrm{Pb}^{2+}-3$

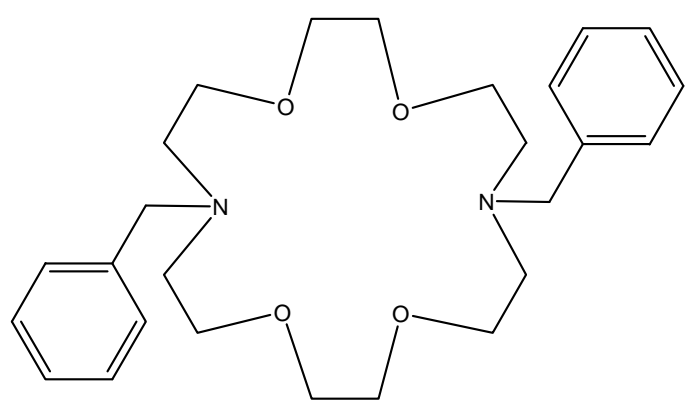


Figure 25. A structure of a crown ether used as supramolecular ionophore in the construction of the $\mathrm{Ag}^{+}$membrane sensors.

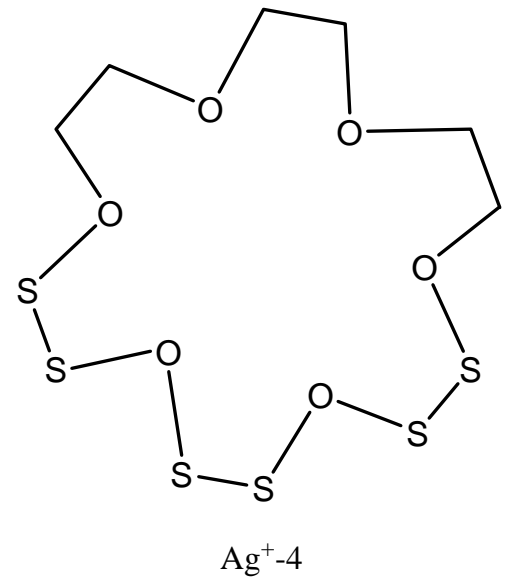

Figure 26. Some structures of crown ethers used as supramolecular ionophore in the construction of the $\mathrm{Hg}^{2+}$ membrane sensors.

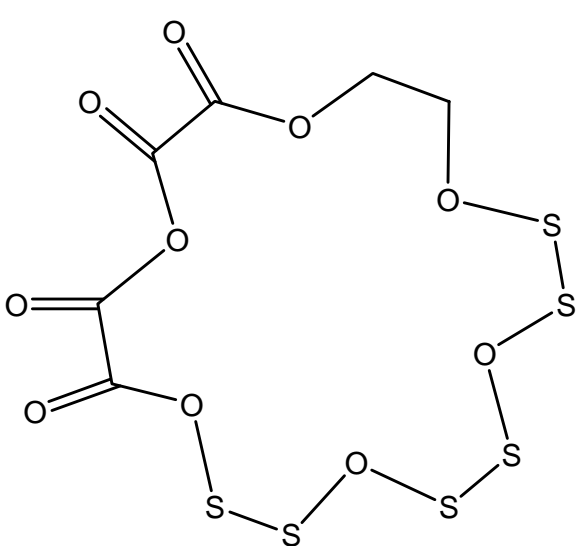

$\mathrm{Hg}^{2+}-4$<smiles>O=C(COCCONNOSC(=O)Oc1ccccc1Oc1ccccc1O)OCCO</smiles>

$\mathrm{Hg}^{2+}-3$

\section{Conclusions}

Ionophore incorporated PVC membrane sensors are well-established analytical tools routinely used for the selective and direct measurement of a wide variety of different ions in complex biological and environmental samples. The potentiometric sensors have some outstanding advantages including simple design and operation, wide linear dynamic range, relatively fast response and rational selectivity. The vital component of such plasticized PVC members is the ionophore involved, defining the selectivity of the electrodes complex formation. Molecular recognition causes the formation of many different supramolecules. Different types of supramolecules, like calixarenes, cyclodextrins, podands, have been used as a sensing material in construction of the ion selective sensors. Schiff's bases and crown ethers which feature in supramolecular chemistry can be used as sensing material in the construction of potentiometric ion selective electrodes. Up to now, more than 200 potentiometric membrane sensors based on Schiff's bases and crown ethers have been reported for cations and anions. 
In this review cation binding and anion complexes have been described and liquid membrane sensors based on Schiff's bases and crown ethers were discussed.

\section{References}

1. Werner, A. Coordination Chemistry, Zeitschr. Anorg. Chem. $1893,3,267$.

2. Behr, J.-P. (Ed.). The Lock and Key Principle. The State of the Art-100 Years On; Wiley: Chichester, 1994.

3. Katsuhiko, A.; Toyoki, K. Supramolecular Chemistry-Fundamentals and Applications Advanced Textbook. Springer-Verlag: Berlin Heidelberg, 2006.

4. Ganjali, M. R.; Norouzi, P.; Rezapour, M. Encyclopedia of Sensors, Volume 8, Potentiometric ion selective sensors. American Scientific Publishers (ASP): California, 2006.

5. Pick, J.; Tóth, K.; Vasàk, M.; Pungor, E.; Simon, W. Ion Selective Electrodes. Pungor, E.; Buzás, I. (Eds.); Akadémi aiKiadó: Budapest, 1973.

6. Fiedler, U.; Ruzicka, J. Selectrode. The universal ion selective electrode. Part VII. A valinomycin-based potassium electrode with nonporous polymer membrane and solid-state inner reference system. Anal. Chim. Acta 1973, 67, 179.

7. Horvai, G.; Graf, E.; Tóth, K.; Pungor, E.; Buck, R.P. Plasticized poly(vinyl chloride) properties and characteristics of valinomycin electrodes. 2. Low-frequency, surface-rate, and Warburg impedance characteristics Anal. Chem. 1986, 58, 2744.

8. Van den Berg, A.; Van der Wal, P.D.; Skowronska-Ptasinska, M.; Sudhölter, E.J.R.; Reinhoudt, D.N. Nature of anionic sites in plasticized poly(vinyl chloride) membranes. Anal. Chem. 1987, 59, 2827.

9. Lindner, E.; Gràf, E.; Nigreisz, Z.; Toth, K.; Pungor, E.; Buck, R.P. Responses of site-controlled, plasticized membrane electrodes. Anal. Chem. 1988, 60, 295.

10. Bühlmann, P.; Yajima, S.; Tohda, k.; Umezawa, Y. EMF response of neutral-carrier based ionsensitive field effect transistors with membranes free of ionic sites. Electrochim. Acta 1995, 40, 3021.

11. Lindner, E.; Cosofret, V.V.; Ufer, S.; Buck, R.P.; Kao, W.J.; Neuman ,M.R.; Anderson, J.M. Ionselective membranes with low plasticizer content-electroanalytical characterization and biocompatibility studies. J. Biomed. Mater. Res. 1994, 28, 591-601.

12. Wotring, V.J.; Prince, P.K.; Bachas, L.G. Evaluation of poly(vinylidene chloride) as a matrix for polymer membrane ion-selective electrodes. Analyst 1991, 116, 581-584.

13. Reinhoudt, D.N.; Engbersen, J.F.J.; Bròzka, Z.; Vlekkert, H.H.; Honig,G.W.N.; Holterman, H.A.J.; Verkerk, U.H. Development of durable $\mathrm{K}^{+}$-selective chemically-modified field-effect transistors with functionalized polysiloxane membranes. Anal. Chem. 1994, 66, 3618-3623

14. Ganjali, M.R.; Mizani, F.; Salavati-Niasari, M.; Javanbakht, M. Novel potentiometric membrane sensor for the determination of trace amounts of chromium (III) ions. Anal. Sci. 2003, 19, 235238.

15. Born, M.Z. Volumes and heats of hydration of ions. Physic 1920, 1, 45-48. 
16. Lindner, E.; Tóth, K.; Pungor, E.; Behm, F.; Oggfnfuss, P.; Welti, D.H.; Ammann, D.; Morf, W.E.; Pretsch, E.; Simon, W. Lead-selective neutral carrier based liquid membrane electrode. Anal. Chem. 1984, 56, 1127.

17. Morf, W.E.; Ammann, D.; Simon, W. Ion-selective electrodes based on neutral carriers. Chimia 1974, 28, 65-67.

18. Ammann, D. Ion-Selective Microelectrodes. Springer-Verlag: Berlin, 1986.

19. Ammann, D.; Pretsch, E.; Simon, W.; Lindner, E.; Bezegh, A.; Pungor, E. Lipophilic salts as membrane additives and their influence on the properties of macro- and micro-electrodes based on neutral carriers. Anal. Chim. Acta 1985, 171, 119.

20. Mristers, M.; Vandeberg, J.T.; Cassaretto, F.P.; Posvic, H.; Moore, C.E. Studies in the tetraarylborates: Part V. The influence of substituents on the stability of tetraarylborates. Anal. Chim. Acta 1970, 49, 481.

21. Nishida, H.; Takada, N.; Yoshimura, M.; Sonoda, T.; Kobayashi, H. Agent for Solvent-extraction of Cations. Bull. Chem. Soc. Jpn. 1984, 57, 2600.

22. Bakker, E.; Bühlmann, P.; Pretsch, E. Carrier-based ion-selective electrodes and bulk optodes. 1. General characteristics. Chem. Rev. 1997, 97, 3083-3132.

23. Schaller, U.; Bakker, E.; Spichiger, U.E.; Pretsch, E. Nitrite-selective microelectrodes. Talanta 1994, 41, 1001-1005.

24. Vanysek, P. Electrochemistry on Liquid/Liquid Interfaces. Springer: Berlin, Heidelberg, NewYork, 1985.

25. Hofmeister, F. On the understanding of the effects of salts, second report. On irregularities in the precipitating effect of salts and their relationship to their physical behavior, Arch. Exp. Pathol. Pharmakol. 1888, 24, 247.

26. Mi, Y.; Bakker, E. Determination of Complex Formation Constants of Lipophilic Neutral Ionophores in Solvent Polymeric Membranes with Segmented Sandwich Membranes. Anal. Chem. 1999, 71, 5279.

27. Qin, Y.; Mi,Y.; Bakker, E. Determination of complex formation constants of 18 neutral alkali and alkaline earth metal ionophores in poly(vinyl chloride) sensing membranes plasticized with bis(2-ethylhexyl)sebacate and o-nitrophenyloctylether. Anal. Chim. Acta 2000, 421, 207-220.

28. Morf, W.E. The Principles of Ion-Selective Electrodes and of Membrane Transport. Elsevier: New York, 1981.

29. Lindner, E.; Tóth, K.; Pungor, E. Dynamic Characteristics of Ion Selective Electrodes. CRC Press: Boca Raton, FL., 1988.

30. Lehn, J.M. Cryptates: macropolycyclic inclusion complexes. Pure Appl. Chem. 1977, 49, 857.

31. Lehn, J.M. Cryptates: inclusion complexes of macropolycyclic receptor molecules. Pure Appl. Chem. 1978, 50, 871.

32. Poonia, N.S.; Bajaj, A.V. Coordination chemistry of alkali and alkaline earth cations. Chem. Rev. 1979, 79, 389-445.

33. Izatt, R. Thermodynamic and kinetic data for cation-macrocycle interaction. Chem. Rev. 1985, 85, 271-339.

34. Tawarah, K.M.; Mizyed, S.A. A conductance study of the association of alkali cations with 1,13dibenzo-24-crown-8 in acetonitrile. J. Solut. Chem. 1989, 18, 387. 
35. Antonisse, M.M.G.; Reinhoudt, D.N. Potentiometric anion selective sensors. Electroanalysis 1999, 11, 1035-1048.

36. Marcus, Y. Ion solvation. Wiley: New York, 1985; p. 166.

37. Antonisse, M.M.G.; Reinhoudt, D.N. Neutral anion receptors: design and application. Chem. Commun. 1998, 443-448.

38. Schmidtchen, F.P.; Berger, M. Artificial organic host molecules for anions. Chem. Rev. 1997, 97, 1609-1646.

39. Ganjali, M.R.; Norouzi, P.; Faridbod, F.; Rezapour, M.; Pourjavid, M.R. One Decade of Research on Ion-Selective Electrodes in Iran (1996-2006), J. Iran. Chem. Soc. 2007, 4, 1-29.

40. Bühlmann, P.; Pretsch, E.; Bakker, E. Carrier-based ion-selective electrodes and bulk optodes. 2. Ionophores for potentiometric and optical sensors. Chem. Rev. 1998, 98, 1593-1698.

41. Saeed Shahrokhian, Ali Souri, Metalophthalocyanine complexes as ion-carriers in membraneselective electrodes for detection of thiosalicylic acid, Analytica Chimica Acta 518 (2004) 101108.

42. Zamani, H.A.; Rajabzadeh, Gh.; Ganjali, M.R.; Mola Khatami, S. Highly selective and sensitive copper(II) membranes sensors based on 6-methyl-4-(1-phenylmethylidene) amino-3- thioxo1,2,4-triazin-5-one as a new neutral ionophores, Electroanalysis, 2005,17, 2260-2265.

43. Debye, P.; Huckel, E. Theory of the Electrolyte. Phys. Z. 1928, 24, 305-325.

44. Zamani, H.A.; Abedini-Torghabeh, J.; Ganjali, M.R.; A highly selective and sensitive barium(II)-selective PVC membrane based on dimethyl 1-acetyl-8-oxo-2,8-dihydro-1hpyrazolo[5,1-a]isoindole-2,3-dicarboxylate, Electroanalysis, 2006, 18, 888.

45. Zamani, H.A.; Rajabzadeh, G.; Ganjali, M.R. Highly selective and sensitive chromium(III) membrane sensors based on 4-amino-3-hydrazino-6-methyl-1,2,4-triazin-5-one as a new neutral ionophores. Sens. Actuators. B, 2006, 119, 41-46.

46. Ganjali, M.R.; Rouhollahi, A.; Moghimi, A.; Shamsipur, M. Conductance study of alkali metal complexes with 4'-carboxy-benzo-24-crown-8 and 4'-amido-benzo-24-crown-8 in nitromethane, acetonitrile and dimethylformamide solutions. Pol. J. Chem. 1996, 70, 1172-1181.

47. Ganjali, M.R.; Zargazi, M.H.; Mohajeri, A. Thermodynamic study of the interaction between some recently synthesized benzo-substituted macrocyclic diamides with some pyridinium ion derivatives in acetonitrile solution. Pol. J.Chem. 2001, 75, 743-749.

48. Ganjali, M.R.; Rouhollahi, A.; Mardan, A.R.; Shamsipur, M. Thermodynamic study of the binding of hexathia-18-crown-6-tetraone with some transition and heavy metal ions in dimethyl sulfoxide solution, J. Chem. Soc. Faraday T. 1998, 94 , 1959-1962

49. Rouhollahi, A.; Ganjali, M.R.; Moghimi, A.; Buchanan, G.W.; Shamsipur, M. Synthesis of 4'carboxybenzo-30-crown-10 and a thermodynamic study of its complexes with thallium and alkali cations in acetonitrile solution. J. Incl. Phenom. Macro. 1999, 33, 361-376.

50. Pourghobadi, Z.; Seyyed-Majidi, F.; Daghighi-Asli, M.; Parsa, F.; Moghimi, A.; Ganjali, M.R.; Aghabozorg, H.; Shamsipur, M. Synthesis of a new triazine derived macrocycle and a thermodynamic study of its complexes with some transition and heavy metal ions in acetonitrile solution. Pol. J. Chem. 2000, 74, 837-846. 
51. Ganjali, M.R.; Khoshdan, N.; Hashemi, O.R.; Sajjadi, S.A.S. Thermodynamic study of some pyridinium ion derivatives with 18-crown-6, aza-18-crown-6 and 1,10-diaza-18-crown-6 in acetonitrile. Pol. J. Chem. 2000, 74, 1389-1398.

52. Shamsipur, M.; Ganjali, M.R. Complex formation of some anilinium ion derivatives with 18crown-6, 1,10-diaza-18-crown-6 and cryptand C222 in acetonitrile, dimethylformamide and their 1:1 mixture. J. Inclus. Phenom. Mol. 1997, 28, 315-323.

53. Ganjali, M.R.; Akbara, V.; Ghorbania, M.; Norouzia, P.; Ahmadi, A. Fluoride determination in some mouth wash preparations by a novel $\mathrm{La}$ (III) graphite coated membrane sensor based on amitraz, Anal. Chim. Acta 2005, 531,185-191.

54. Ganjali, M.R.; Norouzi, P.; Hatambeygi, N.; Salavati-Niasari, M. Anion recognition: Fabrication of a highly selective and sensitive HPO4 2-PVC sensor based on a oxo-molybdenum methylsalen. J. Braz. Chem. Soc. 2006, 17, 859-865.

55. Ganjali, M.R.; Naji, L.; Poursaberi, T.; Taghizadeh, M.; Pirelahi, H.; Yousefi, M.; Yeganeh-Faal, A.; Shamsipur, M. Novel sulfate ion-selective polymeric membrane electrode based on a derivative of pyrilium perchlorate, Talanta 2002, 58, 359-366.

56. Jabbari, A.; Shamsipur, M. Spectroscopic study of some alkali and alkaline earth complexes with ben20 crown ethers in ethanol solution. Spectrosc. Lett. 1993, 26, 1715-1724.

57. Ganjali, M.R.; Naji, L.; Poursaberi, T.; Taghizadeh, M.; Pirelahi, H.; Yousefi, M.; Yeganeh-Faal, A.; Shamsipur, M. Novel sulfate ion-selective polymeric membrane electrode based on a derivative of pyrilium perchlorate. Talanta 2002, 58, 359-366.

58. de Silva, A.P.; Sandanayake, K.R.A.S. J. Chem. Soc. Chem. Commun. 1989, 1183.

59. Ji, H.F.; Dabestani, R.; Brown, G.M.; Sachleben, R.A. A new highly selective calix[4]crown-6 fluorescent caesium probe. Chem. Commun. 2000, 833-834.

60. Ji, H.F.; Dabestani, R.; Brown, G.M.; Hettich, R.L. Spacer length effect on the photoinduced electron transfer fluorescent probe for alkali metal ions. Photochem. Photobiol. 1999, 69, 513516.

61. Karkhaneei, E.; Zebarjadian, M.H.; Shamsipur, M. ${ }^{23} \mathrm{Na}$ NMR Studies of Stoichiometry and Stability of Sodium Ion Complexes with Several Crown Ethers in Binary AcetonitrileDimethylformamide Mixtures, J. Incl. Phenom. Macro. 2006, 54, 309-313.

62. Kolthoff, I.M.; Lingane, J.J. Polarography, 2nd ed.; Interscience: New York, 1952.

63. Parham, H.; Shamsipur, M. Polarographic study of the interaction between heavy metal ions and some macrocyclic ligands in binary acetonitrile + water mixtures. J. Electroanal. Chem. 1991, 314, 71-80.

64. Crow, D.R. Polarography of Metal Complexes. Academic Press: New York, 1969.

65. Hojo, M.; Imai, Y. Bull. Chem. Soc. Jpn. 1983, 56, 1963.

66. Shamsipur, M.; Zolgharnein, J. Competitive Potentiometric Study of the Thermodynamics of Complexation of Some Transition and Heavy Metal Ions with Dibenzopyridino-18-crown-6 in Methanol Using $\mathrm{Ag}^{+}$Ion as a Probe. J. Incl. Phenom. Macro. 2001, 40, 41-44.

67. Egget, D. J. Computational Methods for the Determination of Formation Constants. Plenum Press: New York, 1985.

68. Møller, C.; Plesset, M.S. Note on an Approximation Treatment for Many-Electron Systems. Phys. Rev. 1934, 46, 618-622. 
69. Head-Gordon, M.; Pople, J.A.; Frisch, M. MP2 Energy Evaluation of Direct Methods J. Chem. Phys. Lett. 1988, 153, 503.

70. Sponer, J.; Berger, I.; S ¡pac¡kova, N.; Leszczynski, J.; Hobza, P. Aromatic base stacking in DNA: From ab initio calculations to molecular dynamics simulations. J. Biolmol. Struct. Dyn. 2000, 11, 383-407.

71. Chalasinski, G.; Szczesniak, M.M. Origins of structure and energetics of van-der-waals clusters from ab-initio calculations. Chem. Rev. 1994, 94, 1723-1765.

72. Frisch, M.J.; Trucks, G.W.; Schlegel, H.B.; Scuseria, G.E.; Robb, M.A.; Cheeseman, J.R.; Zakrzewski, V.G.; Montgomery, J.A.J.; Stratmann, R. E.; Burant, J.C.; Dapprich, S.; Millam, J.M.; Daniels, A.D.; Kudin, K.N.; Strain, M.C.; Farkas, O.; Tomasi, J.; Barone, V.; Cossi, M.; Cammi, R.; Mennucci, B.; Pomelli, C.; Adamo, C.; Clifford, S.; Ochterski, J.; Petersson, G.A.; Ayala, P.Y.; Cui, Q.; Morokuma, K.; Malick, D.K.; Rabuck, A.D.; Raghavachari, K.; Foresman, J.B.; Cioslowski, J.; Ortiz, J.V.; Baboul, A.G.; Stefanov, B.B.; Liu, G.; Liashenko, A.; Piskorz, P.; Komaromi, I.; Gomperts, R.; Martin, R.L.; Fox, D.J.; Keith, T.; AlLaham, M.A.; Peng, C.Y.; Nanayakkara, A.; Gonzalez,C.; Challacombe, M.; Gill, P.M.W.; Johnson, B.; Chen, W.; Wong, M.W.; Andres, J.L.; Gonzalez, C.; Head-Gordon, M.; Replogle, E.S.; Pople, J.A. Gaussian 03, Revision A.7; Gaussian Inc.: Pittsburgh, PA, 2003.

73. Ganjali, M.R, Norouzi, P.; Rezapour, M.; Faridbod, F.; Pourjavid, M.R.; Supramolecular Based Membrane Sensors, Sensors 2006, 6, 1018-1086.

74. Cragg, P.J. A Practical Guide to Supramolecular Chemistry. John Wiley \& Sons: Chichester, 2005.

75. Faridbod, F.; Ganjali, M.R.; Dinarvand, R.; Norouzi, P. Ion recognition: Application of symmetric and asymmetric Schiff bases and their complexes for the fabrication of cationic and anionic membrane sensors to determine ions in real samples. Comb. Chem. High T. Scr. 2007, 10, 527-546.

76. Gupta, V.K.; Singh, A. K.; Gupta, B. A cerium(III) selective polyvinyl chloride membrane sensor based on a Schiff base complex of N,N'-bis[2-(salicylideneamino)ethyl]ethane-1,2diamine. Anal. Chim. Acta 2006, 575, 198-204.

77. Singh, A.K.; Gupta, V.K.; Gupta, B. Chromium(III) selective membrane sensors based on Schiff bases as chelating ionophores. Anal. Chim. Acta 2007, 585, 171-178.

78. Cozzi, P.G. Metal-Salen Schiff base complexes in catalysis: practical aspects. Chem. Soc. Rev. 2004, 33, 410-421.

79. Shemirani, F.; Mirroshandel, A.A.; Salavati-Niasari, M.; Kozani, R.R. Silica gel coated with Schiff's base: Synthesis and application as an adsorbent for cadmium, copper, zinc, and nickel determination after preconcentration by flame atomic absorption spectrometry. J. Anal. Chem. 2004, 59, 228-233.

80. Alizadeh, N.; Ershad, S.; Naeimi, H.; Sharghi, H.; Shamsipur, M. Synthesis of a new naphtholderivative salen and spectrophotometric study of the thermodynamics and kinetics of its complexation with copper(II) ion in binary dimethylsulfoxide-acetonitrile mixtures. Pol. J. Chem. 1999, 73, 915-925. 
81. Shamsipur, M.; Yousefi, M.; Hoseini, M.; Ganjali, M. R.; Sharghi, H.; Naeimi, H. A schiff base complex of Zn(II) as a neutral carrier for highly selective PVC membrane sensors for the sulfate ion. Anal. Chem. 2001, 73, 2869-2874.

82. Abbaspour, A.; Esmaeilbeig, A.R.; Jarrahpour, A.A.; Khajeh, B.; Kia, R. Aluminium(III)selective electrode based on a newly synthesized tetradentate Schiff base. Talanta 2002, 58, 397403.

83. Arvand, M.; Moghimi, A.M.; Afshari, A.; Mahmoodi, N. Potentiometric membrane sensor based on 6-(4-nitrophenyl)-2,4-diphenyl-3,5-diaza-bicyclo[3.1.0] hex-2-ene for detection of Sn(II) in real samples. Anal. Chim. Acta 2006, 579, 102-108.

84. Arida, H.A.; El-Reefy, S.A.; El-Saied, A.M. A new lead (II)-selective PVC-coated graphite rod electrode based on a Schiff base complex. Anal. Sci. 2003, 19, 687-690.

85. Ardakany, M.M.; Ensafi, A.A.; Naeimi, H.; Dastanpour, A.; Shamlli, A. Highly selective lead(II) coated-wire electrode based on a new Schiff base. Sens. Actuators. B 2003, 96, 441-445.

86. Ardakany, M.M.; Ensafi, A.A.; Naeimi, H.; Dastanpour, A.; Shamlli, A. Coated, wire-based, new Schiff base potentiometric sensor for lead(II) ion. Russ. J. Electrochem. 2003, 39, 269-273.

87. Ardakany, M.M., Pourhakak, P., Salavati-Niasari, M. Bis(2-hydroxyacetophenone)ethylenediimine as a neutral carrier in a coated-wire membrane electrode for lead(II). Anal. Sci. 2006, 22, 865-870.

88. Jeong, T.; Jeong, D.C.; Lee, H.K.; Jeon, S. Lead(II)-selective polymeric electrode using a Schiff base complex of N,N'-bis-thiophene-2-ylmethylene-ethane-1,2-diamine as an ion carrier. Bull. Korean Chem. Soc. 2005, 26, 1219-1224.

89. Jeong, T.; Lee, H.K.; Jeong, D.C.; Jeon, S. A lead (II)-selective PVC membrane based on a Schiff base complex of N,N'-bis(salicylidene)-2,6-pyridinediamine. Talanta 2005, 65, 543-548.

90. Gupta, V.K.; Jain, A.K.; Kumar, P. PVC-based membranes of N,N '-dibenzyl-1,4,10,13-tetraoxa7,16-diazacyclooctadecane as Pb(II)-selective sensor. Sens. Actuators B 2006, 120, 259-265.

91. Ganjali, M.R.; Daftari, A.; Norouzi, P.; Salavati-Niasari, M. Novel Y (III) PVC based membrane microelectrode based on a new S-N Schiff's base. Anal. Lett. 2003, 36, 1511-1522.

92. Ganjali, M.R.; Kiani-Anbouhi, R.; Shamsipur, M.; Poursaberi, T.; Salavati-Niasari, M.; Talebpour, Z.; Emami, M. Novel potentiometric PVC-membrane and coated graphite sensors for lanthanum(III). Electroanalysis 2004, 16, 1002-1008.

93. Ganjali, M.R.; Qomi, M.; Daftari, A.; Norouzi, P.; Salavati-Niasari, M.; Rabbani, M. Novel lanthanum(III) membrane sensor based on a new N-S Schiff's base. Sens. Actuators B 2004, 98, 92.

94. Gupta, V.K.; Singh, A.K.; Gupta, B. A cerium(III) selective polyvinyl chloride membrane sensor based on a Schiff base complex of N,N'-bis[2-(salicylideneamino)ethyl]ethane-1,2-diamine. Anal. Chim. Acta 2006, 575, 198-204.

95. Ganjali, M.R.; Emami, M.; Rezapour, M.; Shamsipur, M.; Maddah, B.; Salavati-Niasari, M.; Hosseini, M.; Talebpoui, Z. Novel gadolinium poly(vinyl chloride) membrane sensor based on a new S-N Schiff's base. Anal. Chim. Acta 2003, 495, 51-59.

96. Ganjali, M.R.; Rezapour, M.; Norouzi, P.; Salavati-Niasari, M. A new pentadentate S-N Schiffs' base as a novel lonophore in construction of a novel Gd(III) membrane sensor. Electroanalysis 2005, 17, 2032-2036. 
97. Ganjali, M.R.; Ghesmi, A.; Hosseini, M.; Pourjavid, M.R.; Rezapour, M.; Shamsipur, M.; Salavati-Niasari, M. Novel terbium(III) sensor based on a new bis-pyrrolidene Schiff's base. Sens. Actuators B 2005, 105, 334-339.

98. Ganjali, M.R.; Ravanshad, J.; Hosseini, M.; Salavati-Niasari, M.; Pourjavid, M. R.; Baezzat, M.R. Novel Dy(III) sensor based on a new bis-pyrrolidene Schiff's base. Electroanalysis 2004, 16, 1771-1776.

99. Ganjali, M.R.; Dodangeh, M.; Ghorbani, H.; Norouzi, P.; Adib, M. PPb level monitoring of Dy(III) ions by a highly sensitive and selective Dy(III) sensor based on a new asymmetrical Schiff's base. Anal. Lett. 2006, 39, 495-506.

100. Ganjali M.R.; Norouzi P.; Adib M.; Ahmadalinezhad A. A novel Holmium(III) membrane sensor based on N-(1-thien-2-ylmethylene)-1,3-benzothiazol-2-amine. Anal. Lett. 2006, 39, 1075-1086.

101. Ganjali, M. R.; Tamaddon, A.; Norouzi, P.; Adib, M. Novel Lu(III) membrane sensor based on a new asymmetrically S-N Schiff's base. Sens. Actuators B, 2006, 120, 194-199.

102. Shamsipur, M.; Saeidi, M.; Yari, A.; Yaganeh-Faal, A.; Mashhadizadeh, M. H.; Azimi, G.; Naeimi, H.; Sharghi, H. $\mathrm{UO}_{2}{ }^{2+}$ ion-selective membrane electrode based on a naphthol-derivative Schiff's base 2,2'-[1,2-ethandiyl bis(nitriloethylidene)]bis(1-naphthalene). Bull. Korean Chem. Soc.; 2004, 25, 629-633.

103. Ganjali, M.R.; Emami, M.; Salavati-Niasari, M.; Yousefi, M. Determination of trace amounts of $\mathrm{Cr}(\mathrm{III})$ in presence of $\mathrm{Cr}(\mathrm{VI})$ by a novel potentiometric membrane sensor based on a new tridentate S,N,O Schiff's base. Anal. Lett. 2003, 36, 2735-2747.

104. Ganjali, M.R.; Mizani, F.; Salavati-Niasari, M.; Javanbakht, M. Novel potentiometric membrane sensor for the determination of trace amounts of chromium(III) ions. Anal. Sci. 2003, 19, 235 238.

105. Shamsipur, M.; Soleymanpour, A.; Akhond, M.; Sharghi, H.; Sarvari, M.H. Highly selective chromium(III) PVC-membrane electrodes based on some recently synthesized Schiff's bases. Electroanalysis 2005, 17, 776-782.

106. Ganjali, M.R.; Norouzi, P.; Faridbod, F.; Ghorbani, M.; Adib, M. Highly selective and sensitive chromium(III) membrane sensors based on a new tridentate Schiff's base. Anal. Chim. Acta 2006, 569, 35-41.

107. Singh, A.K.; Gupta, V.K.; Gupta, B. Chromium(III) selective membrane sensors based on Schiff bases as chelating ionophores. Anal. Chim. Acta 2007, 585, 171-178.

108. Gupta, V.K.; Jain, A. K.; Maheshwari, G. Manganese (II) selective PVC based membrane sensor using a Schiff base. Talanta 2007, 72, 49-53.

109. Mashhadizadeh, M.H.; Shoaei, I. S.; Monadi, N. A novel ion selective membrane potentiometric sensor for direct determination of Fe(III) in the presence of Fe(II). Talanta 2004, 64, 1048-1052.

110. Mashhadizadeh, M.H.; Sheikhshoaie, I. $\mathrm{Co}^{2+}$-selective membrane electrode based on the Schiff base NADS. Anal. Bioanal. Chem. 2003, 375, 708-712.

111. Kumar, K.G.; Poduval, R.; Augustine, P.; John, S.; Saraswathyamma, B. A PVC plasticized sensor for Ni (II) ion based on a simple ethylenediamine derivative. Anal. Sci. 2006, 22, 13331337. 
112. Mashhadizadeh, M.H.; Sheikhshoaie, I.; Saeid-Nia, S. Nickel(II)-selective membrane potentiometric sensor using a recently synthesized Schiff base as neutral carrier. Sens. Actuators B 2003, 94, 241-246.

113. Jain, A.K.; Gupta, V.K.; Ganeshpure, P.A.; Raisoni, J.R. Ni(II)-selective ion sensors of salen type Schiff base chelates . Anal. Chim. Acta 2005, 553, 177-184.

114. Kumar, K.G.; Poduval, R.; John, S.; Augustine, P. A PVC plasticized membrane sensor for nickel ions. Mikrochim. Acta 2006, 156, 283-287.

115. Pleniceanu, M.; Isvoranu, M.; Spinu, C. Liquid membrane ion-selective electrodes for potentiometric dosage of coper and nickel. J. Serb. Chem. Soc. 2005, 70, 269-276.

116. Pleniceanu, M.; Isvoranu, M.; Spinu, C. Electroanalytical applications of some mixed complex combinations with Schiff base. Asian J. Chem. 2005, 17, 2129-2136.

117. Pleniceanu, M.; Isvoranu, M.; Spinu, C. New electrochemical sensors used for potentiometric determination of copper and nickel. J. Indian Chem. Soc. 2002, 79, 884-886.

118. Alizadeh, N.; Ershad, S.; Naeimi, H.; Sharghi, H.; Shamsipur, M. Copper (II)-selective membrane electrode based on a recently synthesized naphthol-derivative Schiff's base. Fresenius J. Anal. Chem. 1999, 365, 511-515.

119. Ganjali, M.R.; Poursaberi, T.; Babaei, L.H.A.; Rouhani, S.; Yousefi, M.; Kargar-Razi, M.; Moghimi, A.; Aghabozorg, H.; Shamsipur, M. Highly selective and sensitive copper(II) membrane coated graphite electrode based on a recently synthesized Schiff's base. Anal. Chim. Acta 2001, 440, 81-87.

120. Poursaberi, T.; Hajiagha-Babaei, L.; Yousefi, M.; Rouhani, S.; Shamsipur, M.; Kargar-Razi, M.; Moghimi, A.; Aghabozorg, H.; Ganjali, M.R. The synthesis of a new thiophene-derivative Schiff's base and its use in preparation of copper-ion selective electrodes. Electroanalysis 2001, 13, 1513-1517.

121. Ganjali, M.R.; Emami, M.; Salavati-Niasari, M. Novel copper(II)-selective sensor based on a new hexadentates Schiff's base. Bull. Korean Chem. Soc. 2002, 23, 1394-1398.

122. Sadeghi, S.; Eslahi, M.; Naseri, M. A.; Naeimi, H.; Sharghi, H.; Shameli, A. Copper ion selective membrane electrodes based on some Schiff base derivatives. Electroanalysis 2003, 15, 13271333.

123. Fakhari, A.R.; Raji, T.A.; Naeimi, H. Copper-selective PVC membrane electrodes based on salens as carriers. Sens. Actuators B 2005, 104, 317-323.

124. Jeong, D.C.; Lee, H.K.; Jeon, S. Highly copper(II)-selective PVC membrane based on a Schiff base complex of N,N '-bis-pyridin-2-ylmethylene-naphthalene-1,8-diamine as an ionophore. Bull. Korean Chem. Soc. 2006, 27, 1593-1596.

125. Xie, N.; Chen, Y. Design and synthesis of a selective chemosensor for $\mathrm{Zn}^{2+}$. Chin. J. Chem. 2006, 24, 1800-1803.

126. Gholivand, M.B.; Rahimi-Nasrabadi, M.; Ganjali, M.R.; Salavati-Niasari, M. Highly selective and sensitive copper membrane electrode based on a new synthesized Schiff base. Talanta 2007, 73, 553-560.

127. Ganjali, M.R.; Golmohammadi, M.; Yousefi, M.; Norouzi, P.; Salavati-Niasari, M.; Javanbakht, M. Novel PVC-based copper(II) membrane sensor based on 2-(1'-(4'-(1'-hydroxy-2"-naphthyl)methyleneamino)butyl iminomethyl)-1-naphthol. Anal. Sci. 2003, 19, 223-227. 
128. Singh, L.P.; and Bhatnagar, J.M. Copper (II) selective electrochemical sensor based on Schiff Base complexes. Talanta 2004, 64, 313-319.

129. Norouzi, P.; Ganjali, M.R.; Faridbod, F.; Salavati-Niasari, M. Determination of copper in black, red pepper and the waste water samples by a highly selective sensitive $\mathrm{Cu}(\mathrm{II})$ microelectrode based on a new hexadentates Schiff,s base. Bull. Korean Chem. Soc. 2006, 27, 1439.

130. Gupta, K.C.; D'Arc, M.J. Performance evaluation of copper ion selective electrode based on cyanocopolymers. Sens. Actuators B 2000, 62, 171-176.

131. Alizadeh, N.; Ershad, S.; Naeimi, H.; Sharghi, H.; Shamsipur, M. Copper(II)-selective membrane electrode based on a recently synthesized naphthol-derivative Schiff's base. Fresenius J. Anal. Chem. 1999, 365, 511-515.

132. Gupta, V.K.; Agarwal, S.; Jakob, A.; Lang, H. A zinc-selective electrode based on N,N 'bis(acetylacetone)ethylenediimine. Sens. Actuators B 2006, 114, 812-818.

133. Mahajan, R.K.; Kumar, M.; Sharma, V.; Kaur, I. Silver (I) ion-selective membrane based on Schiff base-p-tert-butylcalix[4]arene. Analyst 2001, 126, 505-507.

134. Ueda, M.; Sakaki, N.; Moriuchi-Kawakami, T.; Shibutani, Y. Potentiometric performance of a dioxime-type Schiff base as a silver-ion recognizable material. Bunseki Kagaku 2001, 50, 619625.

135. Mahajan, R.K.; Kaur, I.; Sharma, V.; Kumar, M. Sensor for silver (I) ion based on Schiff-base-ptertbutylcalix[4] arene. Sensors 2002, 2, 417-423.

136. Demirel, A.; Dogan, A.; Akkus, G.; Yilmaz, M.; Kilic, E. Silver(I)-selective PVC membrane potentiometric sensor based on a recently synthesized calix[4]arene. Electroanalysis 2006, 18, 1019-1027.

137. Mahajan, R.K.; Kaur, I.; Kumar, M. Silver ion-selective electrodes employing Schiff base p-tertbutyl calix[4]arene derivatives as neutral carriers. Sens. Actuators B 2003, 91, 26-31.

138. Mashhadizadeh, M.H.; Mostafavi, A.; Allah-Abadi, H.; Sheikhshoai, I. New Schiff base modified carbon paste and coated wire PVC membrane electrode for silver ion. Sens. Actuators B 2006, 113, 930-936.

139. Demirel, A.; Dogan, A.; Akkus, G.; Yilmaz, M.; Kilic, E. Silver(I)-selective PVC membrane potentiometric sensor based on a recently synthesized calix[4]arene. Electroanalysis 2006, 18, 1019-1027.

140. Singh, A.K.; Saxena, P. Silver(I)-selective electrode based on [Bz(2)Oxo(4)(18)dieneS(4)] tetrathia macrocyclic carrier. Anal. Bioanal. Chem. 2006, 385, 90-95.

141. Mashhadizadeh, M.H.; Sheikhshoaie, I.; Saeid-Nia, S. Asymmetrical Schiff bases as carriers in PVC membrane electrodes for cadmium (II) ions. Electroanalysis 2005, 17, 648-654.

142. Gupta, V.K.; Singh, A.K.; Gupta, B. Schiff bases as cadmium(II) selective ionophores in polymeric membrane electrodes. Anal. Chim. Acta 2007, 583, 340-348.

143. Gismera, M.J.; Hueso, D.; Procopio, J.R.; Sevilla, A.T. Ion-selective carbon paste electrode based on tetraethyl thiuram disulfide for copper(II) and mercury(II). Anal. Chim. Acta 2004, 524, 347-353.

144. Xu, L.; Yuan, R.; Chai.; Y.Q. Mercury(II) ion potentiometric sensor based on a sulfur Schiff's base 1-(2-hydroxy-1,2-diphenylethylidene)thiosemicarbazide as ionophore. Chem. Lett. 2005, $34,440-441$. 
145. Mashhadizadeh, M.H.; Sheikhshoaie, I. Mercury(II) ion-selective polymeric membrane sensor based on a recently synthesized Schiff base. Talanta 2003, 60, 73-80.

146. Saleh, M.B.; Soliman, E.M.; Gaber, A.A.A.; Ahmed, S.A. A novel Hg(II) PVC membrane sensor based on simple ionophore ethylenediamine bis-thiophenecarboxaldehyde. Anal. Lett. 2006, 39, 659-673.

147. Mashhadizadeh, M.H.; Talakesh, M.; Peste, M.; Momeni, A.; Hamidian, H.; Majum, M. A novel modified carbon paste electrode for potentiometric determination of mercury(II) ion. Electroanalysis 2006, 18, 2174-2179.

148. Ganjali, M.R.; Norouzi, P.; Alizadeh, T.; Salavati-Niasari, M. Synthesis of a new hexadendates Schiff's base and its application in the fabrication of a highly selective mercury(II) sensor. Bull. Korean Chem. Soc. 2007, 28, 68-72.

149. Dai, J.Y.; Chai, Y.Q.; Yuan, R.; An, L.X.; Liu, Y.; Zhong, X.; Tang, D.P. Tricoordinate Schiff base copper(II) complex as neutral carrier for highly selective thiocyanate electrode. Anal. Lett. 2005, 38, 389-400.

150. Bühlmann, P.; Yahya, L.; Enderes, R. Ion-selective electrodes for thiocyanate based on the dinuclear Zinc(II) complex of a Bis-N,O-bidentate Schiff base. Electroanalysis 2004, 16, 973978.

151. Jyo, A.; Egawa, H. Effect of membrane matrices on performances of a thiocyanate ion-selective electrode based on the (5,10,15,20-tetraphenyl-porphyrinato)manganese(III) anion carrier. Anal. Sci. 1992, 8, 823-827.

152. Ganjali, M.R.; Poursaberi, T.; Basiripour, F.; Salavati-Niasari, M.; Yousefi, M.; Shamsipur, M. Highly selective thiocyanate poly(vinyl chloride) membrane electrode based on a cadmiumSchiff's base complex. Fresenius J. Anal. Chem. 2001, 370, 1091-1095.

153. Ardakani, M.M.; Salvati-Niassari, M.; Sadeghi, A. Novel selective thiocyanate PVC membrane electrode based on new Schiff base complex of 2.2-[(1,3-dimethyl-1,3propanediylidene)dinitrilo]bis-benzenethiolato cadmium(II). New J. Chem. 2004, 28, 595-599.

154. Ardakani, M.M.; Sadeghi, A.; Salavati-Niasari, M. Highly selective thiocyanate membrane electrode based on butane-2,3-dione bis(salicylhydrazonato)zinc(II) complex. Talanta 2005, 66, 837-843.

155. Shamsipur, M.; Yousefi, M.; Hosseini, M.; Ganjali, M.R.; Sharghi, H.; Naeimi, H. A schiff base complex of $\mathrm{Zn}(\mathrm{II})$ as a neutral carrier for highly selective PVC membrane sensors for the sulfate ion. Anal. Chem. 2001, 73, 2869-2874.

156. Ganjali, M.R.; Norouzi, P.; Golmohammadi, M.; Mizani, F.; Poursaberi, T.; Salavati-Niasari, M.; Shamsipur, M.; Hosseini, M., Javanbakht, M. Ann. Chim (Rome), 2003, 93,679.

157. Ganjali, M.R.; Rezapour, M.; Pourjavid, M.R.; Salavati-Niasari, M.; Poursaberi, T. A novel potentiometric membrane sensor for quick determination of trace amount of SO42- based on a zinc-Schiff's base. Anal. Lett. 2003, 36, 881-894.

158. Soleymanpour, A.; Asl, E.H.; Nasseri, M.A. Chemically modified carbon paste electrode for determination of sulfate ion by potentiometric method. Electroanalysis 2006, 18, 1598-1604.

159. Mitchell-Koch, J.T.; Malinowska, E.; and Meyerhoff, M.E. Gallium(III)-Schiff base complexes as novel ionophores for fluoride selective polymeric membrane electrodes. Electroanalysis 2005, 17, 1347-1353. 
160. Ganjali, M.R.; Pourjavid, M.R.; Rezapour, M.; Poursaberi, T.; Daftari, A.; Salavati-Niasari, M. Ruthenium(III) Schiff's base complex as novel chloride selective membrane sensor. Electroanalysis 2004, 16, 922-927.

161. Kumar, K.G.; John, K.S.; Indira, C.J. A chloride ion-selective potentiometric sensor based on a polymeric schiff base complex. Indian J. Chem. Technol. 2006, 13, 13-16.

162. Shamsipur, M.; Soleymanpour, A.; Akhond, M.; Sharghi, H.; Naseri, M.A. Iodide-selective carbon paste electrodes based on recently synthesized Schiff base complexes of Fe(III). Anal. Chim. Acta 2001, 450, 37-44.

163. Farhadi, K.; Maleki, R.; Yamchi, R. H.; Sharghi, H.; Shamsipur, M. [Tetrakis(4-N,Ndimethylaminobenzene)porphyrinato]-manganese(III) acetate as a novel carrier for a selective iodide PVC membrane electrode. Anal. Sci. 2004, 20, 805-809.

164. Ganjali, M.R.; Emami, M.; Javanbakht, M.; Salavati-Niasari, M.; Shamsipur, M.; Yousefi, M. Novel triiodide ion-selective polymeric membrane sensor based on mercury-salen. Sens. Actuators B 2005, 105, 127-131.

165. Sadeghi, S.; Fathi, F.; Ali Esmaeili, A.; Naeimi, H. Novel triiodide ion-selective polymeric membrane electrodes based on some transition metal-Schiff base complexes. Sens. Actuators $B$ 2006, 114, 928-935.

166. Ganjali, M.R.; Norouzi, P.; Qomi, M.; Salavati-Niasari, M. Charge-transfer complex between iodine and a new Schiff's base as anion-carrier in construction of a highly selective triiodide PVC-based membrane electrode. Can. J. Anal. Sci. Spect. 2006, 51, 108-116.

167. Ganjali, M.R.; Moghaddamb, M.R.; Norouzi, P.; Shirvani-Arani, S.; Daneshgar, P.; Adib, M.; Sobhi, H.R. Highly selective and sensitive triiodide PVC-based membrane electrode based on a new charge transfer complex of 2-(((2-(((E)-1-(2-hydroxyphenyl) methylidine) amino) phenyl) imino) methyl) phenol for nano-level monitoring of triiodide. Anal. Lett. 2006, 39, 683-695.

168. Sadeghi, S.; Gafarzadeh, A.; Naseri, M.A.; Sharghi, H. Triiodide-selective polymeric membrane electrodes based on Schiff base complexes of $\mathrm{Cu}(\mathrm{II})$ and Fe(III). Sens. Actuators B 2004, 98, 174-179.

169. Sadeghi, S.; Fathi, F.; Ali Esmaeili, A.; Naeimi, H. Novel triiodide ion-selective polymeric membrane electrodes based on some transition metal-Schiff base complexes. Sens. Actuators $B$ 2006, 114, 928-935.

170. Chai, Y.Q.; Jiang, F.; Yuan, R.; Xu, L.; Xu, W.J. A highly selective salicylate electrode based on Schiff base complexes of cobalt(III). Anal. Lett. 2003, 36, 2379-2392.

171. Ardakani, M.M.; Jamshidpoor, M.; Naeimi, H.; Heidarnezhad, A. Determination of salicylate by selective poly(vinylchloride) membrane electrode based on N,N '-1,4-butylene bis(3-methyl salicylidene iminato) copper(II). Bull. Korean Chem. Soc. 2006, 27, 1127-1132.

172. Amini, M.K.; Khorasani, J.H.; Khaloo, S.S.; Tangestaninejad, S. Cobalt(II) salophen-modified carbon-paste electrode for potentiometric and voltammetric determination of cysteine. Anal. Biochem., 2003, 320, 32-38.

173. Larrow, J.F.; Jacobsen, E.N. (R,R)-N,N'-Bis(3,5-Di-tert-Butylsalicylidene)-1,2-Cyclohexane diamino Manganese(III) Chloride, A Highly Enantioselective Epoxidation Catalyst, Org. Synth. Coll. 2004, 10, 96. 
174. Ganjali, M.R.; Rezapour, M.; Pourjavid, M.R.; Salavati-Niasari, M. Highly selective PVCmembrane electrodes based on Co(II)-Salen for determination of nitrite ion, Anal. Sci. 2003, 19, 1127-1131.

175. Ganjali, M.R.; Mizani, F.; Emami, M.; Salavati-Niasari, M.; Shamsipur, M.; Yousefi, M.; Javanbakht, M. Novel liquid membrane electrode for selective determination of monohydrogenphosphate. Electroanalysis 2003, 15, 139-144.

176. Ganjali, M.R.; Norouzi P.; Hatambeygi, N.; Salavati-Niasari, M. Anion recognition: fabrication of a highly selective and sensitive HPO42- PVC sensor based on a oxo-molybdenum methylsalen. J. Braz. Chem. Soc. 2006, 17, 859-865.

177. Ganjali, M.R.; Norouzi, P.; Faridbod, F.; Ghorbani, M.; Adib, M. Highly selective and sensitive chromium(III) membrane sensors based on a new tridentate Schiff's base. Anal. Chim. Acta 2006, 569, 35-41.

178. Ganjali, M.R.; Norouzi, P., Golmohammadi, M.; Rezapour, M.; Salavati- Niasari, M. Novel bromide PVC-based membrane sensor based on iron(III)-salen. Electroanalysis 2004, 16, 910914.

179. Shamsipur, M.; Sadeghi, S.; Naeimi, H.; Sharghi, H. Iodide ion-selective PVC membrane electrode based on a recently synthesized salen-Mn(II) complex. Pol. J. Chem. 2000, 74, 231238.

180. Ganjali, M.R.; Poursaberi, T.; Hosseini, M.; Salavati-Niasari, M.; Yousefi, M.; Shamsipur, M. Highly selective iodide membrane electrode based on a cerium salen. Anal. Sci. 2002, 18, 289292.

181. Ganjali, M.R.; Emami, M.; Javanbakht, M.; Salavati-Niasari, M.; Shamsipur, M.; Yousefi, M. Novel triiodide ion-selective polymeric membrane sensor based on mercury-salen. Sens. Actuators B 2005, 105, 127-131.

182. Gholivand, M.B.; Ahmadi, F.; Rafiee, E. A novel Al(III)-selective electrochemical sensor based on N,N'-bis(salicylidene)-1,2-phenylenediamine complexes. Electroanalysis 2006, 18, 16201626.

183. Ganjali, M.R., Shirvani-Arani, S., Norouzi, P., Rezapour, M., and Salavati-Niasari, M. Novel nitrite membrane sensor based on cobalt(II) salophen for selective monitoring of nitrite ions in biological samples, Mikrochim. Acta 2004, 146, 35-41.

184. Wroblewski, W.; Brzozka, Z.; Rudkevich, D.M.; Reinhoudt, D.N. Nitrite-selective ISE based on uranyl salophen derivatives. Sens. Actuators B 1996, 37, 151-155.

185. Wroblewski, W., Wojciechowski, K., Dybko, A., Brzozka, Z., Egberink, R.J.M., Snellink-Ruel, B.H.M., and Reinhoudt, D.N. Uranyl salophenes as ionophores for phosphate-selective electrodes. Sens. Actuators B 2000, 68, 313-318.

186. Ganjali, M.R., Mizani, F., and Salavati-Niasari, M. Novel monohydrogenphosphate sensor based on vanadyl salophen. Anal. Chim. Acta 2003, 481, 85-90.

187. Ion, I.; Ion, A.C.; Barbu, L. Potentiometric determination of fluoride in groundwaters. Rev. Roum. Chim. 2005, 50, 407-412.

188. Zare, H.R., Memarzadeh, F., Gorji, A., and Ardakani, M.M. Iodide-selective membrane electrode based on salophen complex of cobalt (III). J. Braz. Chem. Soc. 2005, 16, 571-577. 
189. Shamsipur, M.; Ershad, S.; Samadi, N.; Esmaeilbeig, A.R.; Kia, R.; Abdolmaleki, A. Polymeric membrane lanthanum(III)-selective electrode based on N,N'-adipylbis(5-plenylazo salicylaldehyde hydrazone). Electroanalysis 2005, 17, 1828-1834.

190. Ganjali, M.R.; Matloobi, P.; Ghorbani, M.; Norouzi, P.; Salavati-Niasari, M. La (III) selective membrane sensor based on a new N-N Schiff's base. Bull. Korean Chem. Soc. 2005, 26, 38-42.

191. Ganjali, M. R.; Gholivand, M.B.; Maddah, B.; Salavati-Niasari, M.; Ahmadi, F. Synthesis of a new octadentates Schiff's base and its application in construction of a highly selective and sensitive lanthanum (III) membrane sensor. Sensor Lett. 2006, 4, 356-363.

192. Ganjali, M.R.; Norouzi, P.; Nasrin Yousefian, N.; Faridbod, F.; Adib, M. Sub-micro molar monitoring of La3+ by a novel lanthanum PVC-based membrane sensor based on 3-hydroxy-N '(pyridin-2-ylmethylene)-2-naphthohydrazide. Bull. Korean Chem. Soc. 2006, 27, 1581-1586.

193. Ganjali, M.R.; Norouzi, P.; Alizadeh, T.; Adib, M. Application of 8-amino-N-(2hydroxybenzylidene)naphthyl amine as a neutral ionophore in the construction of a lanthanum ion-selective sensor. Anal. Chim. Acta 2006, 576, 275-282.

194. Zamani, H.A.; Ganjali, M.R.; Norouzi, P.; Adib, M.; Aceedy M. Synthesis of N'-(1-pyridin-2ylmethylene)-2-furohydrazide and its application in construction of a highly selective PVC-based membrane sensor for La(III) ions. Anal. Sci. 2006, 22, 943-948.

195. Ganjali, M.R.; Mirnaghi, F.S.; Norouzi, P.; Adib, M. Novel Pr(III)-selective membrane sensor based on a new hydrazide derivative. Sens. Actuators B 2006, 115, 374-378.

196. Norouzi, P.; Ganjali, M.R.; Ahmadalinezhad, A.; Adib, M. Novel neodymium(III) membrane sensor based on N-(2-furylmethylene)pyridine-2,6-diamine. J. Braz. Chem. Soc. 2006, 17, 13091315.

197. Ganjali, M.R.; Ahmadalinezhad, A.; Norouzi, P.; Adib, M. Nd(III)-PVC membrane sensor based on 2-\{[(6-aminopyridin-2-yl)imino]methyl $\}$-phenol. J. Appl. Electrochem. 2006, 36, 931-936.

198. Zamani, H.A.; Ganjali, M.R.; Adib, M. Fabrication of a new samarium(III) ion-selective electrode based on 3-\{[2-oxo-1(2H)-acenaphthylenyliden]amino\}-2-thioxo-1,3-thiazolidin-4one. J. Braz. Chem. Soc. 2007, 18, 215-222.

199. Ganjali, M.R.; Norouzi, P.; Daftari, A.; Faridbod, F.; Salavati-Niasari, M. Fabrication of a highly selective $\mathrm{Eu}(\mathrm{III})$ membrane sensor based on a new S-N hexadentates schiff's base. Sens. Actuators B 2007, 120, 673-678.

200. Ganjali, M.R.; Rezapour, M.; Rasoolipour, S.; Norouzi, P.; Adib, M. Application of Pyridine-2carbaldehyde-2-(4-methyl-1,3-benzo thiazol-2-yl)hydrazone as a Neutral Ionophore in the Construction of a Novel Er(III) Sensor. J. Braz. Chem. Soc. 2007, 18, 352-358.

201. Ganjali, M.R.; Faridbod, F.; Norouzi, P.; Adib, M. A novel Er(III) sensor based on a new hydrazone for the monitoring of Er(III) ions, Sen. Actuators B ,2006,120, 119-124.

202. Faridbod, F.; Gangali, M.R.; Larijani, B.; Norouzi, P.; Riahi ,S.; Mirnaghi, F.S. Lanthanide Recognition: an Asymetric Erbium Microsensor Based on a Hydrazone Derivative, Sensors 2007, 7, 3119.

203. Ganjali, M.R.; Rasoolipour, S.; Rezapour, M.; Norouzi, P.; Adib, M. Synthesis of thiophene-2carbaldehyde-(7-methyl-1,3-benzothiazol-2-yl)hydrazone and its application as an ionophore in the construction of a novel thulium (III) selective membrane sensor. Electrochem. Commun. 2005, 7, 989-994. 
204. Ganjali M.R.; Norouzi P.; Tamaddon A., Adib M. Nano-level monitoring of ytterbium(III) by a novel ytterbium(III) membrane sensor based on 3-hydroxy-N '-[(2-hydroxyphenyl) methylene]2-naphthohydrazide. Sens. Actuators B 2006, 114, 855-860.

205. Ganjali, M. R.; Norouzi, P.; Alizadeh, T.; Salavati-Niasari, M. Synthesis of a new hexadendates Schiff's base and its application in the fabrication of a highly selective mercury(II) sensor. Bull. Korean Chem. Soc. 2007, 28, 68-72.

206. Ganjali, M.R.; Norouzi, P.; Shirvani-Arani, S.; Salavati-Niasari, M. Novel triiodide PVC-based membrane sensor based on a charge transfer complex of iodine and bis(2hydroxyacetophenone)butane-2,3-dihydrazone. Bull. Korean Chem. Soc. 2005, 26, 1738-1742.

207. Ganjali, M.R.; Shirvani-Arani, S.; Bidhendi, G.N.; Norouzi, P.; Salavati-Niasari, M. Highly selective and sensitive triiodide PVC-membrane electrode based on a new charge-transfer complex of bis(2,4-dimethoxybenzaidehyde)butane-2,3-dihydrazone with iodine. J. Chin. Chem. Soc. 2006, 53, 275-281.

208. Ganjali, M.R.; Norouzi, P.; Shirvani-Arani, S.; Salavati-Niasari, M. Novel triiodide PVC-based membrane sensor based on a charge transfer complex of iodine and bis(2hydroxyacetophenone)butane-2,3-dihydrazone. Bull. Korean Chem. Soc. 2005, 26, 1738-1742.

209. Weber E., Supramolecular Chemistry II-Host Design and Molecular Recognition, SpringerVerlag Berlin Heidelberg, 1995.

210. Lehn, J. M.; Sauvage, J. P. 1971, Cation selectivities of alkali and alkaline-earth cryptates Chem. Commun. 440.

211. Kobiro, K.; Tobe, Y.; Watanabe, K.; Yamada, H.; Suzuki, K. Highly selective lithium ion electrode based on decalino-14-Crown-4. Anal. Lett. 1993, 26, 49-54.

212. Jung, S.O.; Park, S.S.; Kim, B.G.; Kim, J.S. Lithium ion-selective electrode based on TNF-based 16-Crown-4 derivatives. Bull. Korean Chem. Soc. 1995, 16, 197-199.

213. Cretin, M.; Fabry, P. Detection and selectivity properties of $\mathrm{Li}^{+}$-ion-selective electrodes based on Nasicon-type ceramics. Anal. Chim. Acta 1997, 354, 291-299.

214. Kang, Y.R.; Lee, K.M.; Nam, H.; Cha, G.S.; Jung, S.O.; Kim, J.S. Lithium ion-selective electrodes employing tetrahydrofuran-based 16-crown-4 derivatives as neutral carriers. Analyst 1997,122, 1445-1450.

215. Shibata, Y.; Maruizumi, T.; MiyagiI, H. Characteristics of sodium ion- selective electrodes based on neutral carriers and their application to analysis of physiological fluids. Nippon Kagaku Kaishi 1992, 9, 961-967.

216. Lukyanenko, N.G.; Titova, N.Y.; Karpinchik, O.S.; Melnik, O.T. Sodium- Selective Electrodes Based On PVC Membranes Containing Bis[(3N+1)-Crown-N]. Ether Derivatives. Anal. Chim. Acta 1992, 259,145-148.

217. Yamamoto, H.; Ueda, K.; Suenaga, H.; Sakaki, T.; Shinkai, S. Exploitation of $\mathrm{Na}^{+}$-selective electrodes for protein solutions from crown-bridged calix[4]quinones. Chem. Lett. 1996, 1, 3940.

218. Tavakkoli, N. Sodium ion-selective membrane electrode based on dibenzopyridino-18-crown-6. Bull. Korean Chem. Soc. 2004, 25, 1474-1476.

219. Chandra, S.; Lang, H. A new sodium ion selective electrode based on novel silacrown ether. Sens. Actuators B 2006, 114, 849-854. 
220. Ganjali, M.R.; Moghimi, A.; Buchanan, G.W.; Shamsipur, M. The synthesis of styrene/4'-vinylbenzo-24-crown-8 copolymer and its use in potassium-ion selective electrodes. J. Inclus. Phenom. Mol. Rec. Chem. 1998, 30, 29-43.

221. Xia, Z.R.; Badr, I.H.A.; Plummer, S.L.; Cullen, L.; Bachas, L.G. Synthesis and evaluation of a bis(crown ether) ionophore with a conformationally constrained bridge in ion-selective electrodes. Anal. Sci. 1998, 14, 169-173.

222. Hyun, M.H.; Piao, M.H.; Cho, Y.J.; Shim, Y.B. Ionophores in rubidium ion-selective membrane electrodes. Electroanalysis 2004, 16, 1785-1790.

223. Shamsipur, M.; Alizadeh, K.; Hosseini, M.; Mousavi, M.F.; Ganjali, M.R. PVC membrane and coated graphite potentiometric sensors based on dibenzo-21-crown-7 for selective determination of rubidium ions,Anal. Lett. 2005, 38, 573-588.

224. Kang, Y.R.; Oh, H.J.; Lee, K.M.; Cha, G.S.; Nam, H.; Paek, K.; Ihm, H. Potentiometric characteristics of ion-selective electrodes based on upper-rim calix[4]crown neutral carrier. Bull. Korean Chem. Soc. 1998, 19, 207-211.

225. Kim, J.S.; Ohki, A.; Ueki, R.; Ishizuka, T.; Shimotashiro, T.; Maeda, S. Cesium- ion selective electrodes based on calix[4]arene dibenzocrown ethers. Talanta 1999, 48, 705-710.

226. Choi, Y.; Kim, H.; Lee, J.K.; Lee, S.H.; Lim, H.B.; Kim, J.S. Cesium ion-selective electrodes based on 1,3-alternate thiacalix[4]biscrown-6,6. Talanta 2004, 64, 975-980.

227. Ganjali, M.R.; Moghimi, A.; Shamsipur, M. Beryllium-selective membrane electrode based on benzo-9-crown-3. Anal. Chem. 1998, 70, 5259-5263.

228. Ganjali, M.R.; Daftari, A.; Rastegar, M.F.; Moghimi, A. Novel beryllium membrane sensor based on 2,4-dinitrophenylhydrazinebenzo-9-crown-3 coated graphite. Anal. Lett. 2003, 36, 317328.

229. Ganjali, M.R.; Daftari, A.; Faal-Rastegar, M.; Moghimi, A. Novel potentiometric sensor for monitoring beryllium based on naphto-9-crown-3. Anal. Sci. 2003, 19, 353-356.

230. Ganjali, M.R.; Ghorbani, M.; Norouzi, P.; Daftari, A.; Faal-Rastegar, M.; Moghimi, A. Nano levels detection of beryllium by a novel beryllium PVC-based membrane sensor based on 2,3,5,6,8,9-hexahydro-1,4,7,10-benzotetraoxacyclododecine-12-carbaldehyde-12-(2,4-dinitrophenyl) hy. Sens. Actuators B 2004, 100, 315-319.

231. Ganjali, M.R.; Rahimi-Nasrabadi, M.; Maddah, B.; Moghimi, A.; Faal-Rastegar, M.; Borhany, S.; Namazian, M. Sub-micro level monitoring of Beryllium ions with a novel beryllium sensor based on 2,6-diphenyl-4-benzo-9-crown-3- pyridine. Talanta 2004, 63, 899-906.

232. Ganjali, M.R.; Norouzi, P.; Faridbod, F.; Sepehrifard, A.; Ghandi, M.; Moghimi, A. Monitoring of beryllium(II) ions by use of a novel beryllium(II) membrane sensor, based on 2, 3, 5, 6, 8, 9hexahydronaphto [2,3-b][1, 4, 7, 10] tetraoxacyclo dodecine, Can. J. Anal. Sci. Spect. 2007, 52, 46-56.

233. Ganjali, M.R.; Daftari, A.; Pourjavid, M.R.; Rastegar, M.F.; Moghimi, A. Novel $\mathrm{Be}(\mathrm{II})$ membrane electrode-based on a derivative of benzo-9-crown-3, Main group met. chem. 2002, 25, 669-676.

234. Ganjali, M.R.; Akbar, V.; Norouzi, P.; Moghimi, A. Sepehrifard A, Be(II) graphite coated membrane sensor based on a recently synthesized benzo-9-crown-3 derivative, Electroanalysis 2005,17 , 895-900 . 
235. Gupta, V.K.; Chandra, S.; Mangla, R. Magnesium-selective electrodes. Sens. Actuators B 2002, 86, 235-241.

236. Gupta, V.K.; Jain, A.K.; Khurana, U.; Singh, L.P. PVC-based neutral carrier and organic exchanger membranes as sensors for the determination of $\mathrm{Ba}^{2+}$ and $\mathrm{Sr}^{2+}$. Sens. Actuators B 1999, 55, 201-211.

237. Shamsipur, M.; Rouhani, S.; Shaghi, H.; Ganjali, M.R.; Eshghi, H. Strontium-selective membrane electrodes based on some recently synthesized benzo-substituted macrocyclic diamides, Anal. Chem. 1999, 71, 4938-4943.

238. Abdulla, N.I.; Al-Haider, A.M.; Al-Joboury.; M.I.; Nassory, N.S. Construction and characterization of indium liquid ion selective electrodes based on crown ethers in a PVC matrix membrane. Turish J. Chem. 2005, 29, 687-696.

239. Khayatian, G.; Shariati, S.; Salimi, A. Thallium (I)-selective membrane potentiometric sensor based on dibenzyldiaza-18-crown-6. Bull. Korean Chem. Soc. 2003, 24, 421-425.

240. Aghaie, H.; Giahi, A.; Monajjemi, M.; Arvand, A.; Nafissi, G.H.; Aghaie, M. Tin(II)-selective membrane potentiometric sensor using a crown ether as neutral carrier. Sens. Actuators B 2005, 107, 756-761.

241. Sheen, S.R.; Shih, J.S. Lead (II) ion-selective electrodes based on crown ethers. Analyst 1992, 117, 1691-1695.

242. Pouretedal, H.R.; Keshavarz, M.H. Lead (H)-selective electrode based on dibenzodiaza-15crown-4. Asian J. Chem. 2004, 16, 1319-1326.

243. Ganjali, M.R.; Roubollahi, A.; Mardan, A.R.; Hamzeloo, M.; Mogimi, A.; Shamsipur, M. Lead ion-selective electrode based on 4 '-vinylbenzo-l5-crown-5 homopolymer . Microchim. J. 1998, 60, 122-133.

244. Yang, X.H.; Kumar, N.; Chi, H.; Hibbert, D.B.; Alexander, P.W. Lead-selective membrane electrodes based on dithiophenediazacrown ether derivatives. Electroanalysis 1997, 9, 549-553.

245. Ardakani, M.M.; Kashani, M.K.; Salavati-Niasari, M.; Ensafi, A.A. Lead ion- selective electrode prepared by sol-gel and PVC membrane techniques. Sens. Actuators B 2005, 107, 438-445.

246. Shamsipur, M.; Ganjali, M.R.; Rouhollahi, A. Lead-selective membrane potentiometric sensor based on an 18-membered thiacrown derivative, Anal. Sci. 2001, 17, 935-938.

247. Ganjali, M.R.; Hosseini, M.; Basiripour, F.; Javanbakht, M.; Hashemi, O.R.; Rastegar, M.F.; Shamsipur, M.; Buchanen, G.W. Novel coated-graphite membrane sensor based on N,N'dimethylcyanodiaza-18-crown-6 for the determination of ultra-trace amounts of lead, anal. Chim .Acta 2002, 464, 181-186.

248. Gupta, V.K.; Jain, S.; Chandra, S. Chemical sensor for lanthanum (III) determination using azacrown as ionophore in poly(vinyl chloride) matrix. Anal. Chim. Acta 2003, 486,199-207.

249. Shamsipur, M.; Yousefi, M.; Hosseini, M.; Ganjali, M.R. PVC-based 1,3,5-trithiane coated graphit electrode for determination of ceriume(III) ions, Anal. Lett. 2001, 34, 2249-2261.

250. Akl, M.A.; Ghoneim, A.K.; Abd El-Aziz, M.H. Novel plastic chromium (III)-ion selective electrodes based on different ionophoric species and plasticizing solvent mediators. Electroanalysis 2006, 18, 299-306.

251. Ekmekci, G.; Uzun, D.; Somer, G.; Kalayci, S. A novel iron (III) selective membrane electrode based on benzo-18-crown-6 crown ether and its applications. J. Membr. Sci. 2007, 288, 36-40. 
252. Shamsipur, M.; Poursaberi, T.; Rouhani, S.; Niknam, K.; Sharghi, H.; Ganjali, M.R,; Cobalt(II)selective membrane electrode based on a recently synthesized benzo-substituted macrocyclic diamide, Anal. Sci. 2001,17, 1049-1054.

253. Shamsipur, M.; Rouhani, S.; Poursaberi, T.; Ganjali, M.R.; Sharghi, H.; Niknam, K. Cobalt(II)selective coated graphite PVC-membrane electrode based on a recently synthesized dibenzopyridino-substituted macrocyclic diamide, Electroanalysis 2002,14,729-735.

254. Shamsipur, M.; Kazemi, S.Y. A PVC-based dibenzodiaza-15-crown-4 membrane potentiometric sensor for Ni (II). Electroanalysis 2000, 12, 1472-1475.

255. Shamsipur, M.; Javanbakht, M.; Mousavi, M.F.; Ganjali, M.R.; Lippolis, V.; Garau, A.; Tei, L. Copper(II)-selective membrane electrodes based on some recently synthesized mixed azathioether crowns containing a 1,10-phenanthroline sub-unit. Talanta 2001, 55, 1047-1054.

256. Shamsipur, M.; Rouhani, S.; Ganjali, M.R.; Eshghi, H.; Sharghi, H.Copper(II)-selective membrane electrode based on a recently synthesized macrocyclic diamide. Microchim. J. 1999, 63, 202-210.

257. Park, S.S.; Jung, S.O.; Kim, S.M.; Kim, J.S. Lipophilic pyrrole-based tetraazacrown ether as neutral carrier for silver ion-selective electrode. Bull. Korean Chem. Soc. 1996, 17, 405-407.

258. Goldcamp, M.J.; Ashley, K.; Edison, S.E.; Pretty, J.; Shumaker, J. A bis-oxime derivative of diaza-18-crown-6 as an ionophore for silver ion. Electroanalysis 2005, 17, 1015-1018.

259. Mashhadizadeh, M.H.; Shamsipur, M. Silver(I)-selective membrane electrode based on hexathia18-crown-6. Anal. Chim. Acta 1999, 381, 111-116.

260. Shamsipur, M.; Javanbakht, M.; Ganjali, M.R.; Mousavi, M.F.; Lippolis, V.; Garau, A. Mixed aza-thioether crowns containing a 1,10-phenanthroline sub-unit as neutral ionophores for silver ion. Electroanalysis 2002, 14, 1691-1698.

261. Chen, L.X.; He, X.W.; Zhang, H.Y.; Liu, Y.; Hu, X.B.; Sheng, Y. Selective electrode for silver based on polymer membranes containing exocyclic chalcogen atoms calix[4]arene and crown ether. Anal. Lett. 2001, 34, 2237-2248.

262. Demirel, A.; Dogan, A.; Akkus, G.; Yilmaz, M.; Kilic, E. Silver(I)-selective PVC membrane potentiometric sensor based on a recently synthesized calix[4]arene. Electroanalysis 2006, 18, 1019-1027.

263. Shamsipur, M.; Javanbakht, M.; Ganjali, M.R.; Mousavi, M.F.; Lippolis, V.; Garau, A. Mixed aza-thioether crowns containing a 1,10-phenanthroline sub-unit as neutral ionophores for silver ion. Electroanalysis 2002, 14, 1691-1698.

264. Pouretedal, H.R.; Shamsipur, M. A PVC-based cryptand C2(B)22 membrane potentiometric sensor for zinc(II). Fresenius J. Anal. Chem. 1998, 362, 415-418.

265. Gupta, V.K.; Al Khayat, M.; Minocha, A.; and Kumar, P. Zinc(II)-selective sensors based on dibenzo-24-crown-8 in PVC matrix. Anal. Chim. Acta 2005, 532, 153-158.

266. Shamsipur, M.; Rouhani, S.; Ganjali, M.R,; Sharghi, H.; Eshghi, H. Zinc-selective membrane potentiometric sensor based on a recently synthesized benzo-substituted macrocyclic diamide, Sens. Actuators B 1999, 59, 30-34.

267. Gupta, V.K.; Jain, A.K.; and Kumar, P. PVC-based membranes of dicyclohexano-24-crown-8 as Cd(II) selective sensor. Electrochim. Acta 2006, 52, 736-741. 
268. Abbas, M.N.; Zahran, E. Novel solid-state cadmium ion-selective electrodes based on its tetraiodo- and tetrabromo-ion pairs with cetylpyridinium. J. Electroanal. Chem. 2005, 576, 205-213.

269. Singh, A.K.; Saxena, P.; Singh, R. New cadmium(II)-selective electrode based on a tetraazacyclohexadeca macrocyclic ionophore. Anal. Sci. 2005, 21, 179-181.

270. Gupta, K.C.; D'Arc, M.J. Cadmium ion-selective electrode based on cyanocopolymer. Electroanalysis 2000, 12, 1408-1413.

271. Mahajan, R.K.; Kaur, R.; Kaur, I.; Sharma, V.; Kumar, M. Mercury(II) ion- selective electrodes based on p-tert-butyl calix[4]crowns with imine units. Anal. Sci. 2004, 20, 811-814.

272. Gupta, V.K.; Jain, S.; Khurana, U. A PVC-based pentathia-15-crown-5 membrane potentiometric sensor for mercury(II). Electroanalysis 1997, 9, 478-480.

273. Javanbakht, M.; Ganjali, M.R.; Eshghi, H.; Sharghi, H.; Shamsipur, M. Mercury(II) ion-selective electrode based on dibenzodiazathia-18-crown-6-dione. Electroanalysis 1999, 11, 81-84.

274. Fakhari, A.R.; Ganjali M.R.; Shamsipur M.; PVC-based hexathia-18-crown-6-tetraone sensor for mercury(II) ions. Anal Chem. 1997, 69, 3693-3696.

275. Sadeghi, S.; Dashti, G.R. Triiodide PVC membrane electrodes based on charge-transfer complexes. Anal. Chem. 2002, 74, 2591-2595.

276. Poursaberi, T.; Salavati-Niassari, M.; Khodabakhsh, S.; Hajiagha-Babaei, L.; Shamsipur, M.; Yousefi, M.; Rouhani, S.; Ganjali, M.R. A selective membrane electrode for thiocyanate ion based on a copper-1,8-dimethyl-1,3,6,8,10,13-azacyclotetradecane complex as ionophore. Anal. Lett. 2001, 34, 2621-2632.

277. Ganjali, M.R.; Yousefi, M.; Javanbakht M.; Poursaberi, T.; Salavati-Niasari, M.; HajiaghaBabaei, L.; Latifi, L.; Shamsipur, M. Determination of SCN- in urine and saliva of smokers and non-smokers by $\mathrm{SCN}^{-}$-selective polymeric membrane containing a nickel(II)-azamacrocycle complex coated on a graphite electrode. Anal. Sci. 2002, 18, 887-892.

278. Shamsipur, M.; Yousefi, M.; Ganjali, M.R.; Poursaberi, T.; Faal-Rastgar, Majid. Highly selective sulfate PVC-membrane electrode based on 2,5-diphenyl-1,2,4,5-tetraaza-bicyclo[2.2.1]heptane as a neutral carrier, Sens. Actuators B 2002, 82 , 105-110.

2008 by MDPI (http://www.mdpi.org). Reproduction is permitted for noncommercial purposes. 